\title{
United Kingdom: 2003 Article IV Consultation-Staff Report; Public Information Notice on the Executive Board Discussion; and Statement by the Executive Director for the United Kingdom
}

Under Article IV of the IMF's Articles of Agreement, the IMF holds bilateral discussions with members, usually every year. In the context of the 2003 Article IV consultation with the United Kingdom, the following documents have been released and are included in this package:

- the staff report for the 2003 Article IV consultation, prepared by a staff team of the IMF, following discussions that ended on December 18, 2003, with the officials of the United Kingdom on economic developments and policies. Based on information available at the time of these discussions, the staff report was completed on February 13, 2004. The views expressed in the staff report are those of the staff team and do not necessarily reflect the views of the Executive Board of the IMF.

- $\quad$ a Public Information Notice (PIN) summarizing the views of the Executive Board as expressed during its March 3, 2004 discussion of the staff report that concluded the Article IV consultation.

- $\quad$ a statement by the Executive Director for the United Kingdom.

The document(s) listed below have been or will be separately released.

\section{Selected Issues Paper}

The policy of publication of staff reports and other documents allows for the deletion of market-sensitive information.

To assist the IMF in evaluating the publication policy, reader comments are invited and may be sent by e-mail to publicationpolicy@imf.org.

$$
\begin{gathered}
\text { Copies of this report are available to the public from } \\
\text { International Monetary Fund • Publication Services } \\
70019^{\text {th }} \text { Street, N.W. • Washington, D.C. } 20431 \\
\text { Telephone: (202) 623-7430 • Telefax: (202) 623-7201 } \\
\text { E-mail: publications@imf.org • Internet: http://www.imf.org }
\end{gathered}
$$

Price: $\$ 15.00$ a copy

\section{International Monetary Fund Washington, D.C.}





\title{
INTERNATIONAL MONETARY FUND
}

\section{UNITED KINGDOM}

\section{Staff Report for the 2003 Article IV Consultation}

Prepared by the Staff Representatives for the 2003 Article IV Consultation with the United Kingdom

\author{
Approved by Michael Deppler and John Hicklin
}

February 13, 2004

- $\quad$ Article IV Consultation discussions were held in London during December 3-18, 2003. The mission comprised Messrs. Cottarelli (Head), Chadha, Escolano, Ms. Honjo, and Ms. Koeva (all EUR). Mr. Scholar, Executive Director, and Mr. Kelmanson (OED) attended the meetings. Staff met with the Chancellor of the Exchequer, the Governor of the Bank of England (BoE), the Chairman of the Financial Services Authority (FSA), other senior government officials, members of the Monetary Policy Committee (MPC) of the BoE, representatives of employers' and employees' organizations, and financial institutions.

- At the conclusion of last year's consultation in February 2003, Directors welcomed the growth performance of the UK economy during the slowdown, sustained by the timely easing of monetary and fiscal stances. However, they called for vigilance regarding the risks posed by high household debt and house prices. Directors also saw downside risks to the authorities' revenue projections and called for expenditure restraint to lower over time the structural fiscal deficit and avoid inefficiency in spending. Directors welcomed the conclusions of the Financial Sector Assessment Program (FSAP) indicating the financial supervision framework was strong and banks were highly profitable and capitalized, but called for sustained vigilance of the insurance industry.

- The authorities' policies continue to be broadly in line with Director's appraisals in earlier consultations. The macroeconomic policy and financial supervision frameworks remain at the forefront internationally and are consistent with Fund recommendations. The authorities, however, have not yet responded to the call for moderating the growth of public spending, in spite of fiscal outturns that have remained weaker than targeted.

- $\quad$ The United Kingdom has accepted the obligations of Article VIII, Sections 2, 3, and 4. The exchange system is free of restrictions on payments and transfers for current international transactions (Appendix II).

- $\quad$ The United Kingdom has subscribed to the Special Data Dissemination Standard, and data provision is adequate for surveillance (Appendix III).

- The authorities released the mission's concluding statement and have agreed to the publication of the staff report. 
Contents Page

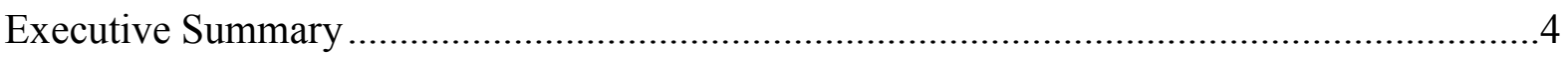

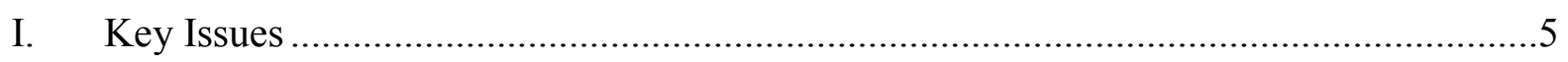

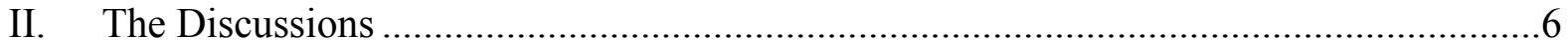

A. Recent Development and Outlook ...........................................................6

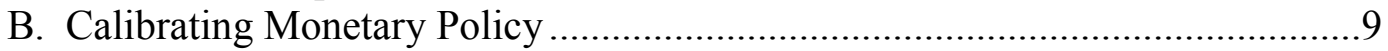

C. Does the Fiscal Correction Require New Measures? .....................................12

D. Assessment of the Five Tests for EMU Entry ............................................ 16

E. Structural and Financial Sector Issues.......................................................... 18

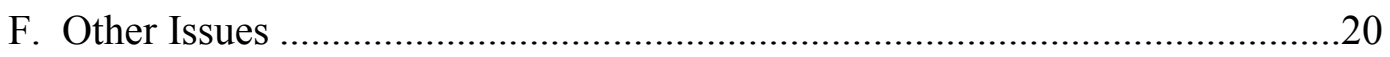

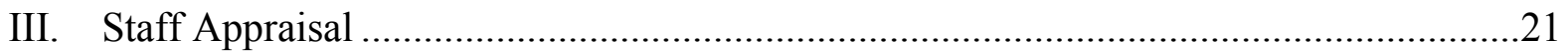

\section{Text Boxes}

1. Household Balance Sheets ...................................................................................

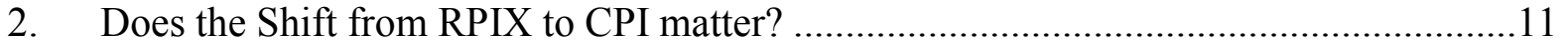

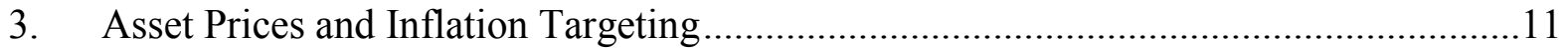

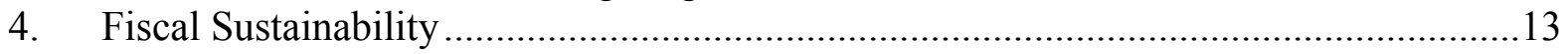

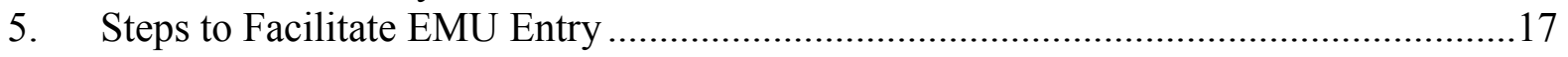

Figures

1. The Economy Has Weathered the Global Slowdown Well .........................................25

2. Financial Markets are Pricing in an Upswing.......................................................26

3. Household Balance Sheets are Important for Consumption ........................................27

4. The Labor Market Has Remarkably Resilient During the Slowdown ..........................28

5. The Housing Market Remains Robust.....................................................................29

6. Inflation Has Remained Close to Target.....................................................................30

7. The Monetary Policy Stance Has Been Expansionary ............................................ 31

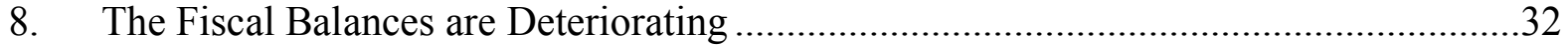

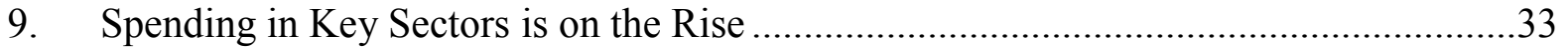

Tables

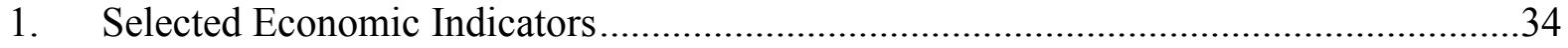

2. Quarterly Growth Rates and Contribution to Growth..............................................35

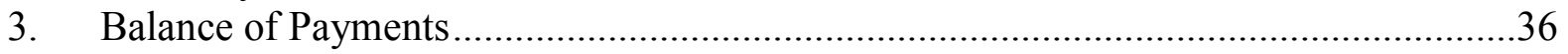

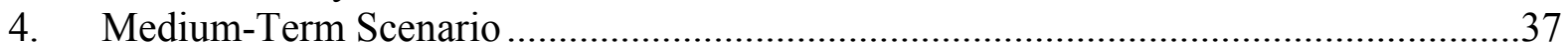

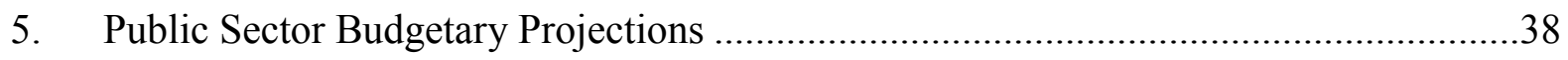




\section{Appendices}

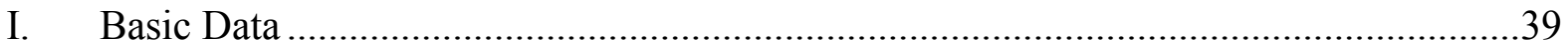

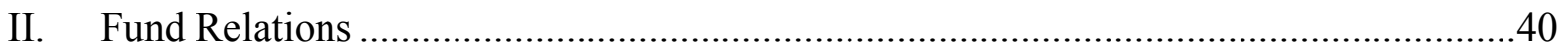

III. Statistical Information................................................................................... 41

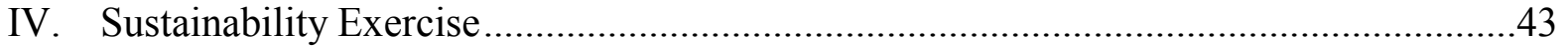

Appendix Tables

A1. Public Sector Debt Sustainability Framework, 1998-2008 ......................................44

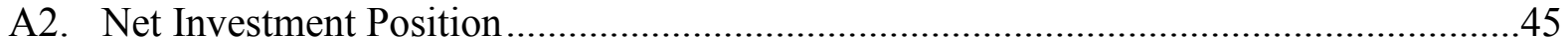

A3. Indicators of External and Financial Vulnerability...................................................46 


\section{EXECUTIVE SUMMARY}

\section{Background}

After faltering in the wake of the Iraq war, economic activity has staged a strong recovery. Real GDP grew by over 2 percent in 2003, with quarterly growth rates rising above trend in the second half. The upswing reflects not only strengthening external conditions but also the continued buoyancy of domestic demand driven by expansionary monetary and fiscal policies, robust increases in house prices and rising household debt. The labor market has been resilient, with unemployment remaining near a 20-year low during the downturn. RPIX inflation remained close to its target, though CPI inflation remains some 0.6 percentage point below the new target of 2 percent. Near term prospects are for an acceleration in growth before settling down to trend rates later this year. Further out, the main risk relates to a hard landing in house prices and private consumption.

\section{Policy Discussions}

Staff and the authorities broadly agreed that against a backdrop of strengthening external demand, macroeconomic policies needed to tighten. The discussions focused on whether or not policy actions were required for the necessary fiscal consolidation and on calibrating the required tightening in monetary policy. The discussions also encompassed structural policies for raising productivity, the outlook and risks for the pension system, financial sector issues and the authorities' assessment of readiness for EMU entry.

- Fiscal consolidation. Over two-thirds of the five percentage point deterioration in the fiscal position between $2000 / 01$ and 2003/4 is estimated by staff as structural. It reflects primarily deliberate increases in spending on public services and unexpected shortfalls in tax receipts attributable to the bursting of the global equity bubble. Staff and the authorities concurred that a gradual strengthening of the fiscal position was needed to respect the government's fiscal rules going forward, improve fiscal fundamentals, and support monetary tightening at this cyclical juncture. The authorities saw the deficit improving sufficiently with the cyclical upswing, a rebound in revenues from the financial sector, improvements in tax collection, and rising effective tax rates from the fiscal drag. In contrast, staff saw the deficit declining only modestly over the medium term without new measures, to $23 / 4$ percent of GDP, some 1 percentage point above the authorities' projections. Thus, additional measures were likely to be needed. In particular, staff saw a case for moderating the government's ambitious spending plans, as a more gradual increase in public spending would reduce the risks of inefficiencies.

- Monetary tightening. There was agreement that a strategy of gradual, early interest rate increases was called for. Uncertainties as to the likely response of consumption to changes in interest rates, related to the unusually high household debt level, called for gradualism. In the staff's view, the case for gradual - and correspondingly "early"increases was strengthened by the risk that late and, thus, larger increases could precipitate a sharp downward adjustment in house prices. 


\section{KeY ISSUES}

1. The performance of the UK economy has remained strong since last year's Article IV consultation. Growth was resilient in 2002, despite the global slowdown, and picked up during 2003, well ahead of continental Europe; investment has remained above historical levels in percent of GDP; unemployment has been stable at record lows; and inflation has stayed close to target (Figures 1-6).

\section{Economic activity benefited from} supportive macroeconomic policies, in the context of clear policy frameworks. Both monetary and fiscal policies have been significantly relaxed over the last three years (see text table and Figures 7-9). This relaxation was received

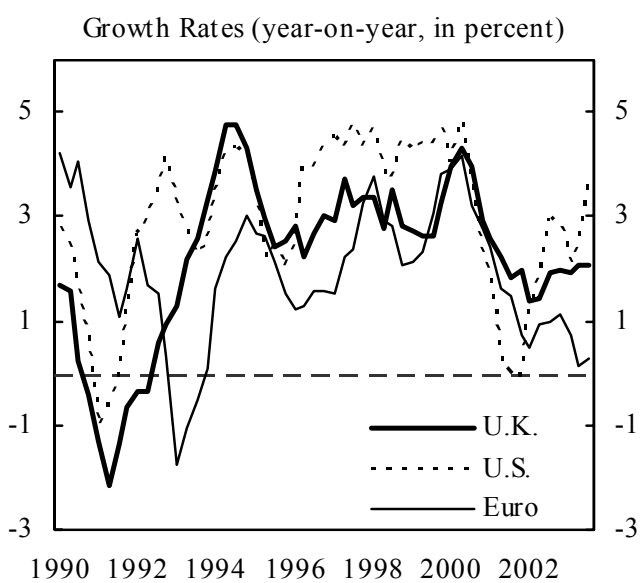
favorably by markets as it was seen as consistent with the stability-oriented monetary and fiscal frameworks introduced during the 1990s: the inflation targeting framework constraining the $\mathrm{BoE}$ to pursue a symmetrical inflation target through a transparent process; and the fiscal rules constraining discretionary fiscal action over the economic cycle. The strong performance of the UK economy in 2002-03 follows years of stable and high growth which benefited from comprehensive reforms of labor, products, and financial markets over the last two decades.

\section{But key challenges remain:}

- Skeptics of the sustainability of the United Kingdom's economic performance have pointed at the boom in house prices and household credit, which began in the late 1990 s and continued in 2002-03. The presence of a possible house price bubble in the economy increases the uncertainty about consumption prospects, traditionally sensitive to house price developments in the United Kingdom, and about consumption's response to a policy tightening. This creates particular challenges to macroeconomic policies at a juncture when the latter need to tighten to rebalance demand towards the external sector

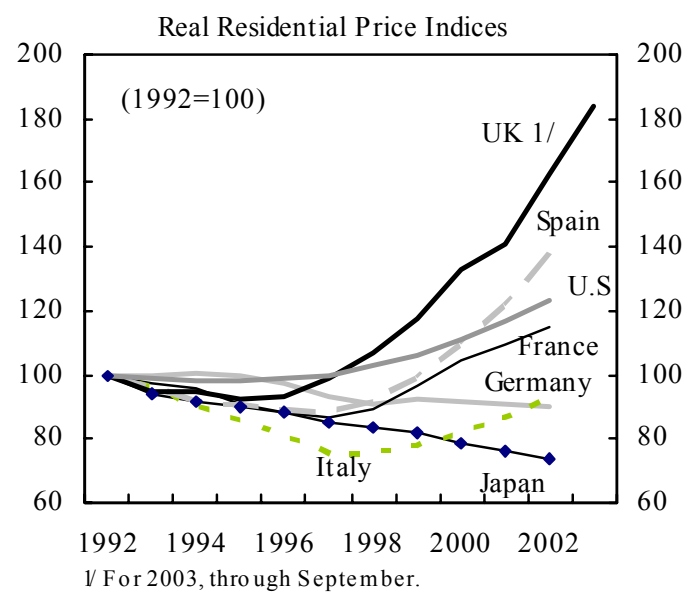


as the global economy recovers. The tightening needs to be carefully calibrated so as to steer consumption and housing markets to a soft landing.

- The fiscal deficit should decline to strengthen fiscal fundamentals, meet the fiscal rules and support the needed monetary tightening going forward. But this decline may conflict with the authorities' ambitious medium-term spending plans, launched in the late 1990s, unless the revenue-to GDP ratio, hard hit by the financial market downturn in recent years, recovers rapidly. Whether this will be the case is highly uncertain.

4. These issues were at the core of the $\mathbf{2 0 0 3}$ discussions. Staff also discussed structural policies for growth, financial sector issues, and the authorities' assessment of the five tests for EMU entry published in June 2003.

\section{THE DISCUSSIONS}

\section{A. Recent Developments and Outlook}

5. After decelerating in the wake of the Iraq war, the economy is staging a strong recovery. Real GDP grew by over 2 percent in 2003, with quarterly growth rates rising above trend in the second half of the year (Tables 1-2). The cyclical upswing reflected not only gradually improving external conditions but also the acceleration of domestic demand. Private consumption - for years amongst the most buoyant in the OECD—after faltering in Q1, recovered during the year. This reflected:

(i) stimulative monetary and fiscal policies, the latter playing a significant role in supporting the labor market and disposable income; (ii) further increases in house prices, which boosted households' confidence and wealth, and provided collateral for increased borrowing; and (iii) continued intense bank competition for retail loans, which facilitated the rise in consumers' unsecured debt. Business investment continued to decline (from an historically high level), reflecting sizable corporate leverage ratios and the need to plug large occupational pension deficits. The external current account deficit is estimated to have increased somewhat but, at just above 2 percent of GDP, remained close to recent averages.

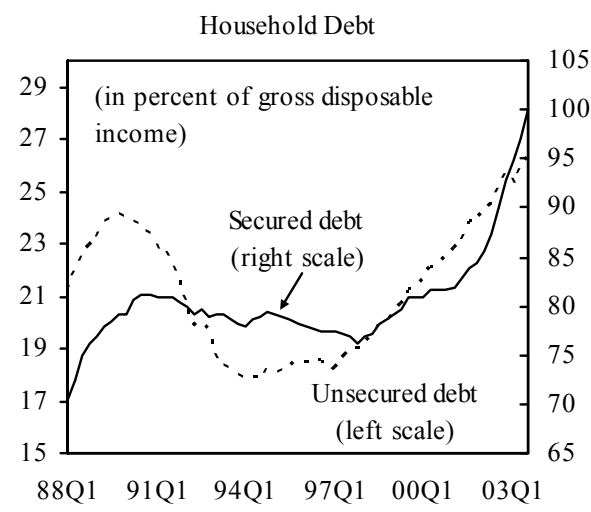

\section{There was broad agreement that the recovery} was likely to continue in $\mathbf{2 0 0 4}$, with staff pointing, in particular, to the strong momentum of consumption. The staff's baseline outlook projects a gradual shift of demand from domestic to external sources as the global recovery gathers pace, and exports benefit 
from the 5 percent nominal effective depreciation of sterling during 2003. But private consumption is projected to remain the key driver of growth through at least mid-2004, supported by the pick up in disposable income and the lagged effect of recent rises in house and equity prices. ${ }^{1}$ Later, consumption would decelerate, as the impact of (expected) higher interest rates feeds through and house price increases moderate. Staff expects business investment to rise only modestly in 2004, reflecting the same factors that hampered it last year. Overall, growth is projected to rise above trend through mid-2004-averaging 3.1 percent in the year-before settling down to potential rates of just above $2 \frac{1}{2}$ percent. With the external outlook improving, and sterling on average over the last year at levels regarded by staff, authorities and business representatives as sufficiently competitive, the external current account deficit was projected to edge down gradually starting in 2004 (Table 4). ${ }^{2}$

\section{The authorities saw a more balanced composition of domestic demand, with} private investment playing a more prominent role. The December Pre-Budget Report (PBR) projected a growth rebound to around 3-31/2 percent in 2004, close to staff's projections. However, business investment was expected to pick up more rapidly than in the staff's baseline. This more sanguine investment outlook relied on confidence effects, as uncertainties regarding geopolitical factors and the global recovery dissipate, and on the increasing appetite for corporate debt shown recently by capital markets. In contrast, the authorities saw consumption slowing to trend already in late 2003. Consumption indicators published after the conclusion of the discussions do not seem to confirm this earlier deceleration.

\section{Differences, particularly between staff} and Treasury, were more marked regarding the current degree of slack in the economy, with implications for growth beyond 2004. Treasury estimated the output gap at $1 \frac{1}{2}$ percent below potential in 2003, against the staff's $3 / 4$ percent (closer to other observers' estimates; see text figure). Staff, in particular, stressed the low level of unemployment, which, at about 5 percent, had hardly been affected by the cyclical downturn

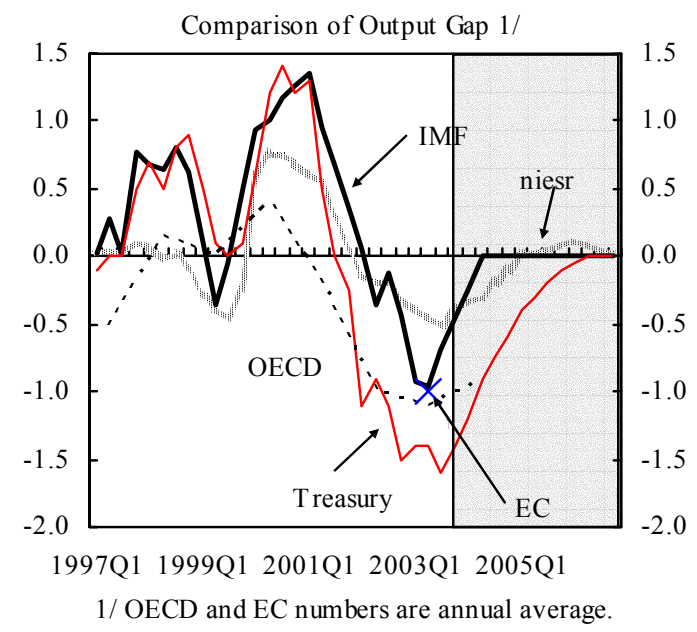

${ }^{1}$ This assessment is backed up by econometric projections based on the model discussed in IMF Country Report 02/46, Ch. II.

${ }^{2}$ This assessment of competitiveness is consistent with the staff analysis in IMF Country Reports $02 / 39$ and $02 / 46$, Ch. III, which finds that the equilibrium rate may have appreciated in the late 1990s reflecting a shift of exports to higher value-added and knowledge-based goods and services, and productivity differentials. Moreover, staff analysis does not suggest any relevant external sustainability problems (Appendix IV). 
(Figure 4). While the rise in public employment and self-employment had helped, the impact on the labor market of the reduced activity had been muffled by lower labor earnings growth, which had declined to about $3 \frac{1}{2}$ percent during the past two years. Thus, as the flip side of improved labor market flexibility, staff saw little room for increased labor utilization without a pickup in earnings and inflation. The Treasury representatives, however, stressed that hours worked had also declined during the downturn and this provided room for noninflationary growth. These differences of views on the current degree of slack in the economy also implied that Treasury saw room for faster noninflationary growth beyond 2004 than the staff. The PBR envisaged the output gap to close by 2006 , with GDP growth of $3-3 \frac{1}{2}$ percent in 2005 , and $2 \frac{1}{2}-3$ percent in 2006 .

9. The near term growth outlook is subject to upside risks on the domestic front and, although fading, downside risks on the external front. On the former, consumption could turn out to be stronger, particularly as house price inflation, while declining from the 2002 peak, has recently remained high (Figure 5). On the latter, with the global recovery gathering momentum, the risks have been diminishing. However, exports could suffer from weaker-than-expected recovery in the euro area, the destination of half of UK exports, or a further depreciation of the dollar.

\section{But, beyond the immediate future, there was agreement that the main risk} related to a hard landing scenario of house prices and consumption. Staff noted recent cross-country evidence suggests housing price booms are followed by busts about 40 percent of the time, with a typical cumulative output loss of about 8 percent (Chapter II, April 2003 WEO). Moreover, with respect to the UK experience, there were obvious similarities between the magnitude of the current surge in house prices and household indebtedness and that of the late-1980s and early-1990s, when a crash did occur (see text figure). ${ }^{3}$ The authorities noted many things had changed since. First, the more stable macroeconomic environment, characterized by lower nominal and real interest rates, might have prompted a rise in the debt level that households can bear and,

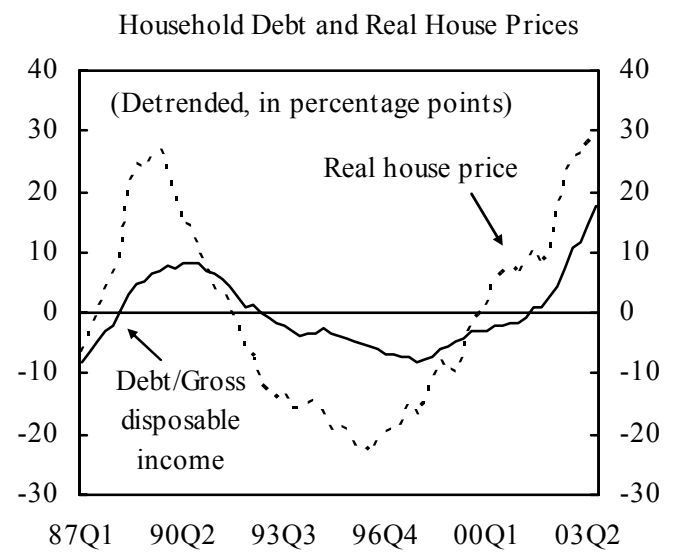
given a relatively inelastic housing supply, in the equilibrium price of houses. And, second, the abrupt interest rates hike that had pricked the early 1990s bubble was unlikely to occur in the present more credible inflation-targeting framework, and in the absence of exchange rate constraints. Rather, the symmetry of the targeting framework would allow the BoE to promptly cut interest rates in the event of a negative shock. But, the authorities concurred, risks remained. The current strength of

${ }^{3}$ Staff estimates house prices to exceed their long run equilibrium by $30-35$ percent, based on the econometric model in IMF Country Report 03/47 (Ch. I). 
household balance sheets was highly dependent on house prices; and information on the distribution of debt as well as liquid assets across households, while limited, indicated it was uneven, thus suggesting high exposure of some segments (Box 1). Moreover, household balance sheet adjustment in a low inflation environment would likely be slower, possibly protracting the adjustment. As to household income gearing ratios, they were low now, but, as recently noted by one MPC member, would rise significantly if rates increased as implied by the current yield curve. More generally, households' response could be particularly sharp if a supply shock affected both inflation, prompting a rise in interest rates, and unemployment, making it difficult for households to service debt and possibly triggering a credit crunch. Altogether, staff and authorities concurred that this called for caution in calibrating monetary policy, avoiding sharp unexpected changes.

\section{Box 1. Household Balance Sheets}

During 2003, household balance sheets have grown further. In Q3 household debt stood at 130 percent of disposable income, a record high, reflecting rises in both secured and unsecured debt.

Households' wealth has also rebounded, to around 650 percent of disposable income (Figure 3). While the size of wealth dwarfs that of debt, the former is highly dependent on the valuation of houses. Moreover, the distribution of debt is uneven.

A recent BoE survey on unsecured debt confirms the findings of the

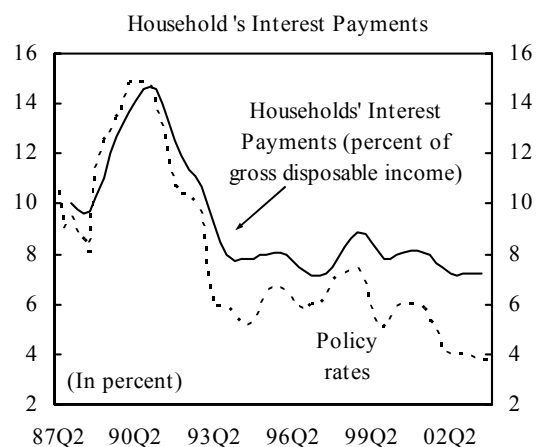
2000 British Household Panel Survey (Box 2, IMF Country Report No. 03/48). During 1995-2003 the average unsecured debt to income ratio of debtors doubled. The increase between 1995-2000 was fairly wide spread across the income distribution. By contrast, the increase since 2000 has been somewhat more concentrated in households with mid to higher income. There is also some evidence that the concentration of debt among riskier borrowers has increased over time. As to the distribution of assets across households, updated survey evidence is limited. However, it appears that only 20 percent of households with high unsecured debt have financial assets compared with 40 percent in the debtor population as a whole. Moreover, based on the 2000 British Household Panel Survey, indebted households do not have larger liquid assets than the average, raising their exposure to adverse shocks.

\section{B. Calibrating Monetary Policy}

11. Inflation has been low and stable since last year's consultation (Figure 3). The retail price index (RPIX) increased by 2.8 percent during 2003. The EU harmonized consumer price index (called CPI in the United Kingdom) rose by 1.4 percent in the same period.

\section{There was broad agreement that the recent shift in the inflation target definition} from RPIX to CPI would unlikely have material implications for monetary policy. Last December, with a view to facilitating convergence with the euro area, the Chancellor changed the MPC's remit to targeting 12-month CPI inflation, rather than RPIX inflation, and because of the different statistical properties of the two indices, lowered the numerical inflation target from $2 \frac{1}{2}$ percent to 2 percent. Staff noted that, in principle, the new inflation 
target was somewhat less ambitious: over the long run, RPIX had tended to rise faster than CPI by some $3 / 4$ percentage points, which was not fully offset by the cut in the numerical target. But this difference was modest. The current difference between the two indexes was larger (1 $1 / 4$ percentage point), but was due to the house price boom, and was thus expected to be temporary. As to the transparency of the inflation targeting process, the new target might complicate communication of forthcoming interest rate hikes, as CPI inflation is currently well below target. This was seen perhaps as the most significant issue by MPC members. But it was viewed as manageable, as the forward-looking nature of inflation targeting was now accepted not only by the cognoscenti but also by the public at large (Box 2).

\section{Regarding actual monetary policy implementation, staff supported the recent} rate increase and concurred that further increases were likely to be needed if the cyclical upswing continued. After over two years of cuts, the MPC raised rates by 25 basis points last November and again by 25 basis points in February (to 4 percent). The MPC minutes indicate that: (i) the move reflected clear signs of brighter external prospects, the observed recovery in activity, and strong credit growth (Figure 6); and (ii) interest rates would be raised further if the economy continued evolving as projected. Staff supported this approach which was in line with market expectations. First, the output gap was small, as recently stated also by the BoE Governor, and, in the staff projections, would disappear by mid-2004. Second, recently muted imported inflation was now expected to rise with

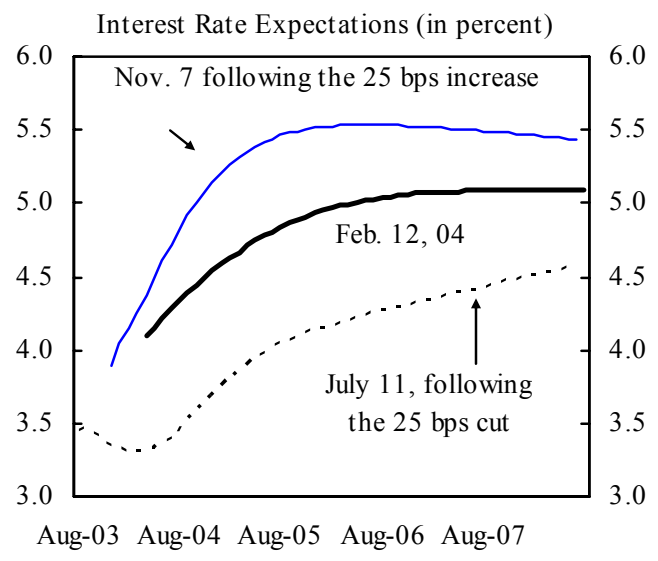
the global recovery and the pass-through of sterling's 2003 depreciation. Altogether, on current demand projections, CPI inflation was expected to edge up from the current 1.4 percent level towards the 2 percent target, and to exceed it in the absence of rate changes. In the staff's view, the case for tightening was reinforced by the ebullience of the housing and household credit markets. On the latter point, MPC members agreed that asset price considerations should be factored into an inflation targeting framework, but views among them differed as to the extent to which this was, in practice, possible (Box 3).

14. There was also agreement that a strategy of gradual, early interest rate increases was appropriate. MPC members emphasized that the uncertainties as to the likely response of consumption to changes in interest rates, related to the unusually high household debt level, called for gradualism. Staff also noted that the case for gradual - and correspondingly "early" - increases was strengthened by the risk that late and, thus, larger increases would precipitate a sharp downward adjustment in house prices. Staff also stressed that gradualism in interest rate increases would be facilitated by supportive fiscal policies. 


\section{Box 2. Does the Shift from RPIX to CPI Matter?}

The $3 / 4$ percentage point long term difference between RPIX and CPI inflation is due in part ( $1 / 2$ percent) to the use by the latter of geometric averages, rather than arithmetic averages. This "formula effect" is offset by the change in the numerical target. The residual long term-difference ( $1 / 4$ percentage point) mostly reflects the fact that RPIX includes a distributed lag of house price increases (as proxy for house maintenance costs), which have tended to rise faster than CPI. This difference may disappear as the EU's HICP (and hence the UK's CPI) is broadened to include imputed rents from owner-occupied housing.

The current difference is larger: $1 \frac{1 / 4}{4}$ percentage point and $3 / 4$ after adjusting for the formula effect. Does it matter? Probably not.

The current difference reflects the unusually large house price inflation. But, as noted by MPC members, inflation targeting was forward looking, and house price inflation was not expected to continue at these levels. More generally, house prices were hard to predict and so their direct effect on MPC decisions had, in practice, been limited (see Box 3 for a discussion of indirect effects).

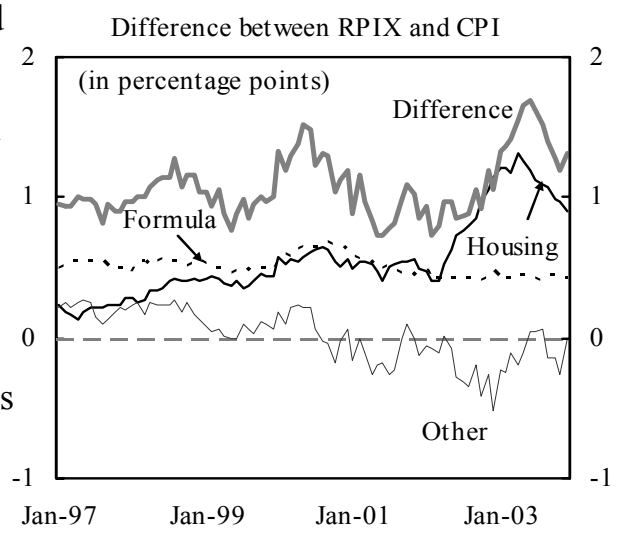

Moreover, indexation practices (of benefits, tax schedules, and interest payments) have never used RPIX anyway (but the more traditional RPI, which includes the effects of mortgage interest payments). Social partner representatives believed that agents could see through these definitional differences and that wage negotiations would not be affected either.

\footnotetext{
Box 3. Asset Prices and Inflation Targeting

Asset prices may affect policy decisions in an inflation targeting framework essentially in two ways: (i) through their impact on demand via wealth and liquidity effects; and (ii) because a bubble might eventually burst possibly causing major recessionary effects on demand and inflation sometime down the road. Views across MPC members varied as to the extent to which this second channel could in practice be taken into account. Difficulties included: identifying the existence of a bubble, anticipating the effect that interest rate increases would have on it, and having to choose between facing an immediate, likely, but possibly small, inflation undershooting (if interest rates were raised to contain the bubble) and a possibly larger, but uncertain, undershooting (if rates were not raised, the bubble kept growing, and eventually burst). ${ }^{1}$

Staff acknowledged these difficulties ${ }^{2}$ but noted that the MPC minutes had explicitly (and appropriately) referred to this second channel to justify its interest rate decisions (including in explaining the November 2003 rise).

In this respect, staff also suggested that, in order to facilitate communication of the rationale of certain interest rates decisions, the Inflation Report of the BoE could usefully discuss inflation forecasts beyond its standard 2-year horizon, as the potential effect of asset price bubbles may extend over time. The authorities acknowledged that reducing the emphasis on the 2-year horizon was in line with the inflation targeting remit (requiring keeping inflation at 2 percent at all times). But, they stressed, focusing on a single time horizon had the advantage of simplicity.

${ }^{1}$ See, for example, "Asset Prices, Monetary Policy and Financial Stability: A Central Banker's View" (presentation at the 2003 American Economic Association conference), by Charles Bean, MPC member.

${ }^{2}$ See also IMF Country Report 03/48.
} 


\section{Does the Fiscal Correction Require New Measures?}

15. The budget position has swung from a 11/2 percent of GDP surplus in 2000/01 to a projected 3 $1 \frac{1}{2}$ percent of GDP deficit in $2003 / 04$. Over two thirds of this five-percentagepoint deterioration is structural (that is, unrelated to the business cycle) and reflects primarily deliberate increases in spending on public services, especially in health, education, and transport; and unexpected shortfalls in tax receipts. The latter are due to the bursting of the global equity bubble, ${ }^{4}$ and, this fiscal year, overoptimism in projecting wage growth and related taxes (Figure 8 and Table 5). Higher-thanexpected spending on security and on tax credits and benefit programs has also contributed to increase borrowing, but only recently. This large fiscal expansion has been consistent with the UK fiscal framework, centered on the golden rule and the sustainable investment rule, because of the margins accumulated in the late 1990s. But these margins have been rapidly shrinking (see text figure). ${ }^{5}$

16. Reflecting the unexpected shocks, fiscal outturns have fallen short of targets for three consecutive years, in both nominal and structural terms. This year the PBR revised the projected deficit up by about one percentage point of GDP for entirely noncyclical reasons only six months after the publication of the budget.

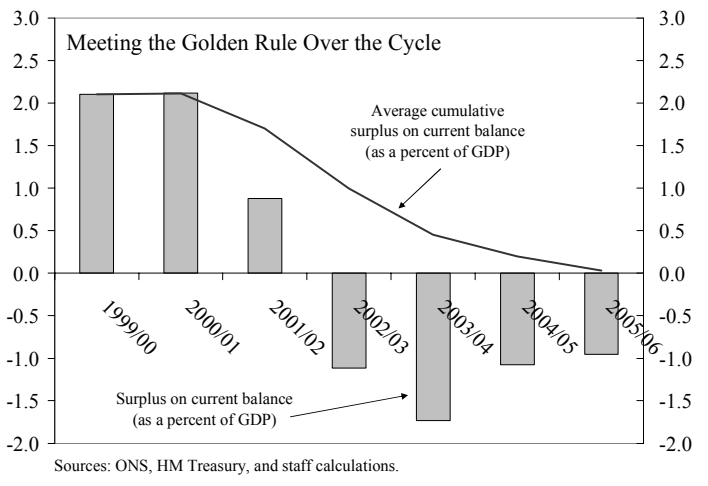

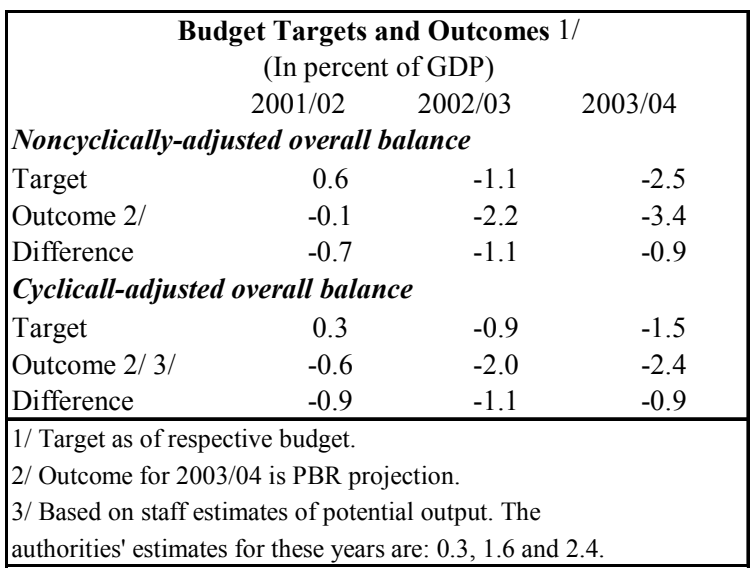

\footnotetext{
${ }^{4}$ This affected both corporate income taxes (from the taxation of financial company profits) and personal income taxes (from the taxation of incomes of financial sector employees).

${ }^{5}$ The golden rule requires the current balance to be non-negative in the average of the business cycle, which the authorities estimate to have begun in 1999/00 and to end in 2005/06. The sustainable investment rule requires the net public debt-to-GDP ratio to be at a stable and prudent level, which Treasury has regarded to be below 40 percent. While the second rule is also defined over the cycle, Treasury is committed to keep the debt ratio below 40 percent at all times.
} 


\section{Against this background, staff and authorities concurred that a gradual and} predictable strengthening of the fiscal position was needed to: (i) respect the fiscal rules going forward; (ii) improve fiscal fundamentals - the current structural primary deficit would imply a rising debt stock over time (Box 4); and (iii) support monetary tightening at this cyclical juncture, reducing the risk of large and unexpected interest rate hikes that may prevent a soft landing of consumption and the housing market. Consistently, the PBR envisaged a gradual decline of the deficit, to about $13 / 4$ percent of GDP in 2008/09, starting with a structural adjustment of almost $1 / 2$ percent of GDP in 2004/05. ${ }^{6}$ Staff regarded the latter as an appropriate target to provide a clear signal of change in course, but called for a somewhat more ambitious medium-term goal-a deficit of $1-$ $1 \frac{1}{2}$ percent of GDP. Outcomes at the upper end of this range would allow net public debt to stabilize

\begin{tabular}{|c|c|c|c|c|}
\hline \multicolumn{5}{|c|}{$\begin{array}{c}\text { Fiscal Balances and Public Debt 1/2/ } \\
\text { (In percent of GDP) }\end{array}$} \\
\hline \multirow{3}{*}{$\begin{array}{l}\text { Overall balance } \\
2003 \text { PBR }\end{array}$} & \multirow{3}{*}{$\begin{array}{l}2002 / 03 \\
\text { Outturn } \\
-2.1\end{array}$} & \multirow{2}{*}{\multicolumn{2}{|c|}{$\begin{array}{r}2003 / 042004 / 05 \quad . . \\
\text { Projections }\end{array}$}} & \multirow[t]{2}{*}{$2008 / 09$} \\
\hline & & & & \\
\hline & & -3.4 & -2.6 & -1.7 \\
\hline Staff & -2.2 & -3.4 & -3.0 & -2.7 \\
\hline \multicolumn{5}{|c|}{ Cyclically-adjusted overall balance } \\
\hline 2003 PBR & -1.6 & -2.4 & -2.0 & -1.7 \\
\hline Staff & -2.0 & -2.9 & -2.9 & -2.7 \\
\hline \multicolumn{5}{|l|}{ Net public debt } \\
\hline 2003 PBR & 30.9 & 32.8 & 33.8 & 35.5 \\
\hline Staff & 31.6 & 32.7 & 33.9 & 38.6 \\
\hline \multicolumn{5}{|c|}{$\begin{array}{l}\text { Sources: Budget 2003, and staff projections. } \\
\text { 1/ Official projections based on official GDP, and } \\
\text { staff projections based on staff's GDP. } \\
\text { 2/ In fiscal years, which run from April to March. }\end{array}$} \\
\hline
\end{tabular}
at about 35 percent of GDP, leaving room for accommodating shocks within the sustainable investment rule. The lower end of the range would reduce crowding out of private investment and provide an additional buffer against potential liabilities, particularly those from population aging. The latter were well below those of euro area countries, which justify a less tight structural fiscal target, but, while difficult to quantify, risks were not trivial (see Section E).

\section{Box 4. Fiscal Sustainability}

Staff's analysis - using the standard cross-country template and taking staff projections as the baseline (Appendix IV) - shows that, on unchanged policies, public debt would keep rising, reflecting the current primary structural deficit and the cautious assumption that, on average, the interest rate on debt exceeds the GDP growth rate. Even in this case, debt financing is unlikely to be problematic over the next few years, as public debt would rise slowly and from a low level (around 32 percent of GDP in 2003 for net debt; 38 percent of GDP for gross debt).

But a correction would eventually be needed, because fiscal trends would be increasingly unfavorable as debt and interest payments rise. The more so if one allows for the fact that the debt increase may affect the yield on government securities. Indeed, there is some evidence, including econometric results controlling for differences in cyclical positions, that UK yield differentials vis-à-vis the euro-area have recently been unfavorably affected by rising relative supply of UK bonds (see figure).

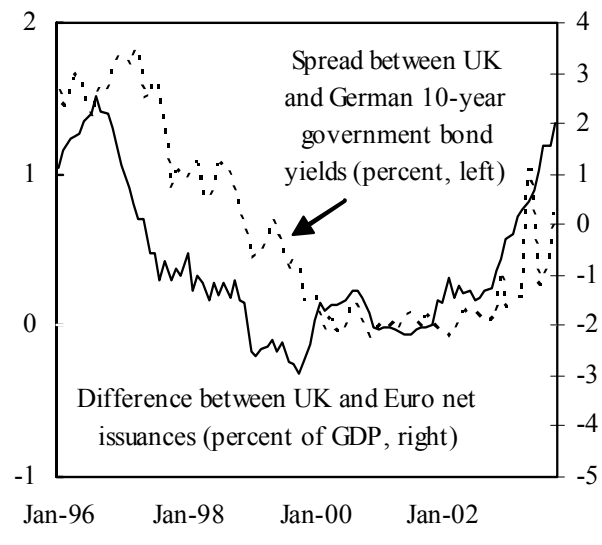

${ }^{6}$ These are not yet firm targets. The latter will be set in the 2004/05 budget. 


\section{But views differed as to whether new fiscal measures would be needed to}

\section{improve the fiscal accounts.}

- In the $P B R$ projections, the deficit improves without any new measures, reflecting: the cyclical upswing; a rebound of tax revenue related to the financial sector to levels close to the late $1990 \mathrm{~s}$ boom; improvements in tax collection; and rising effective tax rates due to the fiscal drag (since tax brackets are uprated with prices rather than incomes). Altogether, the tax revenue to GDP ratio was projected to rise above recent historical peaks over the next few years (see text figure).

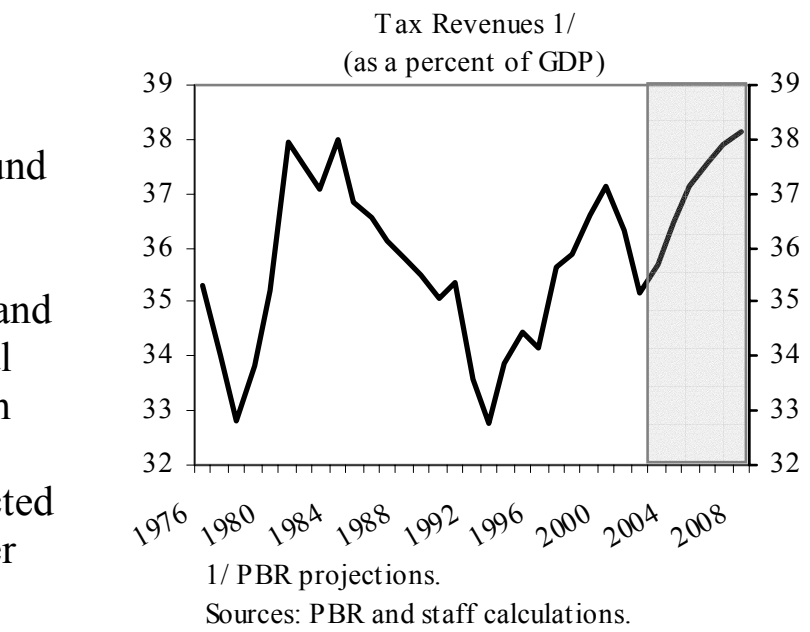

Tax Revenues 1/

- In contrast, staff projections indicated that without new measures the deficit would decline more modestly than projected by the authorities, both in 2004/05 and over the medium term. The gap would be about $1 / 2$ percent of GDP in $2004 / 05$, and rise gradually to 1 percent of GDP by 2008/09. In particular, staff projected lower revenue growth reflecting the lower estimate of the output gap (see paragraph 10 above), which implied a weaker cyclical rebound of revenue; and a more subdued recovery of tax receipts from financial activities, as staff saw those receipts as abnormally boosted by the financial boom of the late 1990s. ${ }^{7}$ In this baseline scenario, the golden rule would barely be met in this business cycle and the current balance would be in deficit at the start of the new business cycle. Additional fiscal risks would arise if a sharp unwinding of the house price bubble led to a period of prolonged economic weakness.

19. Staff acknowledged the substantial uncertainties associated with these projections but emphasized the need to act promptly if, as in the recent past, fiscal developments turned out to be disappointing. New fiscal slippages would increase the burden on monetary policy at a delicate juncture and the risk of triggering a hard landing scenario. Moreover, breaching the golden rule could involve a severe credibility loss for the authorities. The authorities remained confident their projections would materialize, noting that: (i) there were already signs this year that financial sector incomes were recovering rapidly; and (ii) while revenues had been overprojected during the last three years, they had been underprojected in the late 1990s, suggesting no systematic bias. In any case, they remained committed to introducing new measures if needed to meet their fiscal rules with a sufficient margin.

\footnotetext{
${ }^{7}$ For the effect of asset price booms on tax buoyancy see "Asset Prices and Fiscal Balances," ECB Working Paper No. 141, by F. Eschenbach and L. Schuknecht (May 2002).
} 
20. In the staff's view, the case for fiscal adjustment, and specifically for revising the government's ambitious spending plans, was strengthened by the risk that the latter could involve significant inefficiencies. While the expenditure policy framework had been improved - by strengthening monitoring, accountability, and incentives ${ }^{8}$ - the evidence that increased spending was bearing commensurate fruits was still scarce (as also stressed by the most recent OECD report on the United Kingdom):

\begin{tabular}{|c|c|c|c|c|}
\hline \multicolumn{5}{|c|}{$\begin{array}{c}\text { Expenditure Increases Under } \\
\text { Department Expenditure Limits (DELs) } \\
\text { (Real growth rates, in percent) }\end{array}$} \\
\hline & 2003/04 & $2004 / 05$ & $2005 / 06$ & $\begin{array}{c}\text { Cumulative } \\
\text { increases }\end{array}$ \\
\hline Education & $6.7 \%$ & $3.5 \%$ & $6.5 \%$ & $17.6 \%$ \\
\hline Health & $10.5 \%$ & $6.9 \%$ & $7.2 \%$ & $26.6 \%$ \\
\hline Transport & $15.2 \%$ & $0.0 \%$ & $1.9 \%$ & $17.4 \%$ \\
\hline
\end{tabular}

- National accounts data showed that increased public spending had been accompanied by a sharp rise in the public consumption deflator. The authorities noted that this rise was mainly related to planned increases in public sector wages, high set-up costs related to IT infrastructure, and perhaps, most importantly, problems with the proper measurement of the quality and quantity of public sector services. Staff acknowledged that mismeasurement problems could be the main cause for the rising deflator and welcomed the review launched by the statistical office to improve the

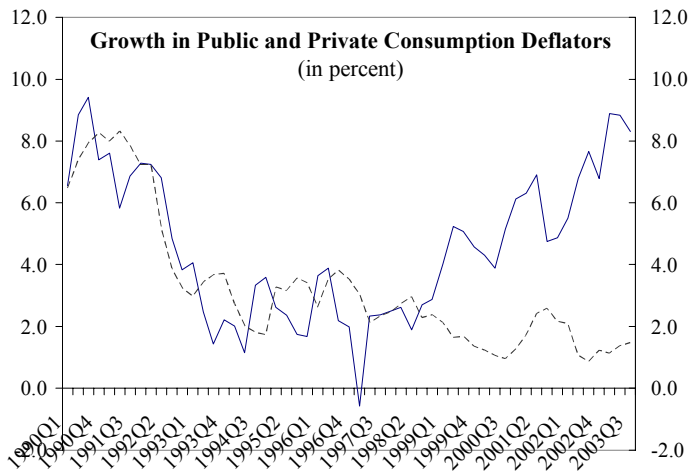
measurement of public sector output. But, the possibility of supply bottlenecks could not be ruled out - especially in areas such as transportation, where measurement problems were less significant.

- More importantly, while direct indicators of public services delivery did show some improvement since 1997, in most cases this improvement had taken place before the recent spending surge. Survey evidence also suggested a limited improvement in the population's satisfaction with public services. The authorities explained these developments mainly with gestation lags between spending and delivery-but noted that they would continue to monitor developments closely.

\section{Staff also suggested that fiscal adjustment and efficiency could benefit from} broadening the application of user fees in public services. They welcomed the initiation

${ }^{8}$ The United Kingdom has also pioneered the use of Public-Private Partnerships (PPP) and Private Finance Initiatives (PFI). Projects under PPP/PFI aim to involve the private sector in those public delivery areas where private initiative has a comparative advantage, and are subject to special accountability and transparency requirements to safeguard the comprehensiveness of the budgetary process and avoid contingent liabilities. Unlike PPPs, the PFIs involve risk sharing between the private and public sectors. 
during 2003 of congestion charges in some cities, and the authorities' intention to introduce variable tuition fees in higher education. However, more was needed to contain rising public sector costs, including through the introduction of user fees in the health sector.

\section{Assessment of the Five Tests for EMU Entry ${ }^{9}$}

22. Since the last consultation, in June 2003 the Treasury published its assessment of the five economic tests for EMU entry and concluded that the case for entry was not yet established. The UK government decided in 1997 that it would support EMU entry once the economic case for joining appeared to be "clear and unambiguous" based on five economic tests to be assessed by Treasury (see text table). The assessment published in June 2003 concluded that only the "financial services test" on whether entry would benefit the financial services industry, was considered as met.

Two tests (the "investment test" and the "growth, stability and employment test," on whether entry would be good for these macroeconomic variables), would be met only once "sustainable convergence" between the United Kingdom and the euro area was achieved. However, the two tests focusing on the existence of sustainable convergence (the "convergence test" - on whether business cycles and economic structures are compatible with those of the euro area-and the "flexibility test"- on whether the UK economy is sufficiently flexible to respond to idiosyncratic shocks (in the absence of monetary independence)

\begin{tabular}{|l|l|}
\hline \multicolumn{2}{|c|}{ Summary Assessment of Five Tests } \\
Test & No03 Assessment \\
\hline $\begin{array}{l}\text { 1. Cyclical and structural } \\
\text { convergence }\end{array}$ & Not met \\
\hline $\begin{array}{l}\text { 2. Sufficient flexibility to } \\
\text { adapt to shocks } \\
\text { Gains in: }\end{array}$ & Not met \\
\hline 3. Investment & $\begin{array}{l}\text { Would be met, given } \\
\text { convergence and flexibility }\end{array}$ \\
\hline 4. Financial services & Met \\
\hline $\begin{array}{l}\text { 5. Growth, stability, and } \\
\text { employment }\end{array}$ & $\begin{array}{l}\text { Would be met, given } \\
\text { convergence and flexibility }\end{array}$ \\
\hline
\end{tabular}
were not regarded as met. In particular, Treasury highlighted that, reflecting differences in the structure of the housing and household debt markets, the UK economy was subject to idiosyncratic shocks and featured an idiosyncratic monetary transmission mechanism. Treasury, however, found that there had been significant progress in meeting the conditions for entry since the 1997 assessment. On this basis, the government has decided to take steps to facilitate euro-convergence (Box 5), and to review progress at the time of the budget in 2004.

\footnotetext{
${ }^{9}$ See Selected Issues Paper, "The June 2003 EMU Assessment."
} 


\section{Box 5. Steps to Facilitate EMU Entry}

In addition to adopting the EU harmonized inflation index as monetary policy target, the government launched two reviews to identify reforms to dampen house price and consumption volatility. While final conclusions are not due until Spring 2004, the interim reports of the reviews were recently published:

The Barker Review is focusing on why UK housing supply is price inelastic. The interim report identifies several contributing factors - such as a stifling planning system and infrastructure barriers, adverse behavior of the housebuilding industry, and limited incentives for local authorities to build new houses - and discusses policy options in the areas of taxation, regulation, and subsidies.

The Miles Review is investigating why the share of long-term fixed-rate mortgages is relatively low in the United Kingdom. Its interim report concludes that the existing bias towards variable-rate mortgages is not due to institutional impediments or market failure but to poor understanding of risk and lack of information on the part of consumers. It thus calls for improved awareness initiatives.

The assessment also reiterates the government's commitment to promote flexibility in labor, product, and financial markets, which should facilitate meeting the flexibility test, and reviews the ongoing initiatives in this area. Finally, the government opened a discussion on possible reforms of the fiscal framework that, after joining EMU, could reinforce the stabilization role of fiscal policy.

\section{Staff welcomed the authorities' extensive analyses of the economic pros and cons} of EMU entry. These analyses were of very high quality and had helped clarify the issues and the authorities' approach to them. The assessment paper and its eighteen background studies covered in great depth issues such as the benefits from entry arising from increased trade, the implications of the permanent loss of monetary flexibility, and the short-term costs of entering when cyclical conditions were different from those of the euro area. It also stressed that, given the irreversibility of entry, the authorities needed to feel confident that the case for entry had been established with a sufficient degree of certainty, and that otherwise it would be appropriate to allow more time to permit a more informed assessment. In that vein, the reform steps that the government was considering to reduce housing market volatility were not only consistent with the goal of EMU entry but appropriate in their own merits.

\section{Looking to the next assessment of the five tests, staff suggested that further} attention could be given to some difficult, yet critical, issues. In particular, the recent assessment had taken the view that the large potential long-term gains from entry (arising essentially from increased trade) would materialize only if the United Kingdom entered once a sufficient degree of convergence had been achieved. However, further empirical work would be helpful in quantifying the effect of insufficient convergence on those long-term gains. On another plane, while agreeing that further structural reforms to enhance flexibility were in any case desirable, more could be done to explain the benchmarks by which flexibility should be regarded to be sufficient (the recent assessment regarded flexibility insufficient in spite of the progress made since 1997 from an already enviable position). 
Finally, more attention could also be paid to evaluating some costs of postponing entry. A more complete treatment of these issues would strengthen any conclusion reached by the next assessment.

\section{E. Structural and Financial Sector Issues}

25. The authorities' approach to ensuring adequate pensions remains centered on a high and increasing role of private pension schemes as the population ages. Current and future public pension obligations are modest compared with most other European economies. This reflects less unfavorable demographics and higher reliance on private pension schemes, as public pensions are expected to provide only basic pension benefits, and are partly means tested. ${ }^{10}$ Official projections indicate that public pension spending will remain stable at about $5-5 \frac{1}{2}$ percent of GDP over time, as overall age-related spending needs increase by $3 \frac{1}{2}$ percentage points of GDP by 2050 . In the same period, the share of pensioners' income from private sources is projected to rise from the current 40 percent to 60 percent.

26. However, the financial (and political) viability of this system depends crucially on whether people are saving enough for retirement; this is far from clear. ${ }^{11}$ Over the past few years, the authorities have enacted several measures with the goal of fostering private savings through new saving vehicles-e.g., new easy-to-transfer standardized pension and saving products aimed at low- and middle-income sectors. But some recent developments have raised concerns. These include indications that pension-related saving, particularly among low-income sectors is too low; financial difficulties experienced by the life insurance industry; and significant deficits in some company-sponsored occupational pension schemes. Staff noted that these developments, if not corrected, may involve sizable future liabilities for the fiscal accounts (as pressure for widening the benefits provided by the state would rise, and as more people would qualify for means tested benefits). A proactive approach was thus required to assess the performance of the current strategy and change course if needed. In this regard, they welcomed the establishment of an independent Pension Commission, entrusted with assessing the need for further reforms, including the potential advantages of strengthening compulsory saving elements in the system.

${ }^{10}$ The features and long-term prospects of the pension system are discussed in the Special Issues Paper, "Aging and the U.K. Pension System."

${ }^{11}$ For example, evidence from the 2002 Green Paper suggests that at present about 3 million people are seriously under providing for their retirement, while a large group of 5 to 10 million may need to save more or work longer in order to achieve a replacement rate of 66 percent. 
27. Another key structural challenge is raising UK productivity - which lags about 20 percent behind other comparable economies. ${ }^{12}$ Although the evidence is still unfolding, the gap with respect to the United States appears to be rooted in lower research and development spending, weaker managerial practices, and shortcomings in the competitive environment. Lower workforce skills and capital stock could explain the gap with respect to the leading continental European economies. The authorities have responded with a multi-pronged approach with initiatives addressing all key drivers of productivity: competition, enterprise, science and innovation, skills, and investment.

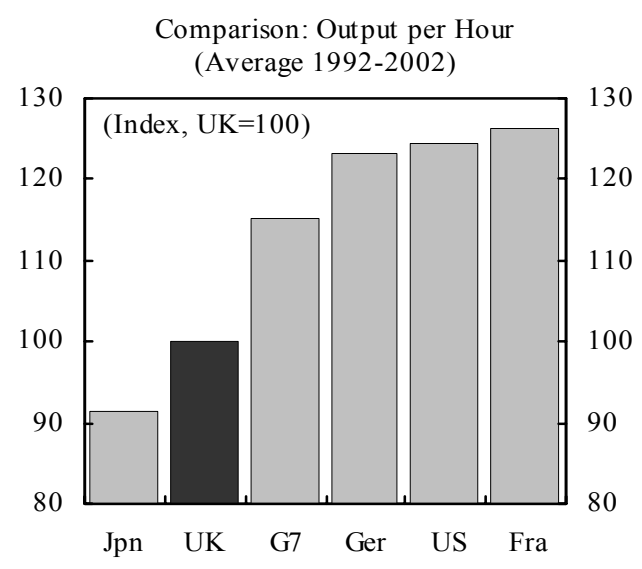

28. While staff reiterated its support of recent initiatives in these areas, it saw a need for systematic monitoring and evaluation of ongoing programs. This would allow for the retirement of unsuccessful initiatives, the extension of successful ones, and a targeted prioritization over time. The extension of the $R \& D$ tax credit to all corporations and the expansion of training programs reflect good reception by the business community and positive appraisals by independent evaluations and researchers. But initiatives in this area have proliferated in recent budgets and the strategy could benefit from a pruning of programs. Discussions also focused on the institutional setting for promoting competition which had been substantially reinforced in recent years by expanding the powers and independence of the Competition Commission and the Office of Fair Trading. The implementation of the Enterprise Act in June 2003 culminated this phase of reform of the system, with the emphasis now shifting to ensuring its effective operation.

29. Programs for further enhancing the already high employment rate may also need closer monitoring. Both authorities and independent analysts indicated that some of the active labor market policies concentrated around the New Deal programs, particularly those targeted at the unemployed aged 18-24, had been successful. Staff welcomed the announcement in the PBR of plans to enhance this approach for those aged over 24. But the effectiveness of other New Deal programs aimed at incorporating specific groups into the labor market was still to be demonstrated. Some of these programs may need stronger job search incentives.

30. Overall, the UK financial system has proved resilient to the global slowdown and is set to benefit from the ongoing recovery in growth and stock markets.

12 This issue was discussed more extensively during the 2002 Article IV consultation; see IMF Country Report 03/47 (Ch. II). 
- $\quad$ Banks' profitability and capitalization levels remain high. Going forward, the mix of risks will evolve with changes in the macroeconomic environment. As the 2002 FSAP indicated, banks' portfolios may experience a deterioration as a result of higher interest rates and significant declines in property prices, given the high levels of household and corporate indebtedness. However, banks' high profitability and capitalization levels should allow them to absorb likely macroeconomic shocks without systemic distress. ${ }^{13}$ Over the medium term, the ongoing trend compression of margins owing to increased competition in retail banking may dampen profitability as credit growth decelerates.

- $\quad$ The insurance industry has been under considerable stress in recent years. Conditions have now stabilized and capitalization has improved, including through resort to capital markets. The sector has also benefited from the rebound in equity markets in 2003. But, as documented in the FSAP, weaknesses remain - although the authorities indicated that they affected mostly firms with little systemic impact. The ongoing reform of insurance regulation by the FSA aims to apply a risk-based framework (now primarily used for banking supervision) to the insurance industry. When implemented, it will strengthen the sector and minimize the risks of systemic stress.

- $\quad$ The authorities have also further strengthened the procedures and institutional arrangements of the payment and settlement systems with a view to enhancing their efficiency and minimizing settlement and counterparty risk.

\section{F. Other Issues}

31. The United Kingdom has consistently supported trade liberalization within the context of EU membership. Staff welcomed the authorities' intention to press for resuming negotiations under the Doha round and for further flexibility in the EU on the "Singapore issues" (investment, competition, government procurement, and trade facilitation) in the context of the round. The authorities also reiterated their support for CAP reform. They thought there was room for going beyond the Commission's proposal in some areas (for example, they would prefer a higher level of compulsory decoupling for cotton and olive oil, and a more liberalized regime for sugar with prices closer to world levels). They also indicated that the UK, after the 10-year transition phase, was ready for the elimination of the quota regime for textiles and clothing (the "multi-fiber arrangement"), except for some small businesses. Regarding less developed countries' access, the United Kingdom was advocating

${ }^{13}$ A fall in real estate property prices was among the scenarios explored by the FSAP as part of its stress testing. The analysis indicated that this scenario had a relatively large loss potential - particularly if the fall in real estate prices were to coincide with high unemployment and interest rates. Nevertheless, the FSAP concluded that the potential losses were unlikely to exceed annual profits or represent a large portion of banks' capital. More recently, both the Financial Stability Review of the BoE and the Financial Risk Outlook of the FSA also highlighted the risks to bank profitability that could arise from this source. 
that the European Commission review its Rules of Origin requirements to ensure that the intended countries would be able to take full advantage of current preferential agreements, such as the Everything-But-Arms initiative.

32. The government has continued strengthening the legal framework to combat money laundering and the financing of terrorism (AML/FT). The anti-money laundering provisions of the new Proceeds of Crime Act were implemented in February 2003 expanding AML coverage and reporting obligations-which the authorities are extending further to accountants, lawyers, and other relevant agents, as recommended by the FATF, through new AML regulations coming into force on March 1, 2004. This completes the implementation of the Second EU Money Laundering Directive. The OECD Bribery Working Group considers that UK legislation addresses the requirements of the OECD Anti-Bribery Convention.

33. The United Kingdom is committed to increase ODA from 0.32 percent of national income in 2002/03 to 0.4 percent in 2005/06, with the final goal of achieving the United Nations target of 0.7 percent.

\section{StAfF APPRAISAL}

34. The UK economy has weathered the global slowdown well, supported by an appropriately countercyclical monetary policy and an expansionary fiscal stance. Growth has been resilient relative to other industrial countries, inflation has remained close to target, and unemployment has been low and stable. Crucial to this performance, macroeconomic policies have been expansionary without undermining confidence-owing to well established and transparent monetary and fiscal policy frameworks with a distinct medium-term orientation. The driving force has been domestic consumption, supported by continued increases in house prices and household debt. This strong performance also reflected structural factors, including the flexibility of labor, product, and financial markets which have been deeply reformed over the last twenty years.

35. With the external environment improving, and continued strong momentum of domestic demand, the growth outlook remains favorable. The pace of consumption continues to be strong, but is expected to moderate during 2004, as the impact of higher interest rates feeds through, thus making room for the projected strengthening of external demand. Overall, growth is projected to remain above trend at 3 percent in 2004 before settling down to potential rates of around $2 \frac{1}{2}$ percent.

36. The main risk to this outlook stems from an abrupt correction in housing and credit markets. In the immediate future, given its strong momentum, the risks for consumption and output growth are still on the upside. But, further out, the possibility of a reversal remains. House price and household debt developments in recent years are reminiscent of those of the late 1980s, whose reversal contributed to the early $1990 \mathrm{~s}$ recession. Admittedly, the overall structural conditions of the UK economy, including its policy frameworks - albeit untested in a period of major stress - are considerably stronger than in the early 1990s. But, in the presence of considerable uncertainty on the distribution of 
asset and liabilities of households, and on the latter's exposure to a sharp rise in interest rates and unemployment, the possibility of a disruptive correction cannot be ruled out. To minimize these risks, cautious macroeconomic policies are needed.

37. In the fiscal area, the deficit needs to be kept on a predictable adjustment path. The deficit has widened rapidly, including in structural terms, in the last three years, exceeding every year the initial budget projection. Lowering the deficit from the $3 \frac{1}{2}$ percent of GDP projected for 2003/04 is needed to meet the fiscal rules, strengthen fiscal fundamentals, and support monetary policy during the cyclical upswing. An adjustment of $1 / 2$ percent of GDP in the structural deficit already in 2004/05, in line with the PBR projections, would provide a visible signal of change in course. The adjustment in the structural position should continue in later years, with the goal of lowering the structural deficit to $1-1 \frac{1}{2}$ percent of GDP over the medium term. The upper bound of this range would stabilize public debt at around 35 percent of GDP, leaving a reasonable margin under the 40 percent of GDP debt ceiling; the lower bound would allow an additional margin to face future contingent liabilities, including those from population aging, and involve a lower crowding out of private investment. The automatic stabilizers should be allowed to operate fully around this adjustment path.

38. But the authorities' fiscal projections are subject to considerable risks and additional measures will likely be needed. The PBR projects the deficit to fall along a path only slightly less ambitious than indicated above in the absence of measures, reflecting a sharp recovery in revenues. But under staff's more conservative assumptions, the deficit on current policies would decline to only $23 / 4$ percent of GDP over the medium term1 percentage point above the PBR projections — only a modest adjustment with respect to the current level, with a gap already emerging in 2004/05. Thus, the authorities should follow developments closely and take corrective actions promptly, if needed. New fiscal slippages should be avoided as the risk of breaching the golden rule would not be trivial and as slippages would involve excessive strain on monetary policy in a delicate cyclical phase.

39. Moderating the ongoing steep escalation in spending would limit the risk of inefficiencies and help fiscal consolidation. The authorities have continued strengthening the expenditure management framework. However, there is not yet enough evidence that increased spending is producing value for money. A slower spending pace would provide room for assessing better whether the new procedures set in place to guarantee efficiency are working. Likewise, a wider resort to user fees for public services would help rationalize demand and reduce strains on the budget.

40. Monetary policy should continue to tighten to contain the pace of domestic demand as the external outlook improves, and facilitate a soft landing scenario. With the estimated output gap small, recovery momentum building, and the restraining effects of low import price inflation receding, CPI inflation is set to rise gradually above target. This calls for raising rates preemptively. The case for tightening is reinforced by the ebullience of the housing and household debt markets. 
41. An "early but gradual" strategy of rate increases is needed. The increased sensitivity of the debt servicing burden to base rate changes, the potential vulnerability of a segment of borrowers to rate hikes, and, more generally, the increased uncertainty on the response of consumption to interest rate increases call for gradual, and correspondingly early, increases in rates. Against this backdrop, the November and February rate hikes of 25 bps were appropriate. Looking ahead, if and as the baseline unfolds, rates should steadily be raised in small steps.

\section{The MPC's forward looking approach is well-equipped to deal with the} challenges posed by the change in the inflation target. With CPI inflation running well below its new target, the change seems to pose a greater challenge for monetary policy in communicating rate hikes. But, the forward looking-orientation of monetary policy, focused on inflation forecasts rather than outcomes, is now broadly accepted and provides a strong basis for explaining the need to raise rates preemptively in a cyclical upswing.

\section{A key challenge is to ensure adequate provision of pensions as the population} ages. The authorities' approach to facing the challenge of population aging, centered on the goal of raising the share of pensioners' incomes from private sources, remains appropriate. But the viability of this approach depends on whether people are saving enough and indications are that this may not be the case. This increases the risk that public pension liabilities may be higher than currently projected. The establishment of a Pension Commission, in charge of monitoring developments in this area and recommending corrective actions if needed, is thus appropriate.

\section{The publication of Treasury's assessment of the five tests for EMU entry is} welcome. It clarifies the government's position and represents a major analytical contribution to the debate on this critical decision. The next assessment could benefit from further work on some difficult issues that are key to the entry decision (such as the long-term implications of entering before full convergence has been attained, the benchmarks to be used to assess whether flexibility is sufficient, and some costs of delaying entry). Among the initiatives launched by the authorities to follow up on the assessment, the reviews of the working of the housing and household debt markets are particularly timely.

\section{The authorities' policy agenda to boost productivity and promote employment} properly encompasses a variety of fronts, but should be reassessed regularly. This would allow streamlining or scrapping ineffective programs. Some active labor market initiatives, such as the New Deal for 18-24-year olds, have succeeded, partly because they strengthened job search incentives. Other New Deal programs would benefit from a similar strengthening. The various ongoing initiatives to boost productivity should also be monitored closely with the goal of streamlining them as needed.

46. As reported in the 2002 FSAP, the UK financial supervisory framework is in many aspects at the forefront internationally and the banking system is sound. Looking forward, the possibility of a decline in mortgage collateral values deserves special vigilance. Also, as credit growth decelerates, compressed margins may erode profitability — although 
from high levels. The current reform of insurance supervision and regulation will strengthen the sector and minimize the risk of future systemic stress. Reforms in the settlement and payment systems have further reinforced their safeguards and efficiency.

\section{The United Kingdom's strong stand in favor of trade liberalization is}

commendable. Efforts to reform CAP, reintroduce momentum in Doha round negotiations, and increase the effective access of less developed countries to industrial country markets should be maintained. While the ongoing increase in ODA spending is welcome, the UN target of 0.7 percent of GDP remains distant.

48. The further strengthening of the United Kingdom's AML/FT legislation is welcome.

49. It is proposed that the next Article IV consultation be held on the standard 12-month cycle. 
Figure 1. United Kingdom: The Economy Has Weathered the Global Slowdown Well

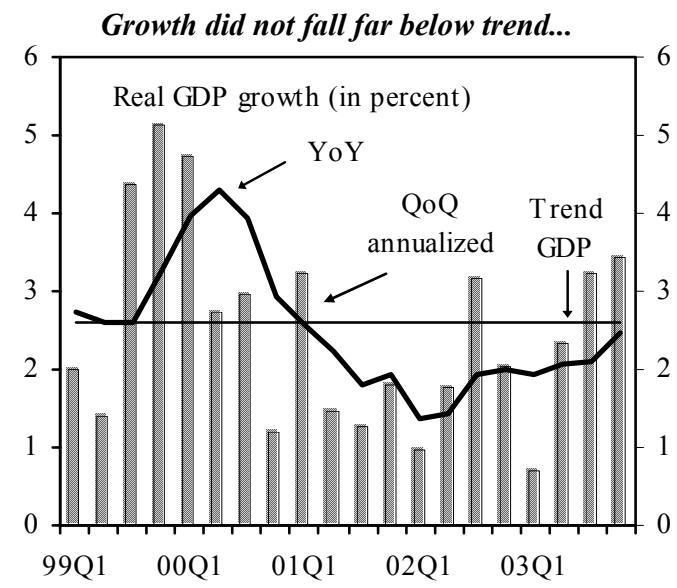

But private investment also did not fall as much as in the U.S....
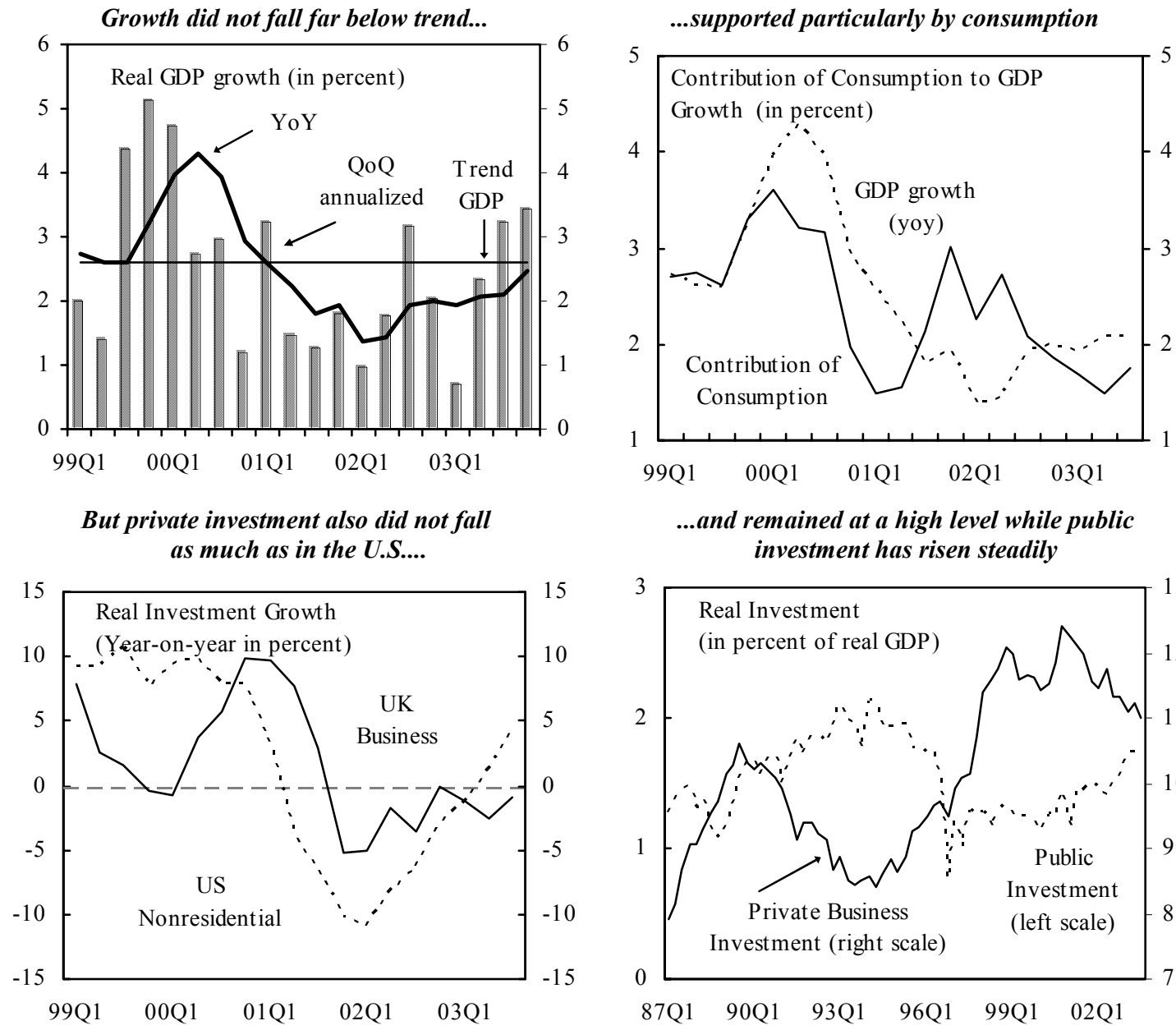

....and remained at a high level while public investment has risen steadily

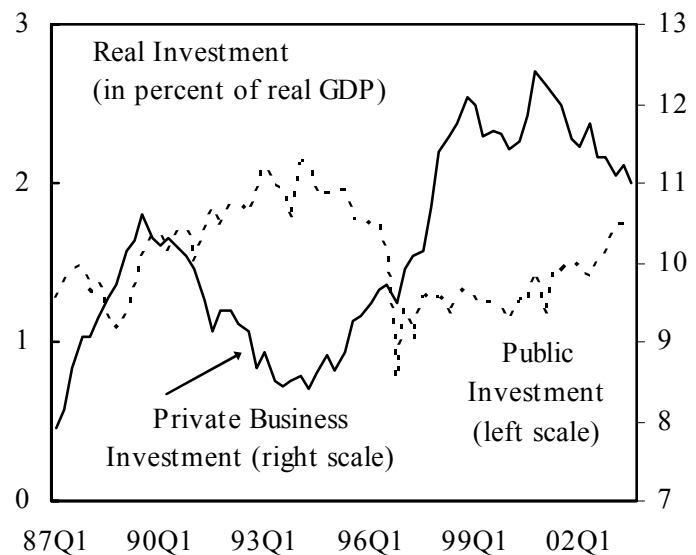

The trade balance has deteriorated but the current account by less

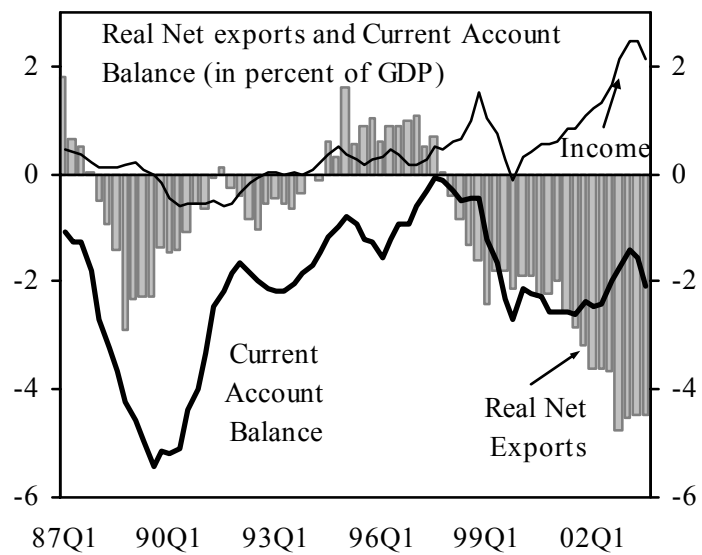

Survey indicators suggest an imminent acceleration in growth

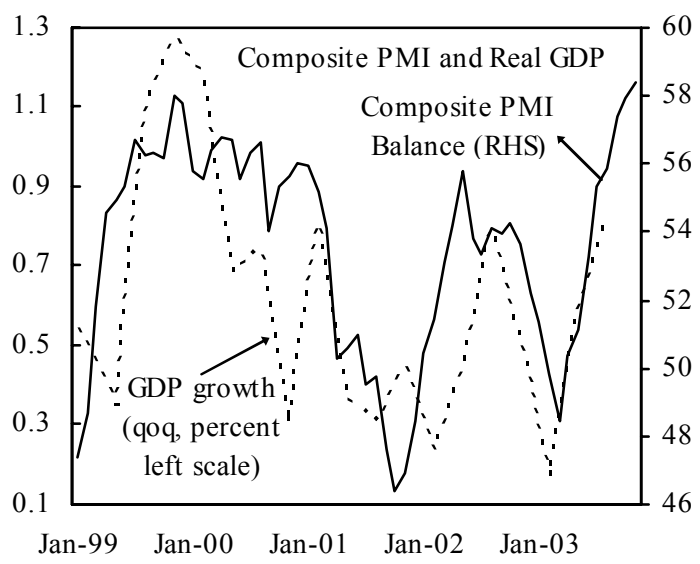

Source: Office of National Statistics (ONS). 
Figure 2. United Kingdom: Financial Markets are Pricing in an Upswing

Equity markets have moved closely with U.S. markets

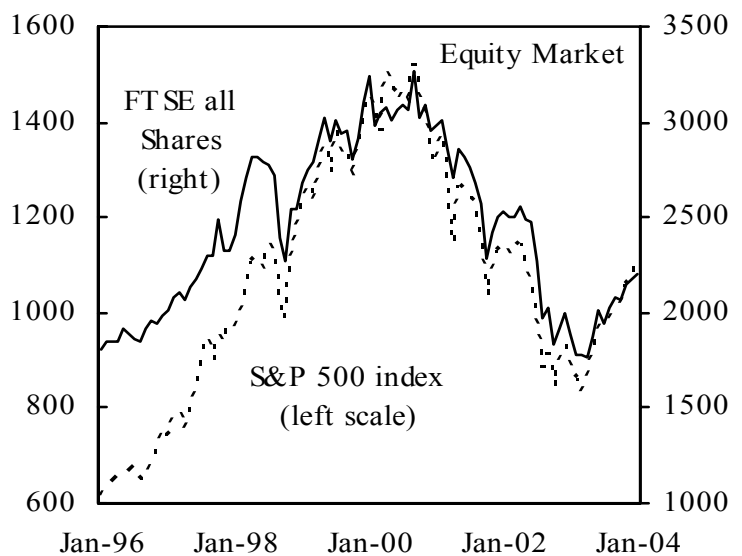

with a particularly notable widening

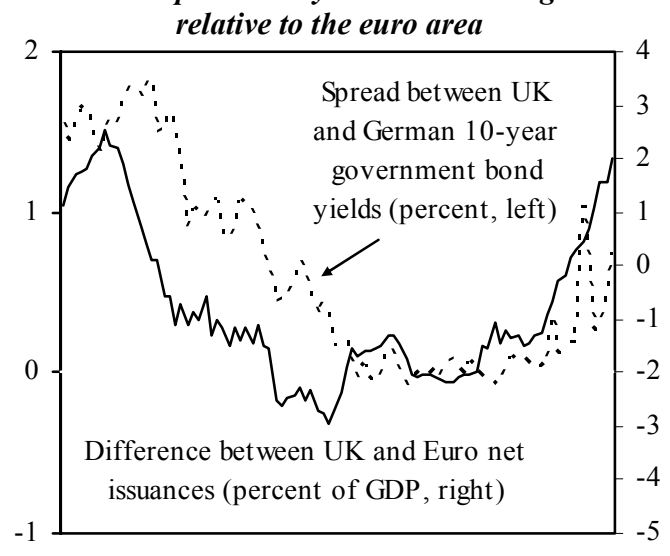

Jan-96 Jan-98 Jan-00 Jan-02

Sterling has moved inversely against the dollar and the euro...

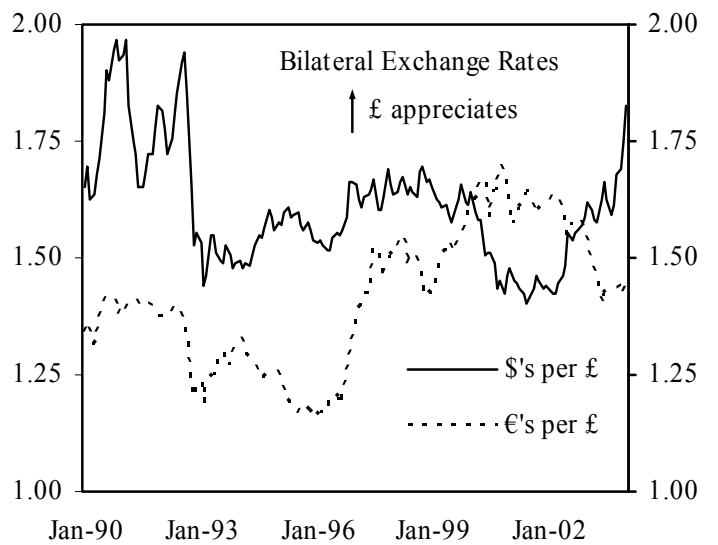

Bond yields have risen

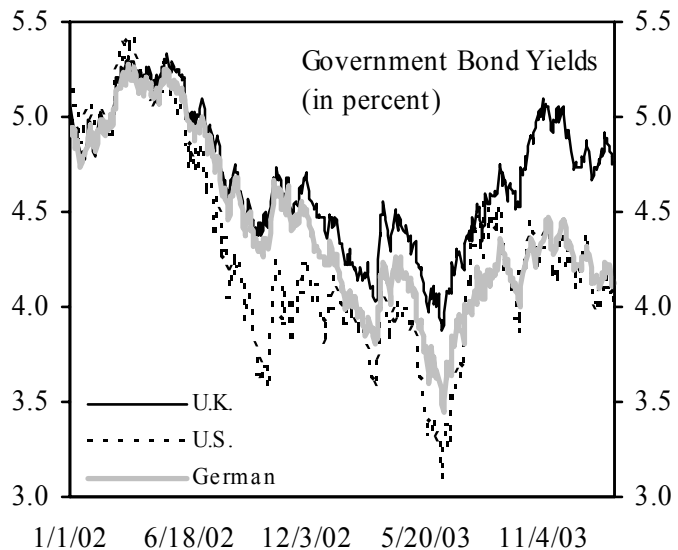

Mortgage rates are near historic lows

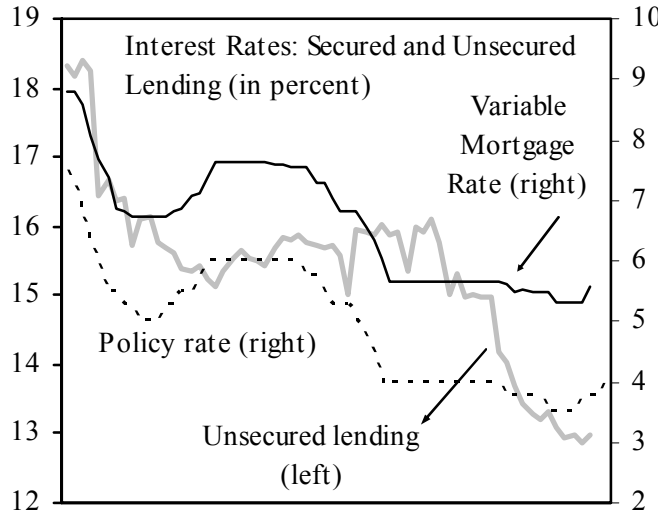

Sep-98 Sep-99 Sep-00 Sep-01 Sep-02 Sep-03

....and depreciated on an effective basis last year but has been recovering

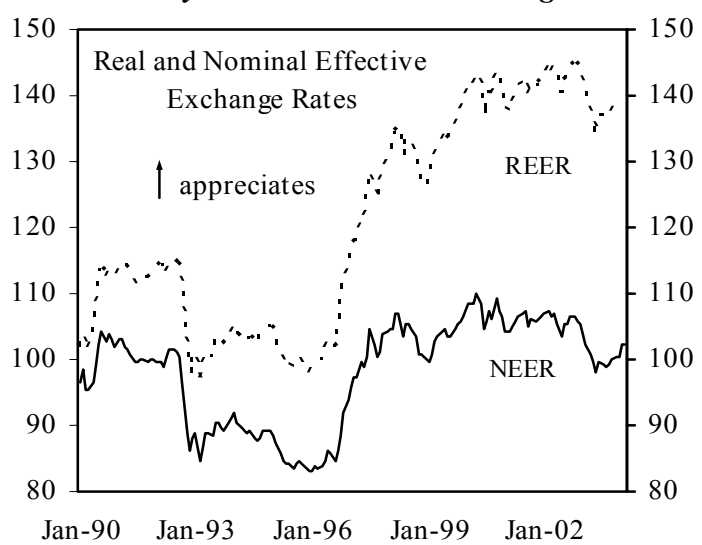

Sources: Bank of England; and Office of National Statistics (ONS). 
Figure 3. United Kingdom: Household Balance Sheets are Important for Consumption

The inverse association between savings and house prices in the U.K....

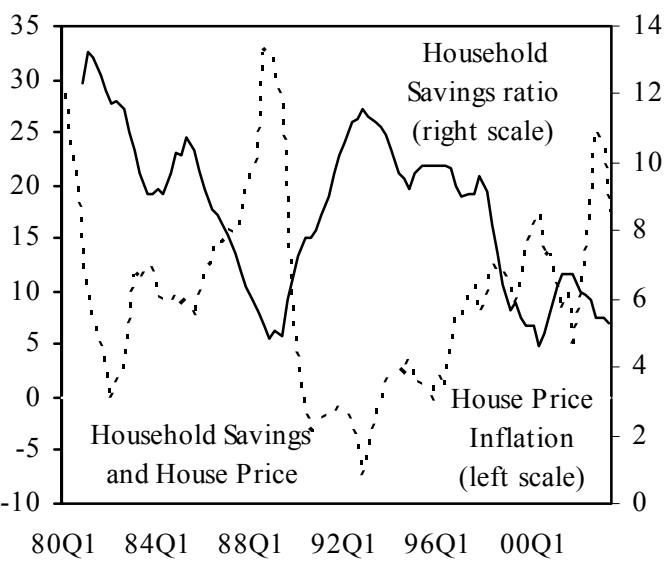

Mortgage equity withdrawals are running high

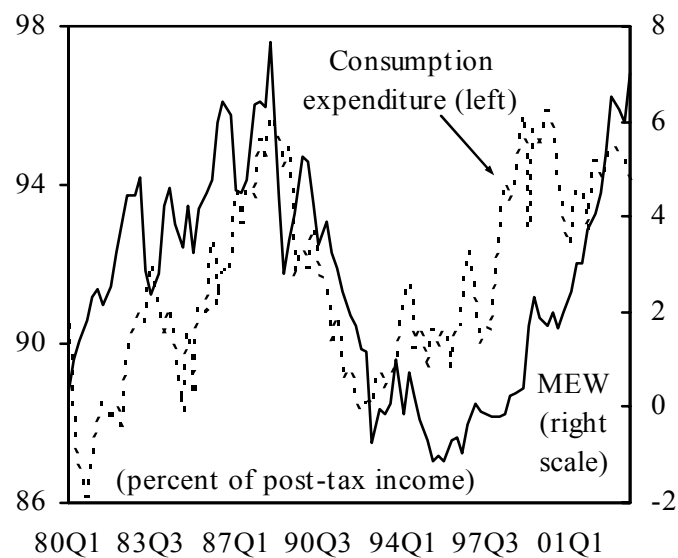

...but household debt has also risen sharply...

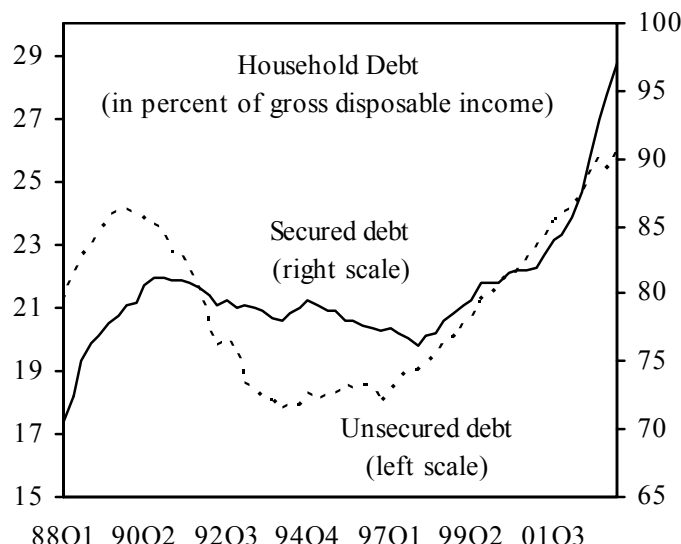

...indicates the importance of wealth for consumption

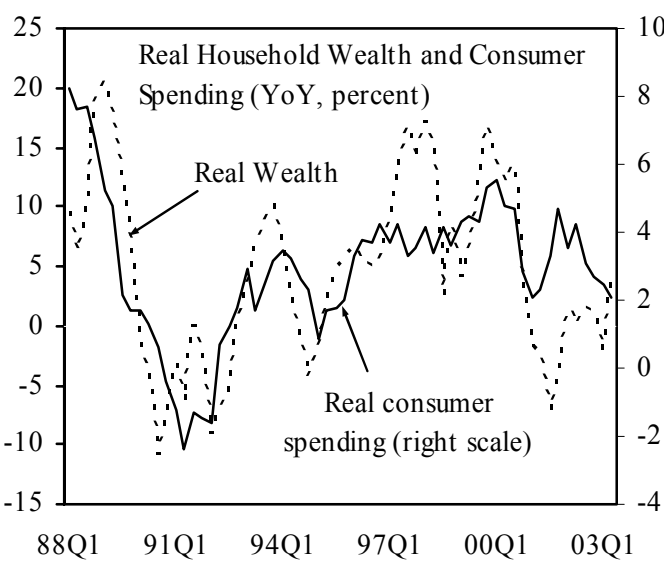

Increases in housing equity have offset declines in financial assets...

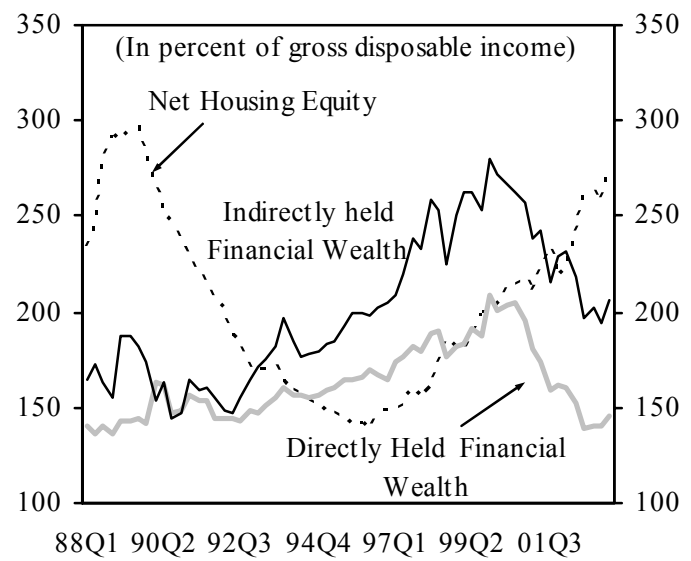

...though low interest payments imply income gearings remains low

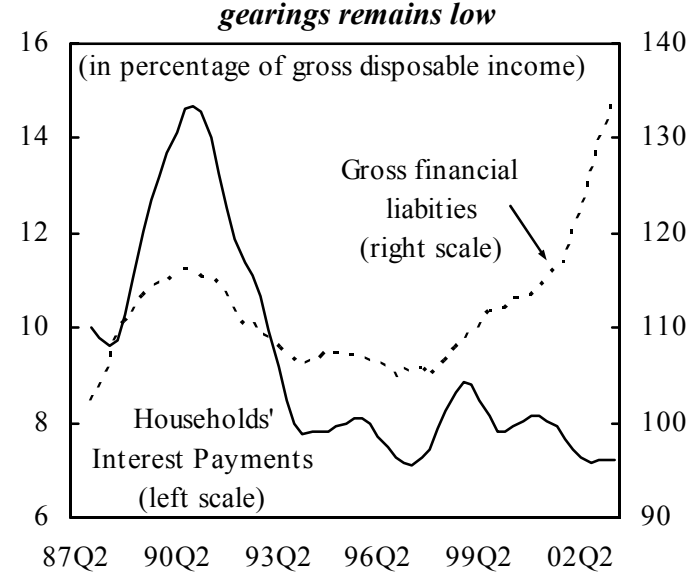

Source: Office of National Statistics (ONS). 
Figure 4. United Kingdom: The Labor Market Has Been Remarkably Resilient During the Slowdown

\section{Unemployment remains near a 20-year low}

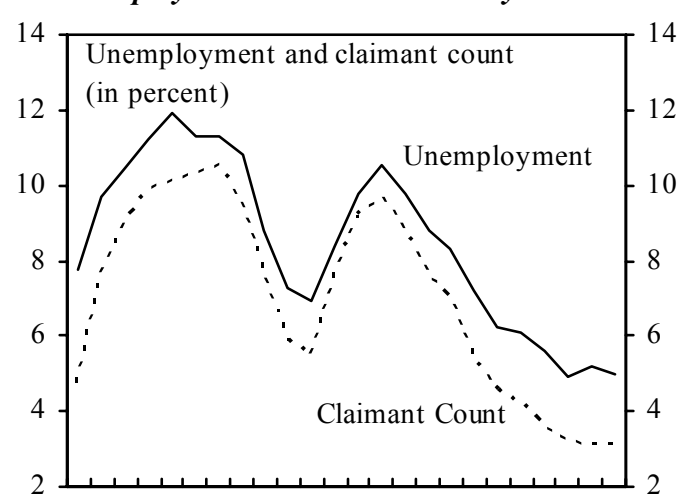

$\begin{array}{llllllllllll}80 & 82 & 84 & 86 & 88 & 90 & 92 & 94 & 96 & 98 & 00 & 02\end{array}$
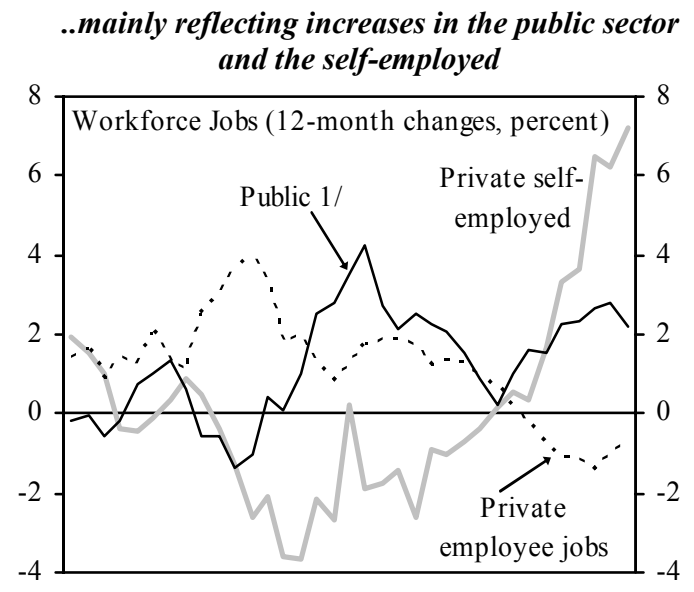

95Q1 96Q2 97Q3 98Q4 00Q1 01Q2 02Q3

...as well as in private sector earnings...

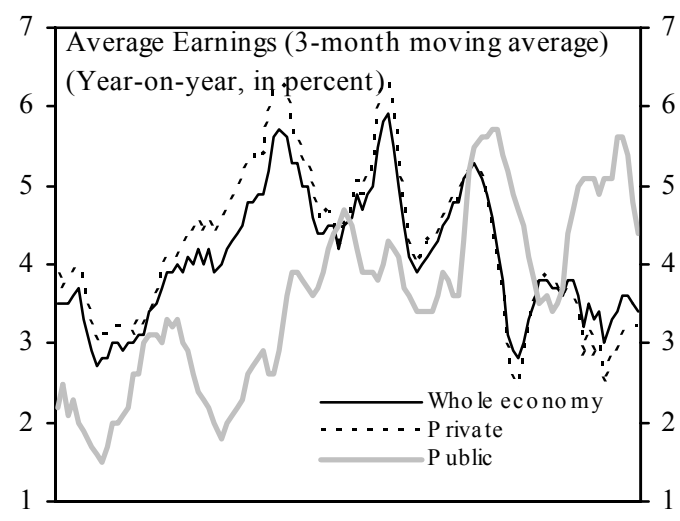

Jan-95 Jan-97 Jan-99 Jan-01 Jan-03
Employment has continued to grow...

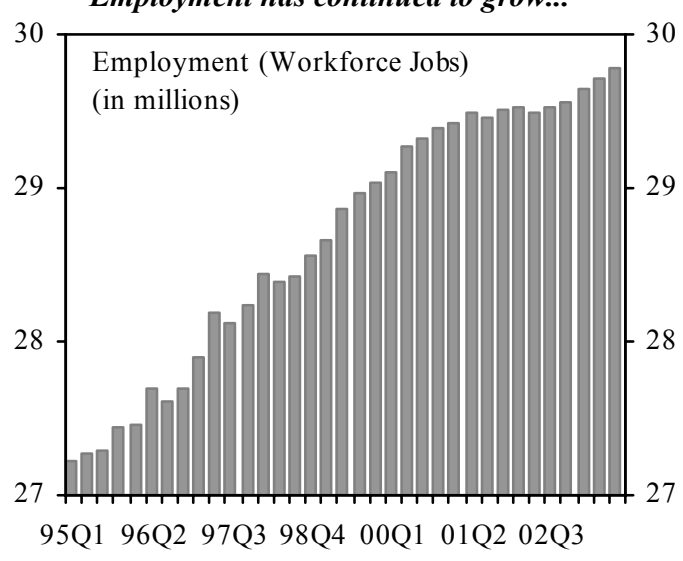

Adjustment has come in hours worked...

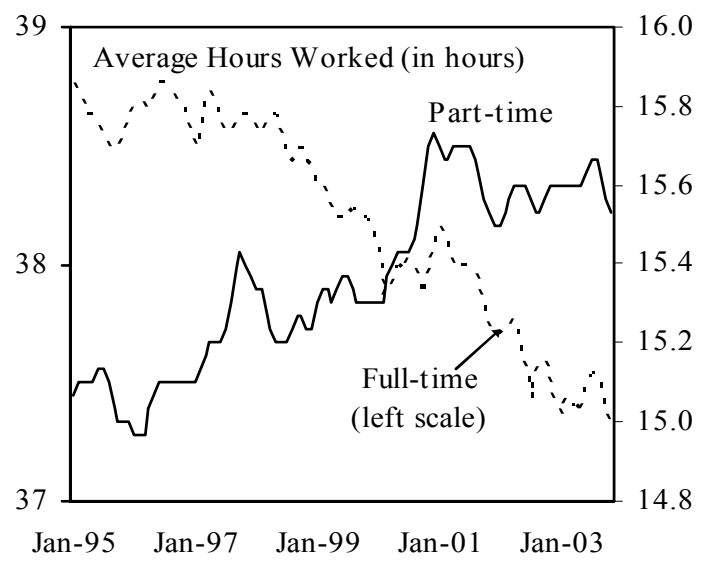

...and unit labor cost growth has eased significantly

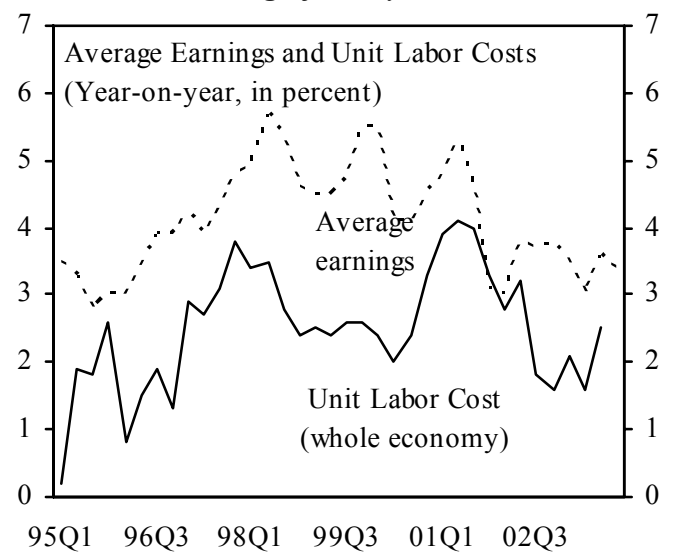

Source: Office of National Statistics (ONS).

1/ Public administration, education and health which, used as a proxy for public employment. 
Figure 5. United Kingdom: The Housing Market Remains Robust

Housing boom bust cycles have long been a feature of the U.K.

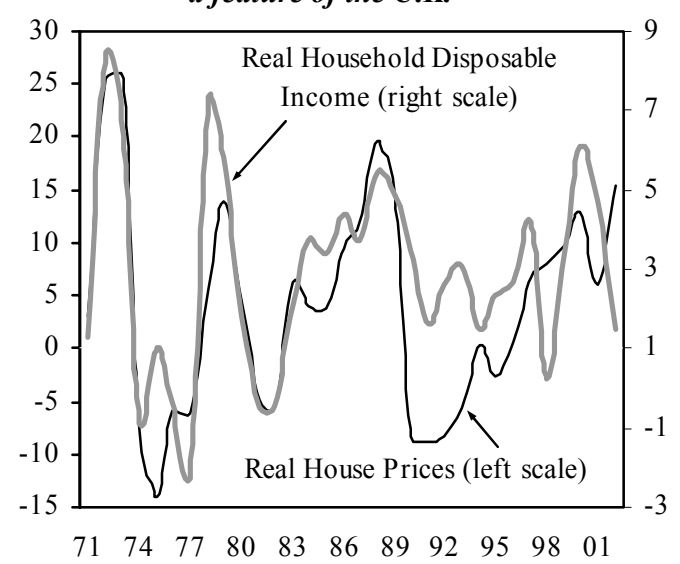

...and some measures..

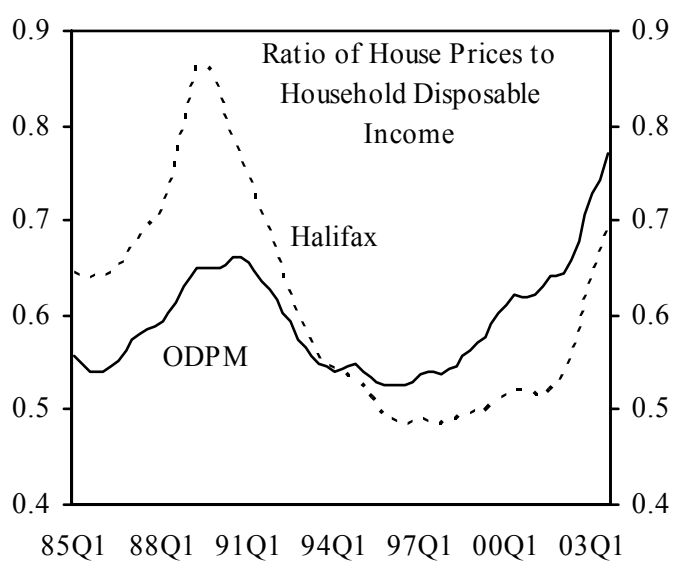

The resilient labor market has supported credit quality

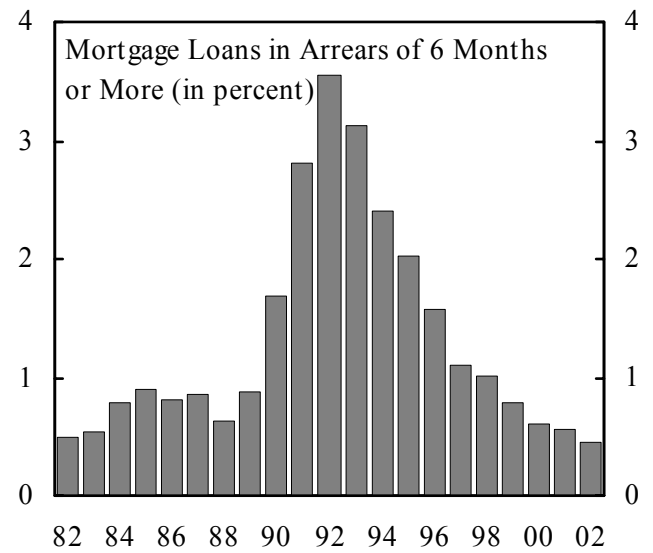

Prices are at a new peak relative to trend...

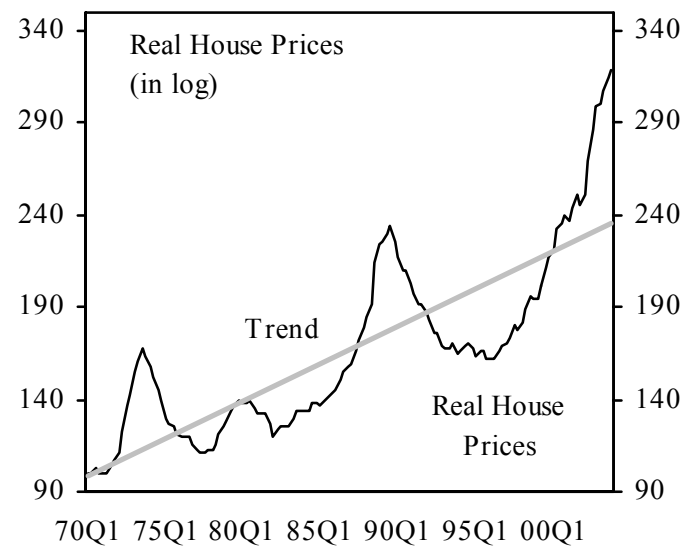

...of affordability

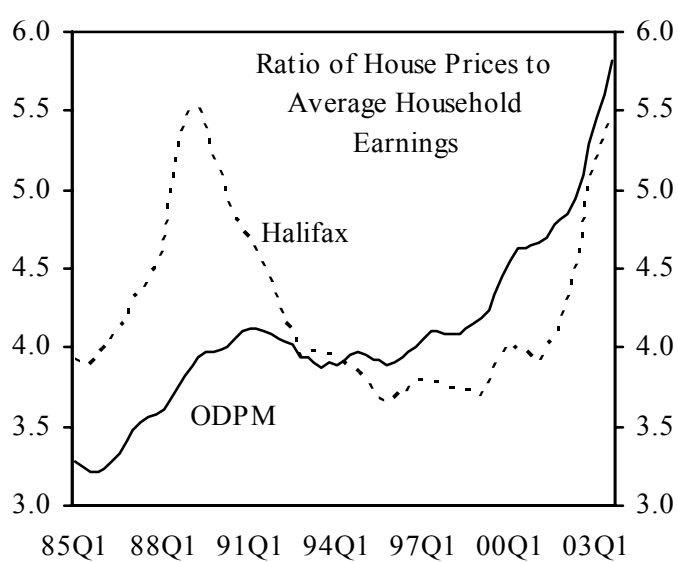

Survey indicators suggest house price inflation is set to rise again

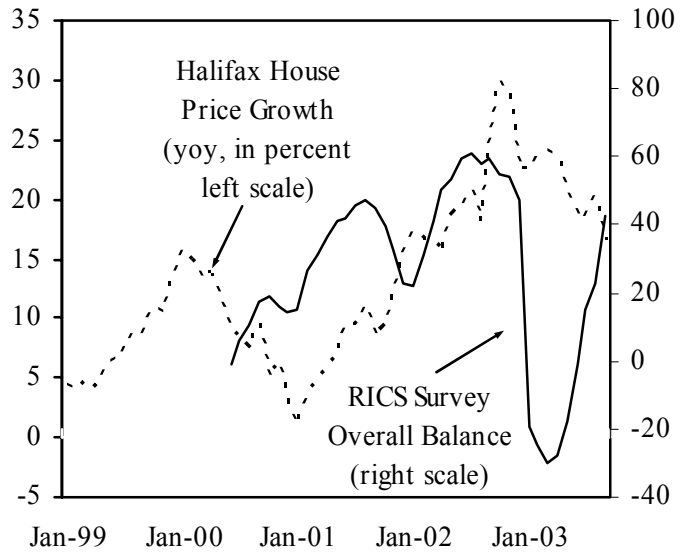

Sources: Bank of England; Halifax; ODPM; and Office of National Statistics (ONS). 
Figure 6. United Kingdom: Inflation Has Remained Close to Target

RPIX Inflation has been within a $1 / 2$ percentage point of target

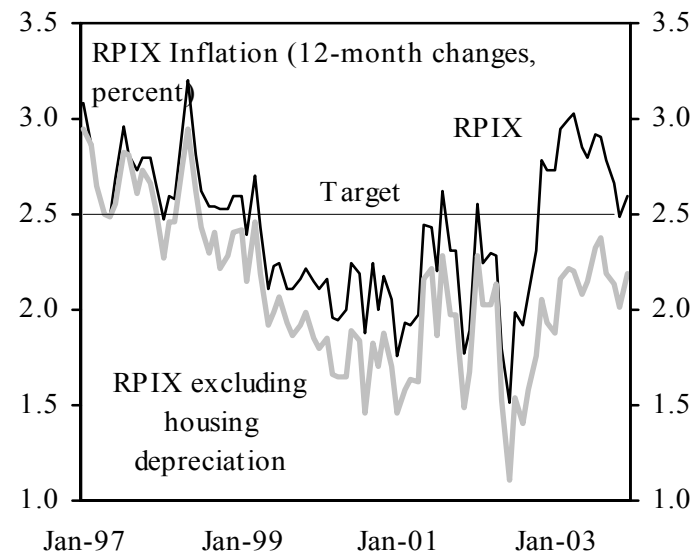

The impact of falling import prices is waning

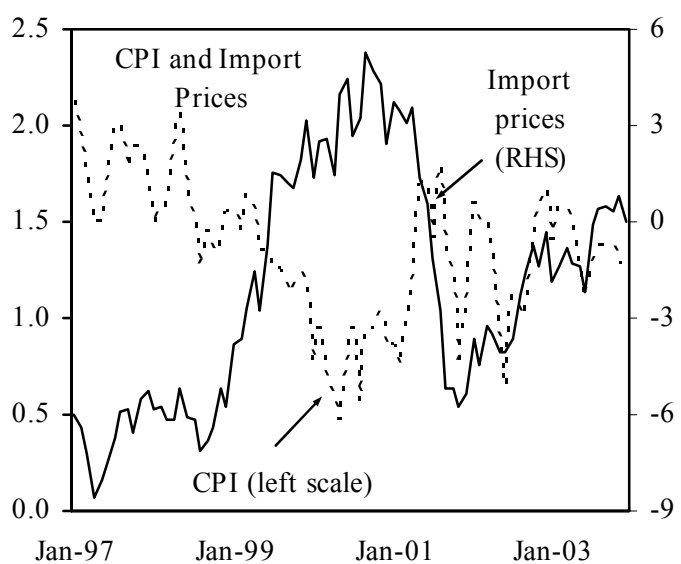

Public sector deflators are rising rapidly

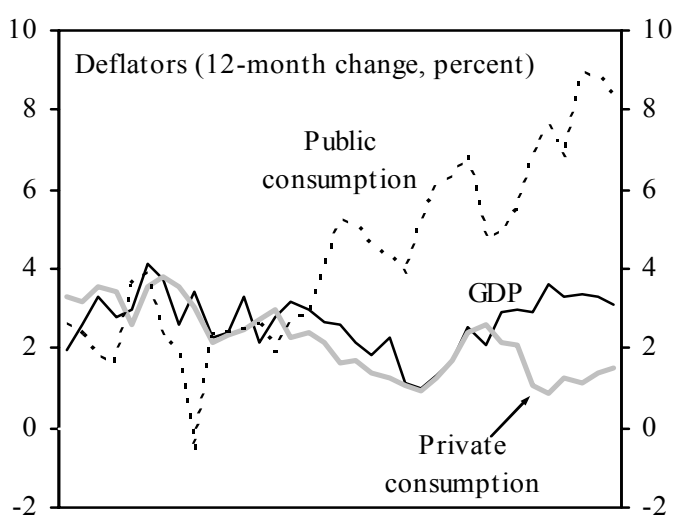

95Q1 96Q2 97Q3 98Q4 00Q1 01Q2 02Q3
Services inflation has decelerated and goods inflation picked up

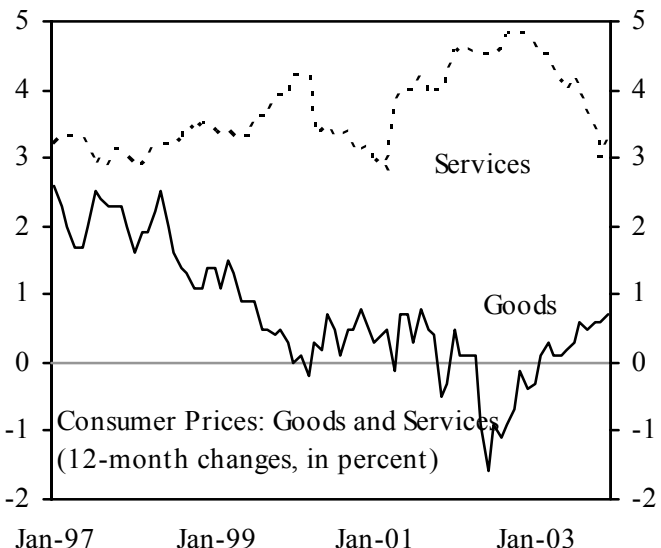

Producer prices inflation has recovered

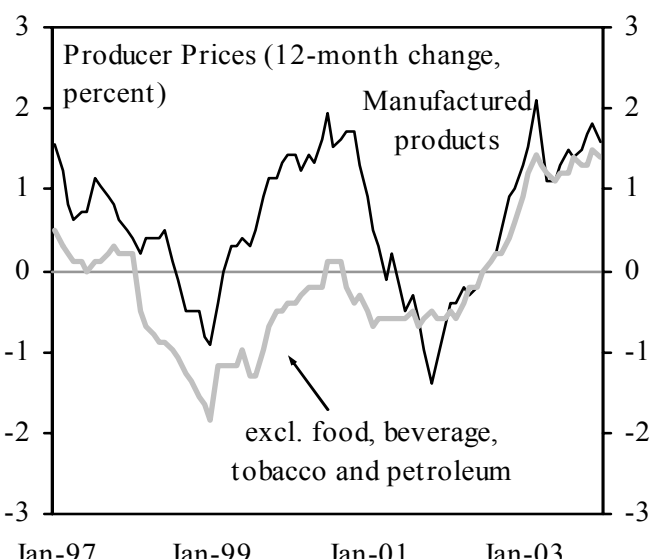

The gap between RPIX and CPI inflation is high

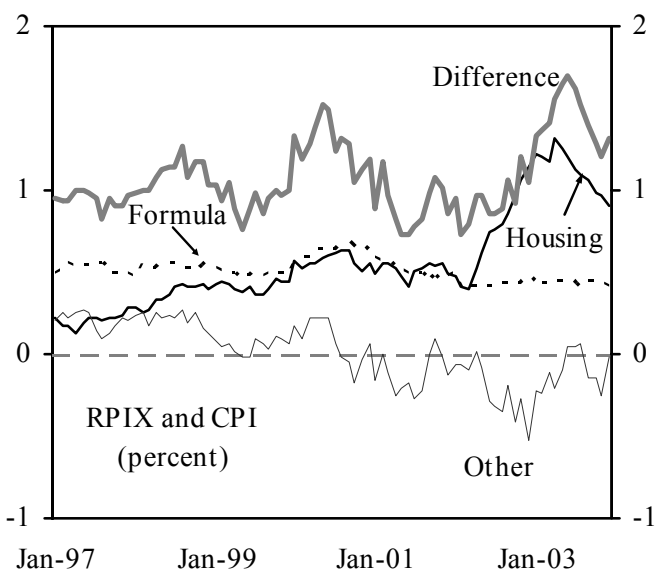

Sources: Bank of England; and Office of National Statistics (ONS). 
Figure 7. United Kingdom: The Monetary Policy Stance Has Been Expansionary

Early easing during the downturn ...

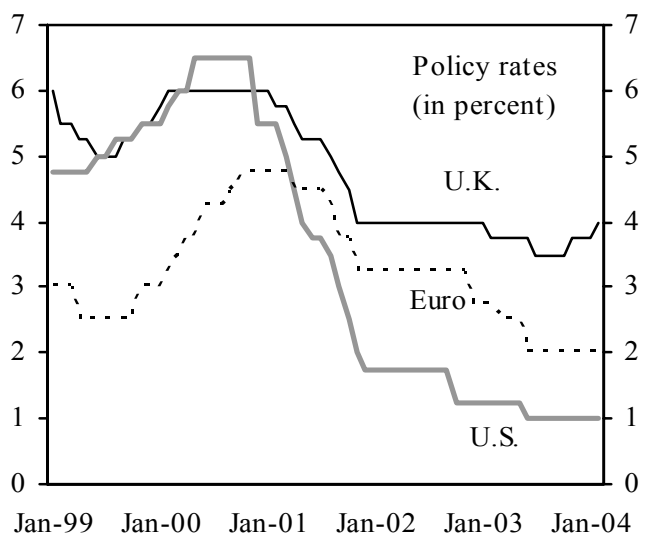

...while high credibility has anchored inflation expectations

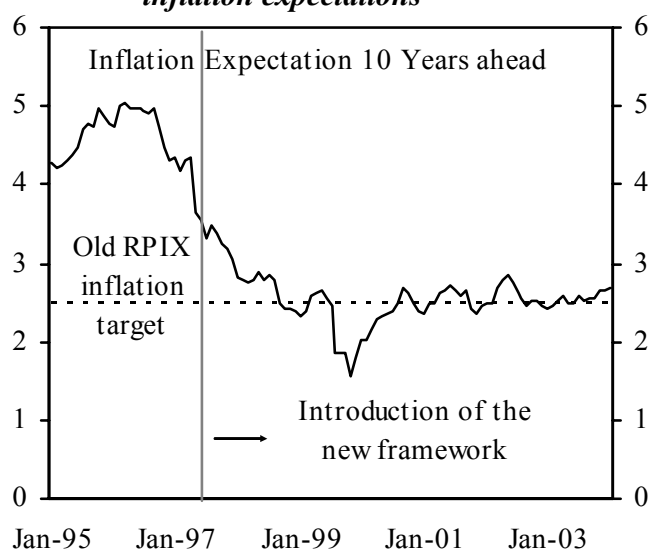

Headline inflation is projected to rise

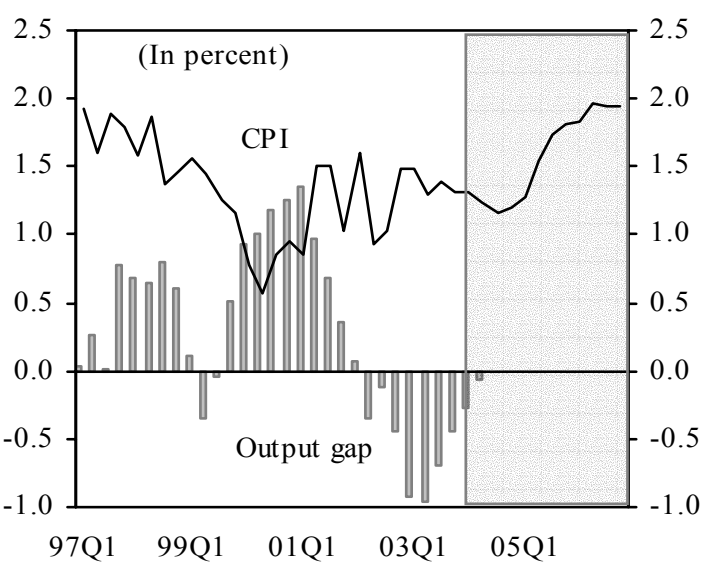

...helped limit the build up of slack..

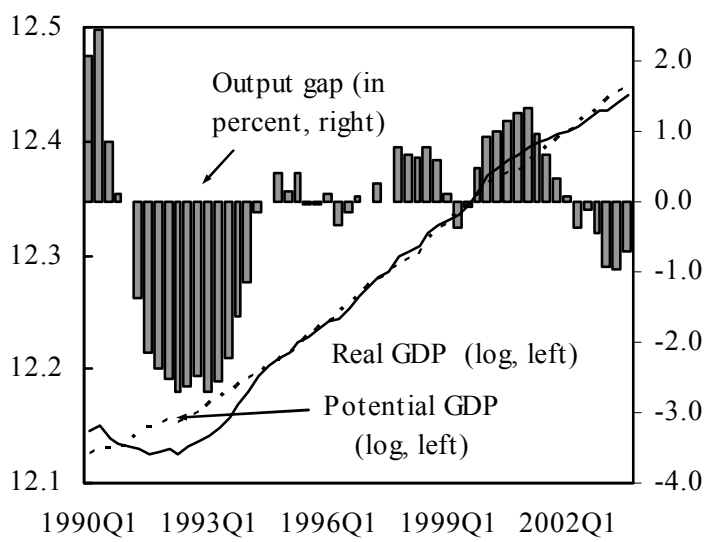

The easing has been particularly notable relative to nominal GDP

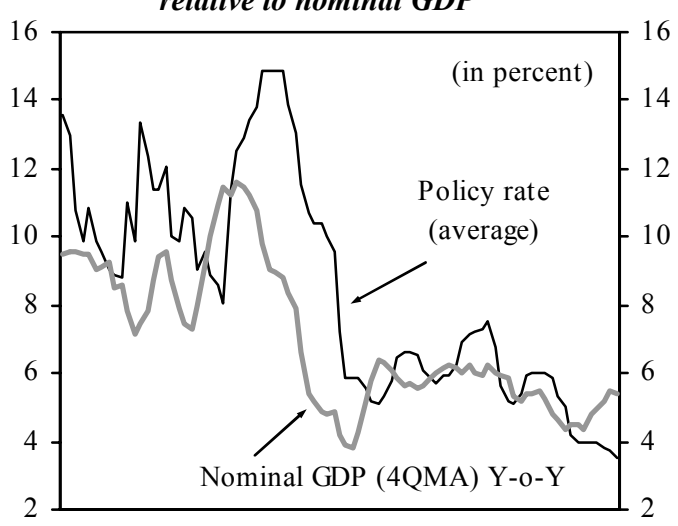

82Q1 85Q1 88Q1 91Q1 94Q1 97Q1 00Q1 03Q1

The responsiveness of the debt service burden

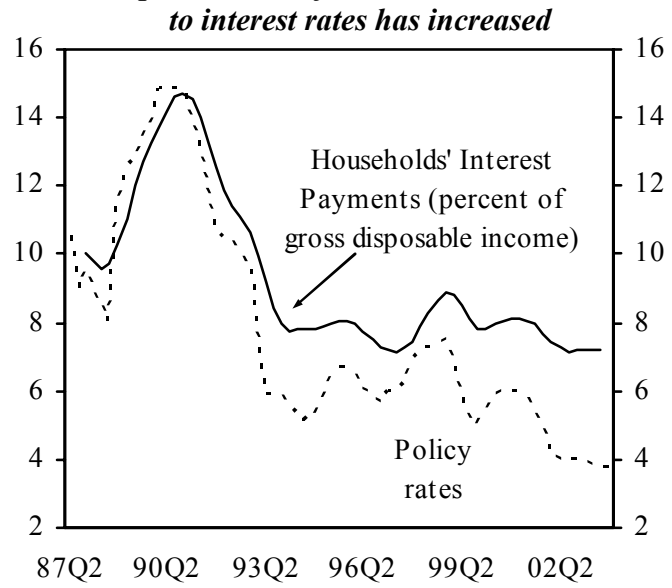

Sources: Bank of England; and Office of National Statistics (ONS). 
Figure 8. United Kingdom: The Fiscal Balances are Deteriorating

The overall balance is projected to remain in deficit...

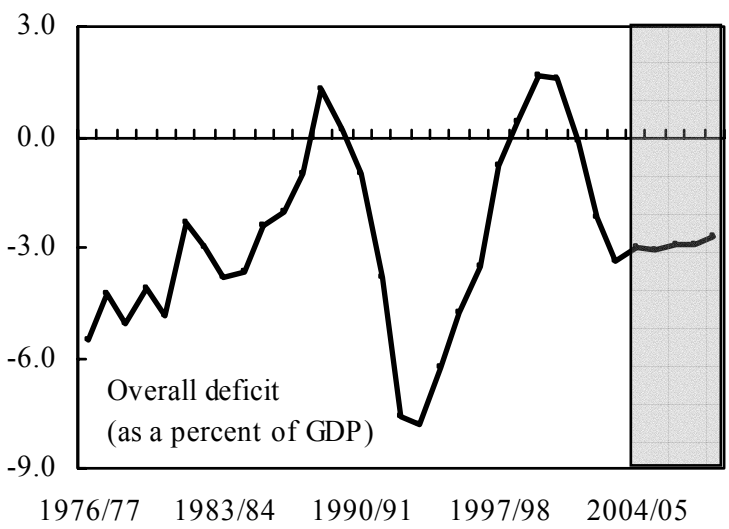

and a negative current balance, reflecting...
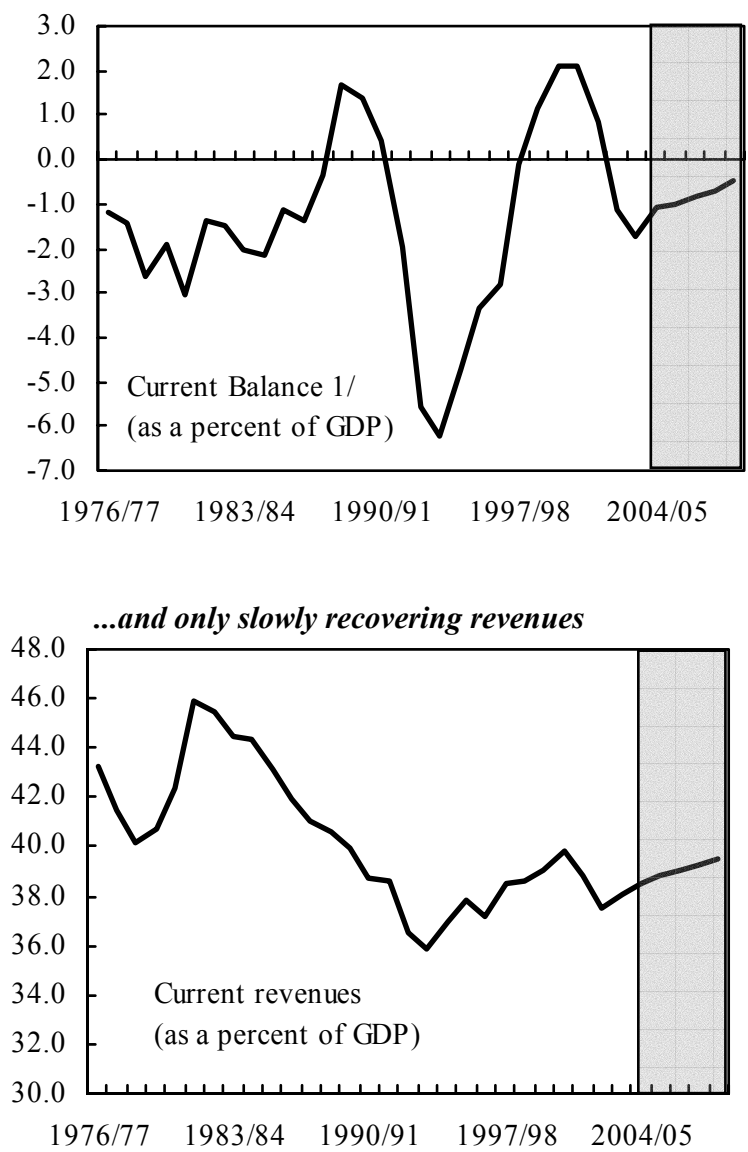

...due to higher net investment...

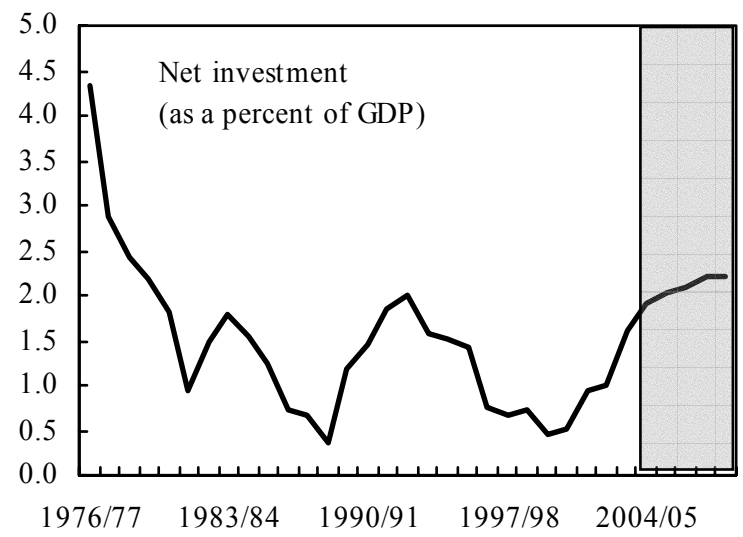

...increasing current expenditures...

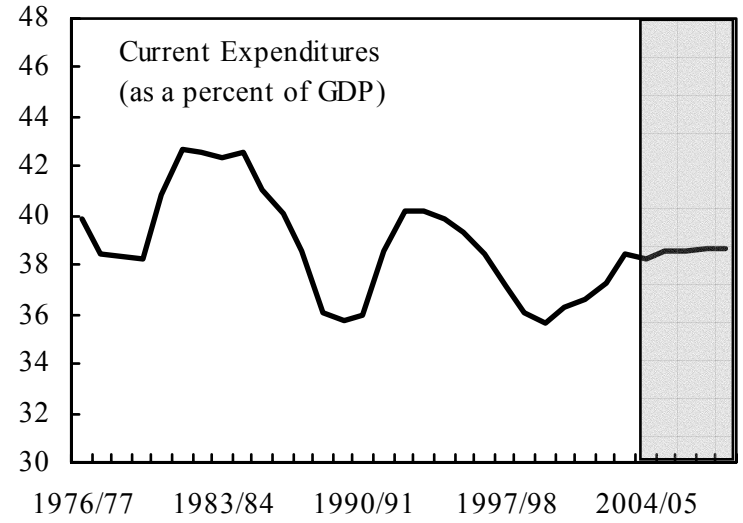

Public net debt is expected to rise from a low level

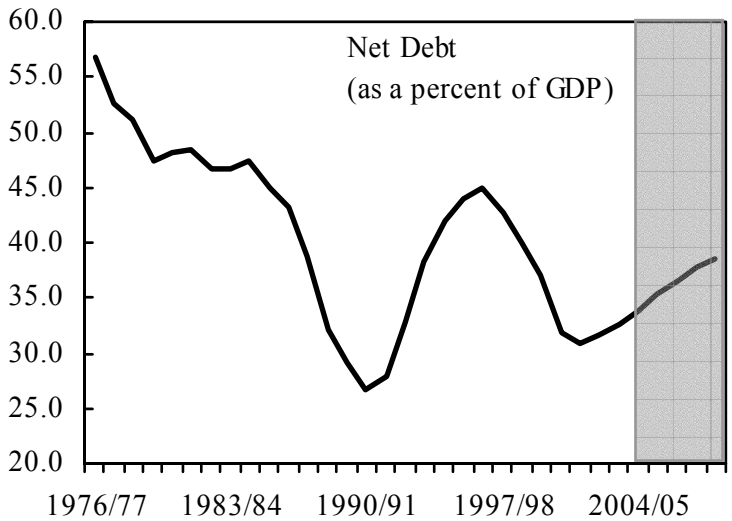

Sources: HM Treasury, ONS, and staff estimates. $1 /$ Including depreciation. 
Figure 9. United Kingdom: Spending in Key Sectors is on the Rise

Following years of comparatively low spending on health...

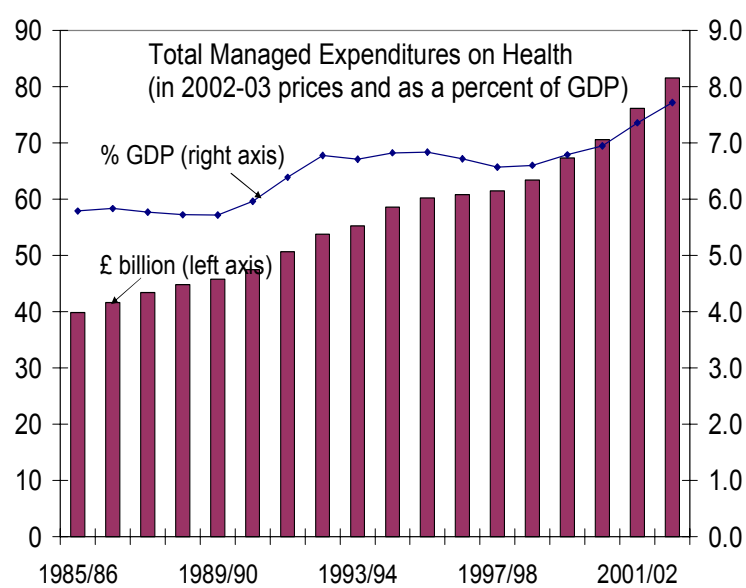

....and on transport,

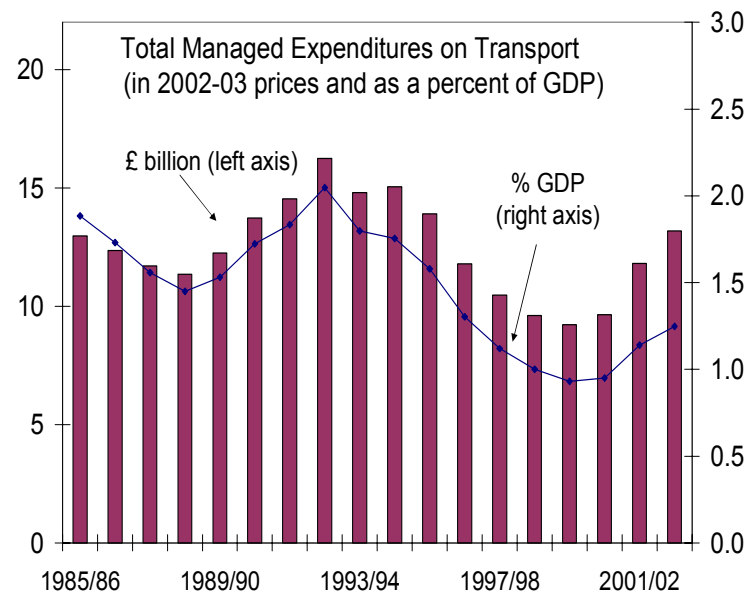

Source: HM Treasury ...on education...

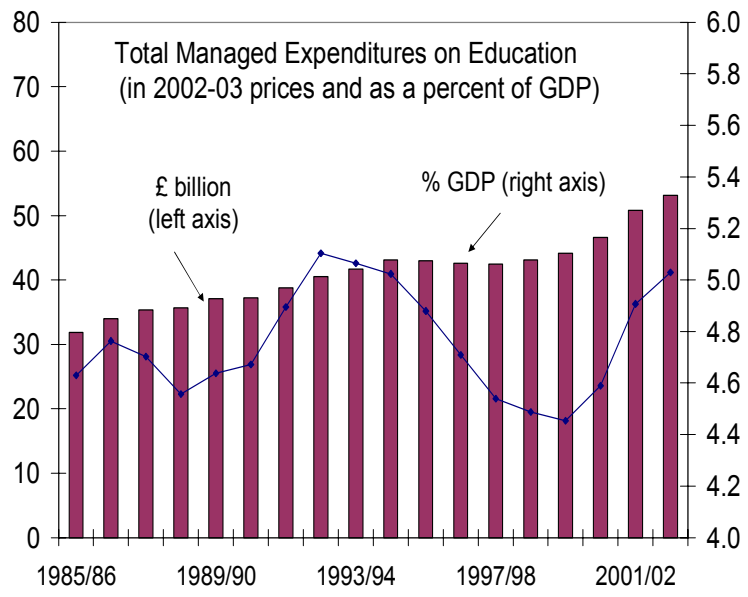

...spending in these sectors has been rising

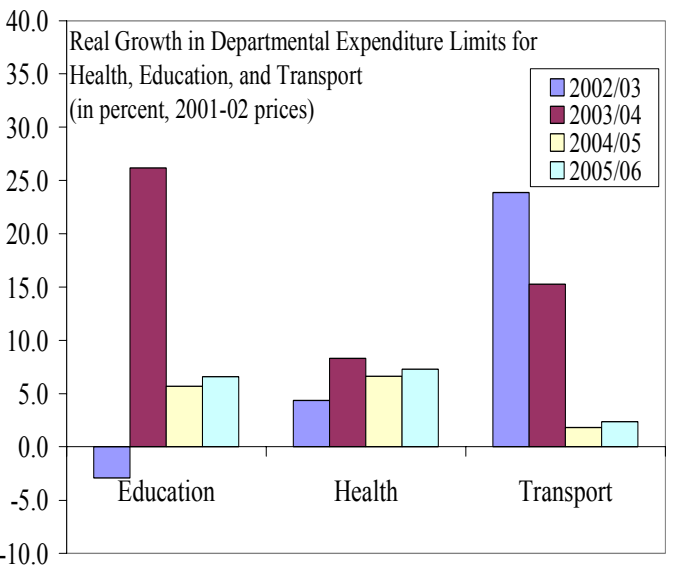


Table 1. United Kingdom: Selected Economic Indicators

\begin{tabular}{|c|c|c|c|c|c|c|}
\hline & 1999 & 2000 & 2001 & 2002 & $\begin{array}{r}2003 \\
\text { Est. }\end{array}$ & $\begin{array}{l}2004 \\
\text { Proj. }\end{array}$ \\
\hline \multicolumn{7}{|l|}{ Real Economy (change in percent) } \\
\hline Real GDP & 2.8 & 3.8 & 2.1 & 1.7 & 2.1 & 3.1 \\
\hline Domestic demand & 3.8 & 3.8 & 2.7 & 2.8 & 2.5 & 3.4 \\
\hline CPI (average, harmonized price index) & 1.4 & 0.8 & 1.2 & 1.3 & 1.3 & 1.5 \\
\hline Unemployment rate (in percent) $1 /$ & 6.0 & 5.5 & 5.1 & 5.2 & 5.0 & 5.0 \\
\hline Gross national saving (percent of GDP) & 15.1 & 15.0 & 14.7 & 14.7 & 14.3 & 14.6 \\
\hline Gross domestic investment (percent of GDP) & 17.8 & 17.5 & 17.1 & 16.5 & 16.5 & 16.4 \\
\hline \multicolumn{7}{|l|}{ Public Finance (fiscal years) 2/ } \\
\hline General government balance & 1.7 & $4.13 /$ & 0.0 & -2.0 & -3.1 & -2.9 \\
\hline Public sector balance & 1.7 & $3.93 /$ & -0.1 & -2.2 & -3.4 & -3.0 \\
\hline Public sector cyclically adjusted balance 4/ & 1.7 & 1.3 & -0.4 & -2.0 & -2.9 & -2.9 \\
\hline Public sector net debt & 37.1 & 31.9 & 31.0 & 31.6 & 32.7 & 33.9 \\
\hline \multicolumn{7}{|c|}{ Money and Credit (end-period, 12-month percent change) } \\
\hline M0 & 11.6 & 4.3 & 8.2 & 5.9 & 7.4 & $\ldots$ \\
\hline M4 & 4.3 & 8.2 & 6.6 & 7.3 & $7.05 /$ & $\ldots$ \\
\hline Consumer credit & 14.5 & 12.2 & 14.0 & 15.1 & $13.05 /$ & $\ldots$ \\
\hline \multicolumn{7}{|l|}{ Interest Rates (year average) } \\
\hline Three-month interbank rate & 6.0 & 5.8 & 4.1 & 4.0 & 3.7 & $\ldots$ \\
\hline Ten-year government bond yield & 5.4 & 4.8 & 5.0 & 4.4 & 4.9 & $\ldots$ \\
\hline \multicolumn{7}{|l|}{ Balance of Payments } \\
\hline Trade balance (in percent of GDP) & -1.8 & -2.1 & -2.8 & -3.0 & -3.1 & -2.0 \\
\hline Current account balance (in percent of GDP) & -2.7 & -2.5 & -2.4 & -1.7 & -2.2 & -1.8 \\
\hline $\begin{array}{l}\text { Reserves (national valuation of gold, } \\
\text { end of period, in billions of SDRs) }\end{array}$ & 30.5 & 37.0 & 32.2 & 31.5 & 26.5 & ... \\
\hline \multicolumn{7}{|l|}{ Fund Position (as of December 31, 2003) } \\
\hline Holdings of currency (in percent of quota) & & & & & & 60.4 \\
\hline Holdings of SDRs (in percent of allocation) & & & & & & 13.3 \\
\hline Quota (in millions of SDRs) & & & & & & $10,738.5$ \\
\hline \multicolumn{7}{|l|}{ Exchange Rates } \\
\hline Exchange rate regime & & & & \multicolumn{2}{|c|}{ Floating } & \\
\hline Present rate (January 30,2004$)$ & & & & \multicolumn{2}{|c|}{$\mathrm{US} \$=£ 0.548$} & \\
\hline Nominal effective rate $(1995=100) 6 /$ & 122.3 & 126.8 & 124.7 & 125.0 & 118.1 & $\ldots$ \\
\hline Real effective rate $(1995=100) 6 / 7 /$ & 133.7 & 141.0 & 140.7 & 143.4 & $137.75 /$ & $\ldots$ \\
\hline \multicolumn{7}{|c|}{$\begin{array}{l}\text { Social Indicators (reference year, and unless otherwise indicated, percentage of EU-15 average in parentheses): } \\
\text { GDP per capita (in current PPP US dollars, 2001): 25,400 (101 percent); Income distribution (ratio of income } \\
\text { received by top and bottom quintiles, 1999): } 5.5 \text { (4.6); Life expectancy at birth (2001): } 75.7 \text { (male) and } \\
80.4 \text { (female); Automobile ownership (1999): } 420 \text { per thousand ( } 92.8 \text { percent); CO2 emissions (ton per } \\
\text { capita, 2000): } 8.9 \text { (106 percent); Population density (2000): } 244 \text { inhabitants per sq. km (210 percent). }\end{array}$} \\
\hline
\end{tabular}

Sources: National Statistics; HM Treasury; Bank of England; International Financial Statistics; INS; and IMF staff estimates.

1/ ILO unemployment; based on Labor Force Survey data.

2/ The fiscal year begins in April.For example, fiscal balance data for 2002 refers to FY2002/03. Debt stock data refers to

the end of the fiscal year.

3/ Includes the auction proceeds of spectrum licenses (2.4 percentage points of GDP) in 2000/01.

4/ Staff estimates.

5/ As of November 2003.

6/ An increase denotes an appreciation.

7/ Based on relative normalized unit labor costs in manufacturing. 


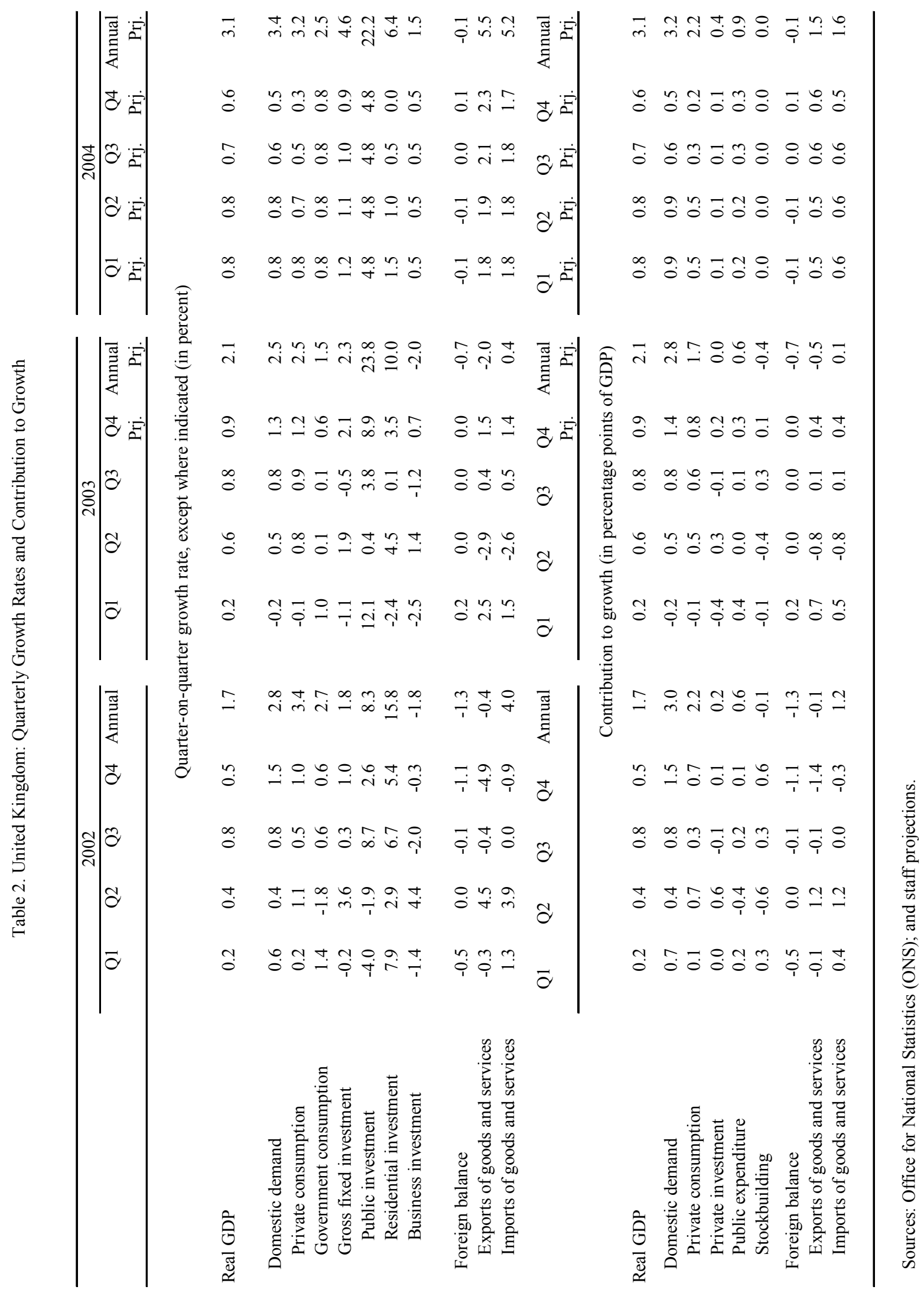


Table 3. United Kingdom: Balance of Payments

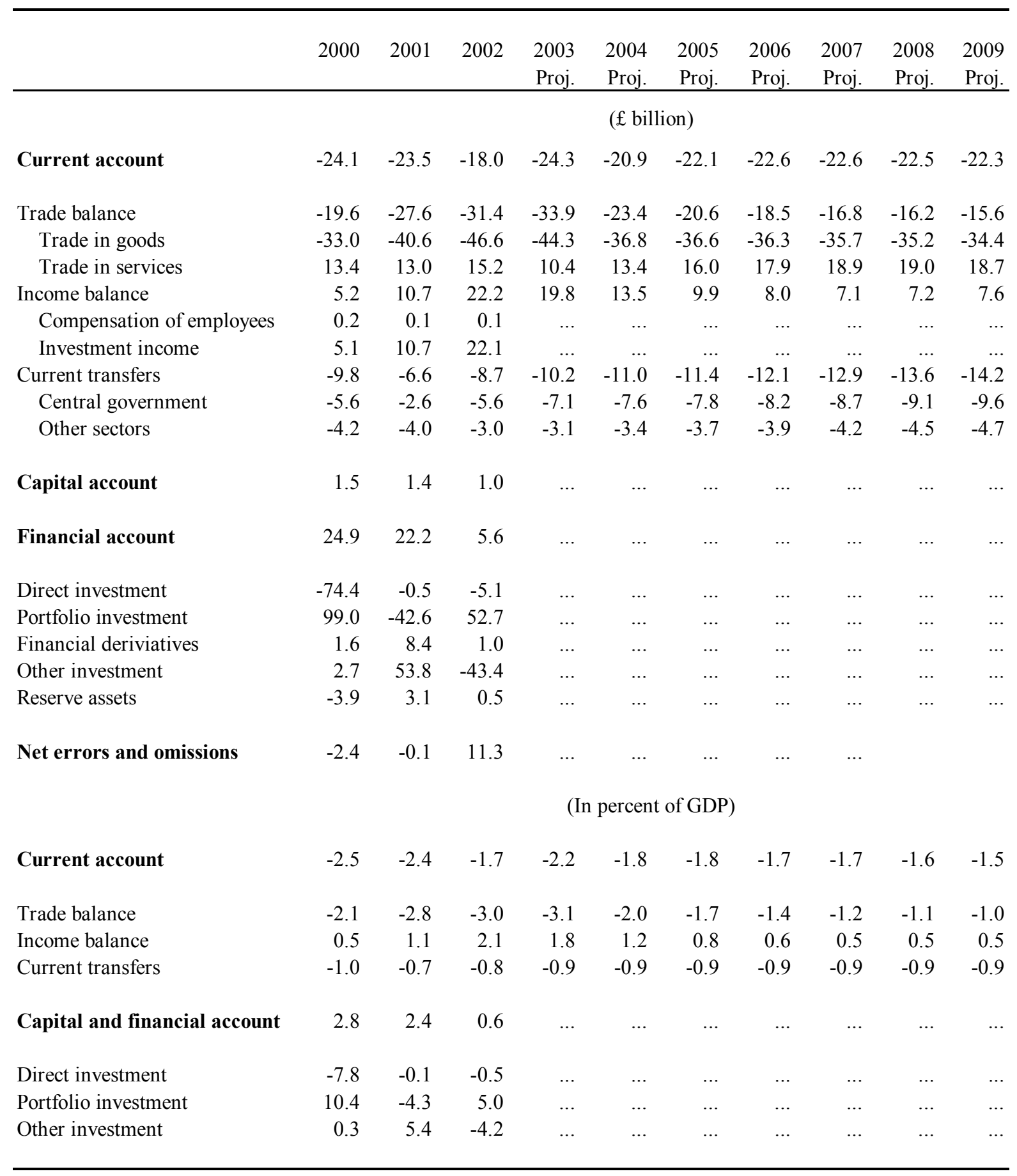

Sources: Office of National Statistics (ONS) and staff projections. 
Table 4. United Kingdom: Medium-Term Scenario

(Percentage change, unless otherwise indicated)

\begin{tabular}{|c|c|c|c|c|c|c|c|c|c|c|}
\hline & 2000 & 2001 & 2002 & 2003 & 2004 & 2005 & 2006 & 2007 & 2008 & 2009 \\
\hline Real GDP & 3.8 & 2.1 & 1.7 & 2.1 & 3.1 & 2.6 & 2.6 & 2.6 & 2.4 & 2.3 \\
\hline Real domestic demand & 3.8 & 2.7 & 2.8 & 2.5 & 3.4 & 2.4 & 2.5 & 2.5 & 2.3 & 2.3 \\
\hline Private consumption & 4.6 & 3.1 & 3.4 & 2.5 & 3.2 & 2.4 & 2.4 & 2.4 & 2.2 & 2.1 \\
\hline Government consumption & 1.9 & 1.7 & 2.7 & 1.5 & 2.5 & 2.5 & 2.5 & 2.5 & 2.4 & 2.2 \\
\hline Fixed investment & 3.6 & 3.6 & 1.8 & 2.3 & 4.6 & 2.7 & 3.0 & 3.2 & 2.9 & 2.8 \\
\hline Public & 6.3 & 12.0 & 8.3 & 23.8 & 22.2 & 6.1 & 5.9 & 5.6 & 4.2 & 3.7 \\
\hline Residential & 0.4 & 1.3 & 15.8 & 10.0 & 6.4 & 1.3 & 0.9 & 1.3 & 1.4 & 1.4 \\
\hline Business & 3.9 & 3.3 & -1.8 & -2.0 & 1.5 & 2.5 & 3.1 & 3.2 & 3.0 & 3.0 \\
\hline Stocks 1/ & -0.1 & -0.2 & -0.1 & 0.2 & 0.1 & 0.0 & 0.0 & 0.0 & 0.0 & 0.0 \\
\hline External balance 1/ & -0.1 & -0.6 & -1.3 & -0.7 & -0.1 & 0.0 & 0.0 & 0.0 & 0.0 & 0.0 \\
\hline Exports & 9.4 & 2.5 & -0.4 & -2.0 & 5.5 & 6.1 & 5.9 & 5.8 & 5.5 & 5.3 \\
\hline Imports & 9.1 & 4.5 & 4.0 & 0.4 & 5.2 & 5.1 & 5.3 & 5.2 & 5.0 & 4.8 \\
\hline Current account 2/ & -2.5 & -2.4 & -1.7 & -2.2 & -1.8 & -1.8 & -1.7 & -1.7 & -1.6 & -1.5 \\
\hline \multicolumn{11}{|l|}{ Inflation } \\
\hline CPI 3/ & 0.8 & 1.2 & 1.3 & 1.3 & 1.5 & 1.8 & 2.0 & 2.0 & 2.0 & 2.0 \\
\hline \multicolumn{11}{|c|}{ Employment and productivity } \\
\hline $\begin{array}{l}\text { Employment } \\
\text { Average unemployment }\end{array}$ & 1.1 & 0.8 & 0.7 & 0.9 & 0.9 & 0.5 & 0.5 & 0.5 & 0.2 & 0.2 \\
\hline rate $4 /$ & 5.5 & 5.1 & 5.2 & 5.0 & 5.0 & 5.0 & 4.9 & 4.9 & 4.9 & 4.9 \\
\hline Productivity $5 /$ & 2.4 & 1.1 & 1.4 & 1.7 & 2.0 & 2.0 & 2.1 & 2.1 & 2.1 & 2.1 \\
\hline
\end{tabular}

Sources: Office for National Statistics; and IMF staff projections.

1/ Contribution to the growth of GDP.

2/ In percent of GDP.

3/ CPI corresponds to the EU-standard harmonized price index. Until December 2003, the inflation target was 2.5 percent for RPIX inflation. The latter was 2.1, 2.2, 2.6 for 2001, 2002 and 2003 respectively.

4/ In percent of labor force; based on Labor Force Survey.

5/ Whole economy. 


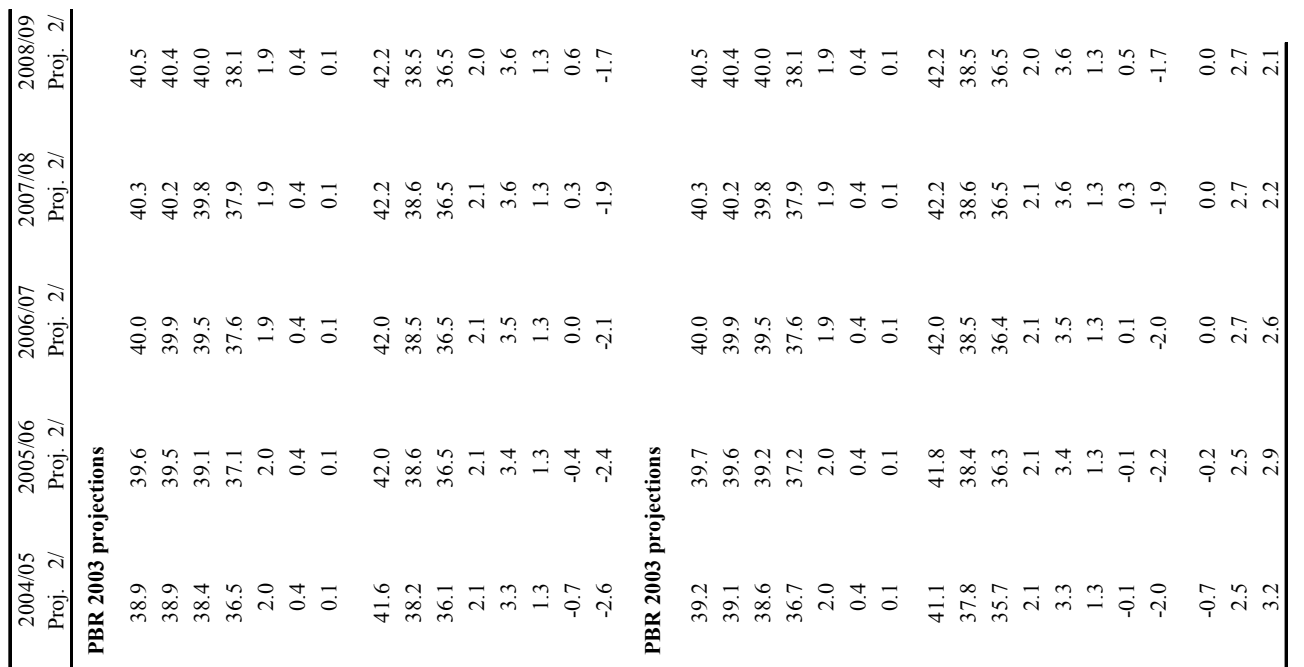

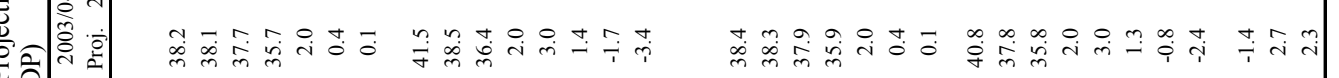

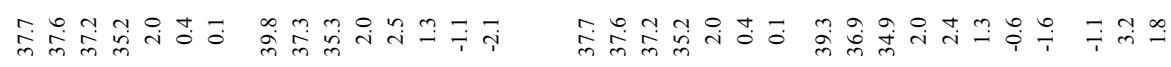

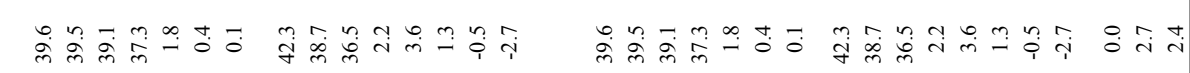

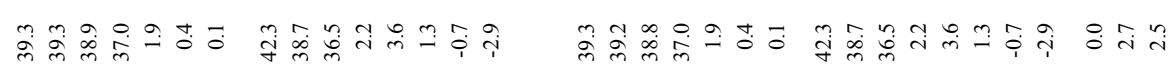

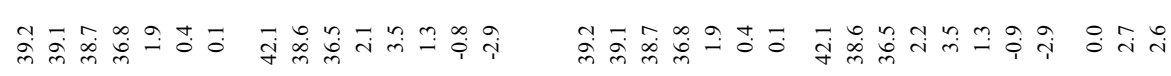

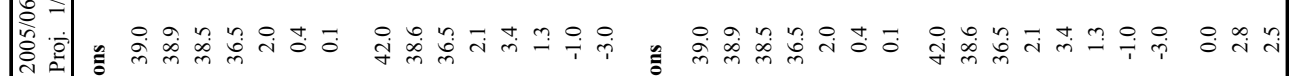

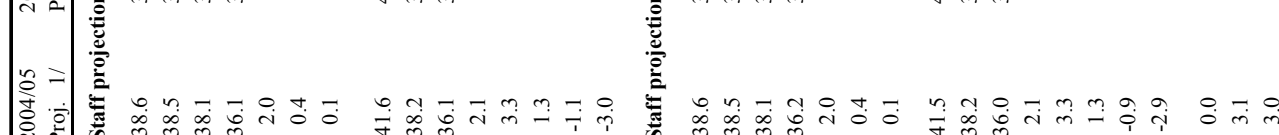

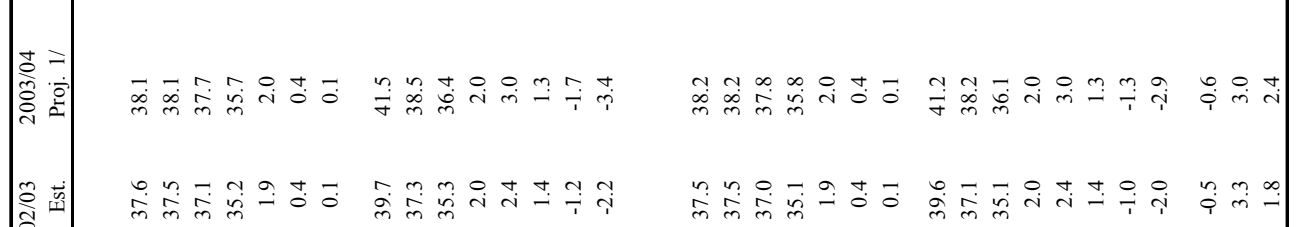

กั่

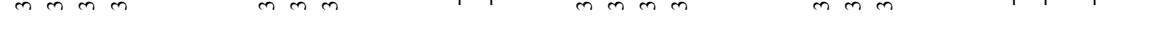

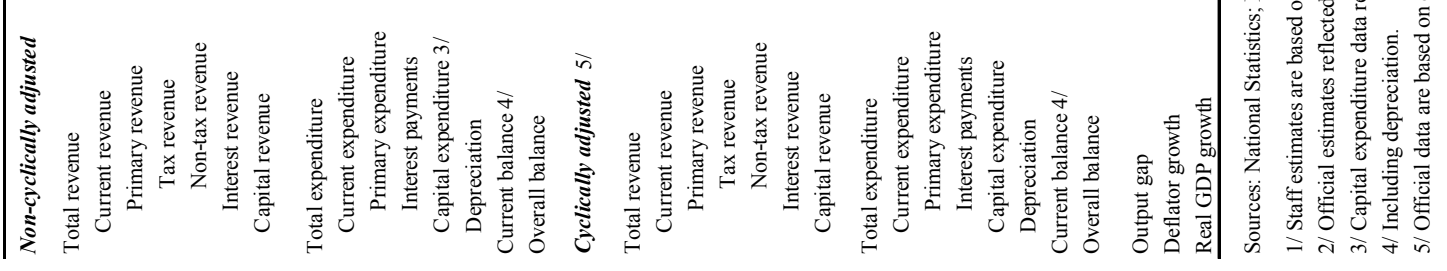




\section{United Kingdom: Basic Data}

Demographic and other data:

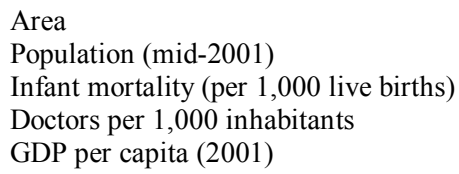

Composition of GDP in 2002, at current prices

Private consumption

Public consumption

Total investment (including stockbuilding)

Total domestic demand

Exports of goods and services

Imports of goods and services

GDP at market prices (average estimate)

Selected economic data

Output and unemployment:

Real GDP (at market prices, average estimate)

Manufacturing production

Unemployment (in percent)

Earnings and prices:

Average earnings in manufacturing

CPI inflation (harmonized price index)

M0 (end of period)

M4 (end of period)

3-month Interbank rate

10 -year government bond yield

Fiscal accounts (In percent of GDP): 4/

General government balance

Public sector balance

Public sector net debt

Balance of payments:

Current account balance

(In percent of GDP)

Trade balance

Exports

Imports

Direct investment (net)

Portfolio investment (net)

Reserve assets
Money and interest rates:

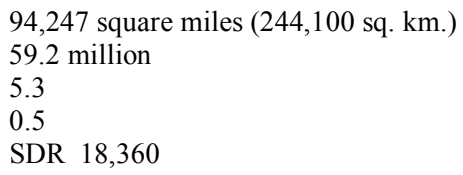

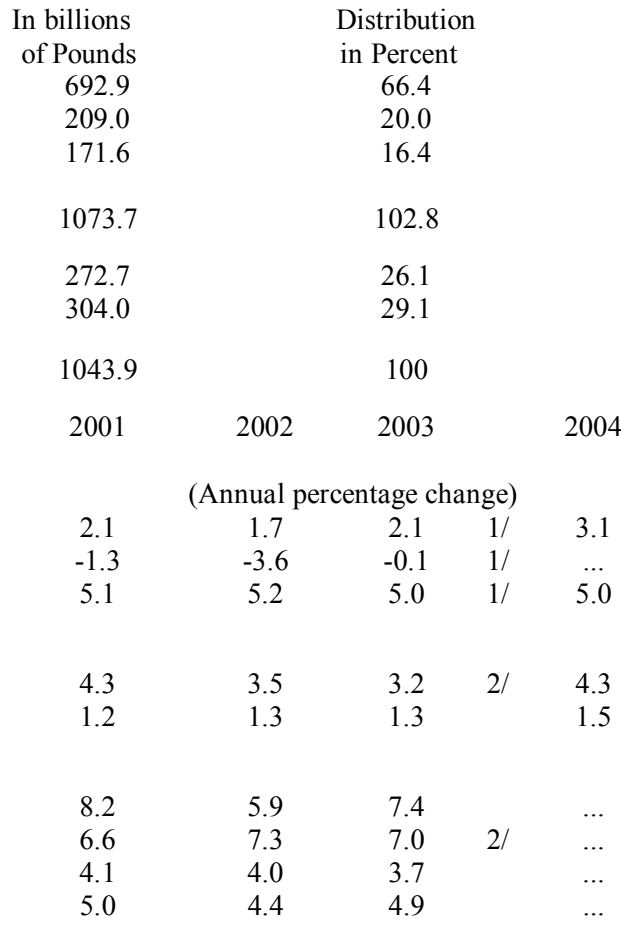

(In billions of pounds sterling)

$\begin{array}{ccccc}0.0 & -2.0 & -3.1 & 3 / & -2.9 \\ -0.1 & -2.2 & -3.4 & 3 / & -3.0 \\ 31.0 & 31.6 & 32.7 & 3 / & 33.9 \\ & & & & \\ -23.5 & -18.0 & -24.3 & 1 / & -20.9 \\ -2.4 & -1.7 & -2.2 & 1 / & -1.8 \\ -27.6 & -31.4 & -33.9 & 1 / & -23.4 \\ 271.7 & 273.3 & 269.4 & 1 / & 266.5 \\ 299.3 & 304.7 & 305.1 & 1 / & 289.9 \\ -0.5 & -5.1 & -3.0 & 1 / & \ldots \\ -42.6 & 52.7 & 44.9 & 1 / & \ldots \\ & & & & \\ 3.1 & 0.5 & 2.3 & 1 / & \ldots\end{array}$

Sources: National Statistics; HM Treasury; and IMF staff estimates.

1/ As of 2003Q3.

2/ As of November 2002.

$3 /$ Includes 2.4 percentage points of GDP in 2000/01 corresponding to the auction proceeds of spectrum licenses.

4/ Fiscal year beginning April 1. 


\section{United Kingdom: Fund Relations}

(As of December 31, 2003)

I. Membership Status: Joined 12/27/1945; Article VIII

II. General Resources Account:

Quota

Fund holdings of currency

Reserve position in Fund

III. SDR Department:

Net cumulative allocation

Holdings

Designation Plan

IV. Outstanding Purchases and Loans:

V. Financial Arrangements:

VI. Projected Obligations to Fund:

VII. Exchange Rate Arrangement:

On September 16, 1992, the U.K. authorities withdrew the pound sterling from the exchange rate mechanism of the European Monetary System and have since maintained a floating regime. As of January 30, 2004 the exchange rate for sterling was \$1.82. In accordance with UN resolutions and EU restrictive measures, the United Kingdom applies targeted financial sanctions under legislation relating to Al-Qaeda or Taliban, and individuals, groups, and organizations associated with terrorism; certain persons associated with the former Government of Iraq and its state bodies; and on specific assets of certain persons associated with to important government functions in Myanmar, the former government of the Republic of Yugoslavia, and Zimbabwe. These restrictions have been notified to the Fund under Decision 144-(52/51).

\section{Article IV Consultation:}

Discussions for the 2002 Article IV consultation were conducted in London during November 21-December 7, 2002. The Staff Report (IMF Country Report No. 03/48) was considered by the Executive Board on February 26, 2003 (EBM/03/16).

\section{FSAP}

The FSAP was completed at the time of the 2002 Article IV Consultations. Preliminary technical discussion was conducted in November 2001. The FSAP work was spread over three missions, which took place in February, May, and July of 2002.
X. Technical Assistance:
None
XI. Resident Representative:
None

\author{
SDR Million \\ $10,738.50$ \\ $6,482.31$
}

,913.07

0.00

None

None

None
\% Quota

60.37

39.64
100.00
13.31

100.00
13.31

\% Allocation 


\section{United Kingdom: Statistical Information}

The United Kingdom maintains high standards of economic data provision. The authorities publish a full range of economic and financial data that is available electronically and have subscribed to the Special Data Dissemination Standard (SDDS). The UK shifted to ESA95 in September 1997. While most of the changes related to the introduction of ESA95 have been implemented, the timetable for the implementation of the reminder of ESA95 extends to 2005. In recent years, the authorities implemented a number of important methodological changes to the national accounts dataset, most of which were related to the adoption of ESA95. In 2003 the authorities introduced further revisions reflecting a shift to annual chainlinking, corrections for import fraud, and revisions in some volatile construction data. As a result of these revisions, the level of GDP was revised upwards, notably during 1999-2000 and the first half of 2003. 

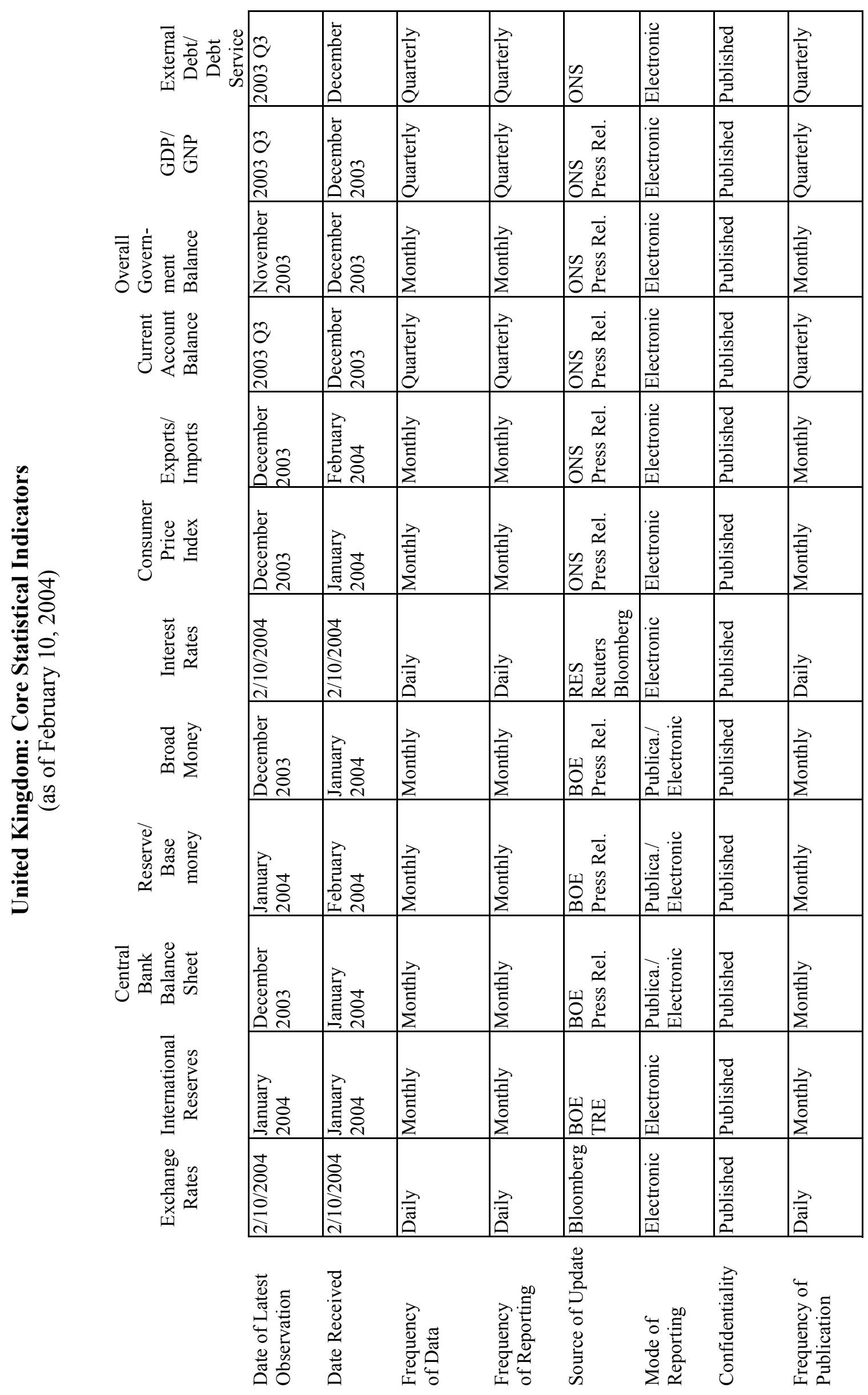


\section{United Kingdom: Sustainability Exercise}

\section{Fiscal sustainability}

The analysis for the United Kingdom, conducted using of the standard template ${ }^{14}$ shows that the rise in public debt is unlikely to cause financing difficulties over the next few years, given that public sector debt starts from a low level and increases only slowly over time.

In the baseline scenario assuming that no policy action is taken, the public debt-to-GDP ratio grows from about $32 \frac{3}{4}$ percent of GDP in 2003/04 to over 381/2 percent of GDP in 2008/09, given the staff projection that the primary balance remains in deficit during this period (Table A1). ${ }^{15}$ This rise in the public debt ratio is unlikely to create debt management, given that it is relatively slow and from a level that is one of the lowest in the OECD. Nonetheless, the stabilization of the public debt ratio would eventually require an improvement of the primary balance, under the assumption that overtime the average interest rate on public debt will exceed the GDP growth rate.

In the alternative scenarios, the public debt-to-GDP ratio evolves similarly to the baseline. Only Scenario A1 shows a decline in the debt ratio, mainly reflecting the assumption (consistent with the historical average) that the primary balance is in surplus. Scenario A3 indicates a slightly larger increase in the debt ratio (to about $393 / 4$ in $2008 / 09$ ), consistent with the assumption of lower growth in 2004.

Even in the extreme (bound test) scenarios, the debt ratio stays below 50 percent of GDP in most cases. Its worst deterioration - to about 501/4 percent in 2008/09 - is in the case when the primary balance is at its historical average minus two standard deviations (Scenario B3).

\section{External sustainability}

External debt sustainability does not appear to be an issue in the United Kingdom; the UK net investment position has remained in the small negative range of 3-5 percent of GDP in 2000-02 and more recently close to balance, partly reflecting large investment abroad by UK oil companies' foreign subsidiaries (Table A2). Recent increases in oil prices have prompted greater earnings from overseas operations, contributing to an improvement in the current account balance. The level of gross external debt is much higher but this reflects the role of London as an international financial center (Table A3). The FSAP concluded in February 2003 has also found that the large financial operations associated with the role of London as international financial center do not pose a systemic risk to the domestic financial system (Table A3). Table A3 provides a summary set of external and financial vulnerability indicators as well.

\footnotetext{
${ }^{14}$ See Public Information Notice No. 02/69 and “Assessing Sustainability,” IMF, 5/28/2002.

15 The debt-to-GDP ratio would also grow over time under the authorities' projection (to about 351/2 percent of GDP in FY2008/09).
} 


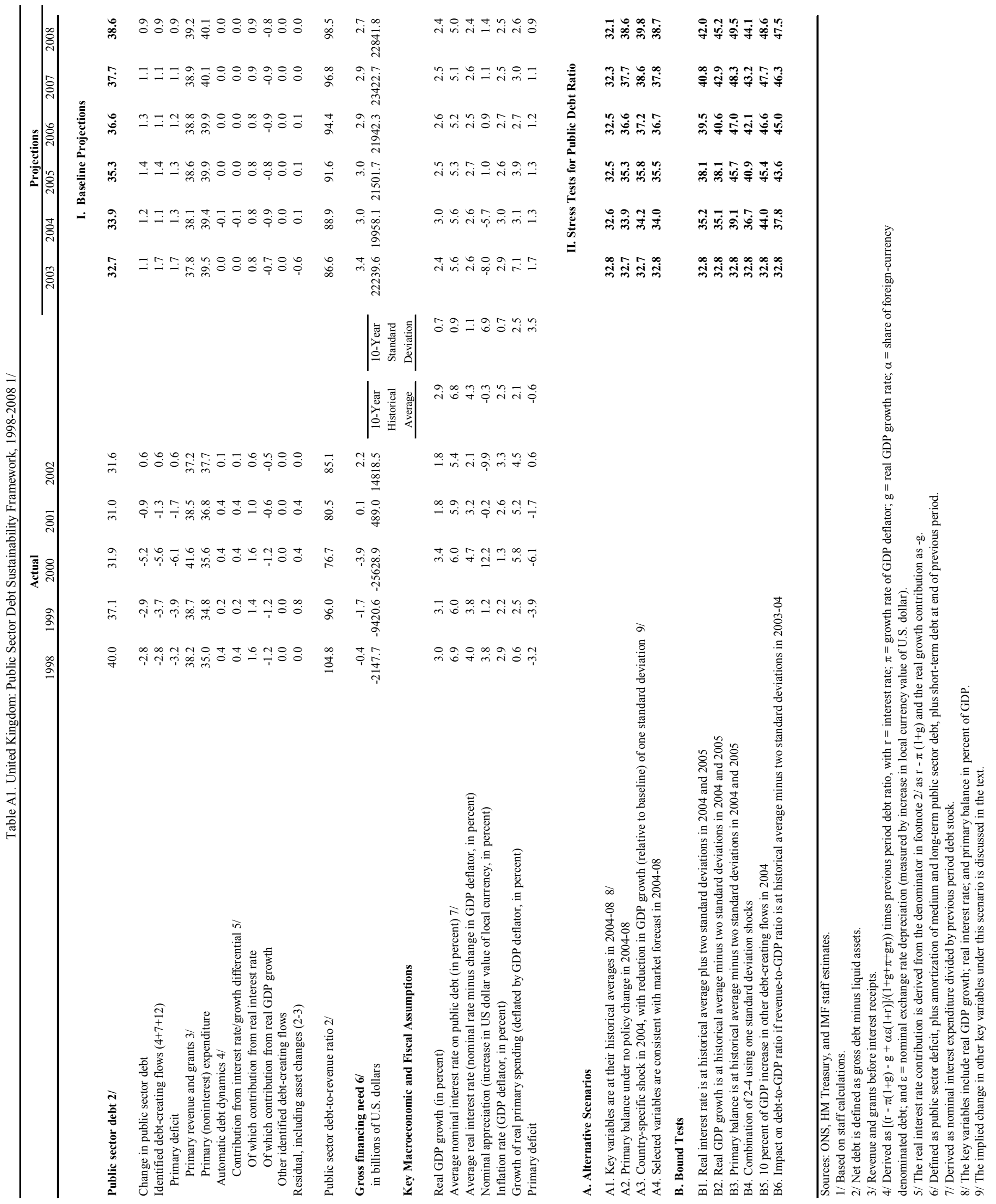


Table A2. United Kingdom: Net Investment Position 1/

(Percent of GDP)

\begin{tabular}{|c|c|c|c|c|c|c|}
\hline & 1998 & 1999 & 2000 & 2001 & 2002 & 2003Q3 \\
\hline Assets & 248 & 268 & 313 & 323 & 300 & 327 \\
\hline Direct investment abroad & 35 & 47 & 64 & 63 & 55 & 60 \\
\hline Portfolio investment abroad & 82 & 93 & 95 & 95 & 82 & 87 \\
\hline Other investment abroad & 129 & 125 & 151 & 162 & 160 & 177 \\
\hline Reserve assets & 3 & 2 & 3 & 3 & 2 & 2 \\
\hline Liabilities & 264 & 275 & 317 & 326 & 305 & 328 \\
\hline Direct investment in the UK & 25 & 28 & 33 & 38 & 35 & 35 \\
\hline Portfolio investment in the UK & 81 & 92 & 105 & 96 & 86 & 92 \\
\hline Other investment in the UK & 158 & 156 & 179 & 191 & 184 & 200 \\
\hline Net investment position & -16 & -8 & -4 & -3 & -5 & -1 \\
\hline Direct investment & 10 & 20 & 31 & 25 & 20 & 25 \\
\hline Portfolio investment & 1 & 1 & -10 & -1 & -4 & -5 \\
\hline Other investment & -30 & -31 & -28 & -29 & -24 & -23 \\
\hline Reserve assets & 3 & 2 & 3 & 3 & 2 & 2 \\
\hline $\begin{array}{l}\text { Net investment position, } \\
\text { excluding direct investment }\end{array}$ & -26 & -27 & -35 & -28 & -25 & -26 \\
\hline
\end{tabular}

Source: Office of National Statistics.

1/ Data correspond to the end of the indicated period. They are expressed as percent of the cumulated GDP of the four quarters ending on that date. 
Table A3. United Kingdom: Indicators of External and Financial Vulnerability (In percent of GDP, unless otherwise indicated)

\begin{tabular}{|c|c|c|c|c|c|c|c|}
\hline & 1998 & 1999 & 2000 & 2001 & 2002 & $20031 /$ & as of: \\
\hline \multicolumn{8}{|l|}{ External indicators } \\
\hline Exports (annual percentage change, in U.S. dollars) & 0.0 & 1.3 & 4.8 & -3.3 & 4.6 & 0.7 & 2003Q3 \\
\hline Imports (annual percentage change, in U.S. dollars) & 4.1 & 4.2 & 5.4 & -0.8 & 5.9 & 3.4 & 2003Q3 \\
\hline Terms of trade (annual percentage change) & 1.2 & -1.5 & -2.2 & -0.8 & 2.9 & 0.0 & 2003Q3 \\
\hline Current account balance & -0.4 & -2.7 & -2.5 & -2.4 & -1.7 & -2.1 & 2003Q3 \\
\hline Capital and financial account balance & 0.3 & 2.4 & 2.8 & 2.4 & 0.6 & 1.5 & 2003Q3 \\
\hline Of which: Foreign direct investment (net) & -3.3 & -7.7 & -7.8 & -0.1 & -0.5 & -0.6 & 2003Q3 \\
\hline Portfolio investment (net) & -1.3 & 10.3 & 10.4 & -4.3 & 5.0 & 5.5 & 2003Q3 \\
\hline Other investment (net) & 5.2 & -0.6 & 0.3 & 5.4 & -4.2 & -3.1 & 2003Q3 \\
\hline Net errors and omissions & 0.1 & 0.3 & -0.2 & 0.0 & 1.1 & 0.5 & 2003Q3 \\
\hline Official reserves (in billions of U.S. dollars, end of period) 2/ & 37.3 & 41.8 & 48.2 & 40.4 & 42.8 & 46.0 & \\
\hline Central bank net foreign assets (in billions of U.S. dollars) & 10.8 & 12.9 & 6.5 & 9.1 & 12.7 & 15.8 & \\
\hline Foreign assets of banking institutions (in billions of U.S. dollars) & 1895 & 1835 & 2150 & 2216 & 2500 & 2995 & 2003Q3 \\
\hline Foreign liabilities of banking institutions (in billions of U.S. dollars) & 1857 & 1826 & 2140 & 2243 & 2593 & 2988 & 2003Q3 \\
\hline Exchange rate against U.S. dollar (period average) & 1.66 & 1.62 & 1.52 & 1.44 & 1.50 & 1.63 & \\
\hline \multicolumn{8}{|l|}{ Financial markets indicators } \\
\hline Public sector net debt & 40.1 & 37.9 & 32.6 & 31.4 & 31.4 & 32.0 & 2003Q3 \\
\hline 3-month T-bill yield & 6.9 & 5.1 & 5.9 & 4.8 & 3.9 & 3.6 & Nov, 03 \\
\hline 3-month T-bill yield (real) 3/ & 4.1 & 3.3 & 2.9 & 4.1 & 0.9 & 1.0 & Nov, 03 \\
\hline Change in stock market index FTSE All shares (percent, end of period) & 9.6 & 22.1 & -4.7 & -15.7 & -20.0 & 9.0 & \\
\hline Spread of 3-month T-bill vs. the U.S. (percentage points) & 1.1 & 0.4 & -0.5 & 2.1 & 2.7 & 2.9 & Nov, 03 \\
\hline \multicolumn{8}{|l|}{ Credit indicators 4 / } \\
\hline M4 lending (exc. effect of securitisations and loan transfers) & 7.9 & 9.2 & 12.4 & 8.8 & 10.5 & 11.6 & Nov, 03 \\
\hline \multicolumn{8}{|l|}{ Total lending to individuals } \\
\hline Secured on dwellings & 5.8 & 8.2 & 8.2 & 10.1 & 13.2 & 14.4 & Nov, 03 \\
\hline Consumer credit & 16.5 & 14.5 & 12.2 & 14.0 & 15.1 & 13.0 & Nov, 03 \\
\hline $\mathrm{o} / \mathrm{w}$ Credit card & 21.6 & 17.4 & 19.5 & 18.0 & 16.3 & 14.3 & Nov, 03 \\
\hline M4 lending to private non financial corporations & 6.9 & 5.8 & 12.2 & 7.2 & 6.7 & 8.1 & Nov, 03 \\
\hline Lending to construction sector & 9.5 & 6.6 & 32.7 & 18.7 & 12.3 & 9.1 & Sept, 03 \\
\hline Lending to real estate sector & 14.3 & 15.3 & 27.6 & 25.3 & 21.8 & 20.1 & Sept, 04 \\
\hline Interest rate on personal loans 5/ & 18.0 & 15.4 & 15.7 & 15.9 & 15.0 & 12.8 & Nov, 03 \\
\hline Interest rate on fixed rate mortgages $5 /$ & 6.5 & 7.1 & 6.5 & 5.6 & 5.2 & 5.6 & Nov, 03 \\
\hline Interest rate on time deposits $5 /$ & 5.2 & 4.2 & 4.5 & 2.4 & 2.5 & 1.9 & Nov, 03 \\
\hline \multicolumn{8}{|l|}{ Financial sector risk indicators 6 / } \\
\hline Total loans to assets (percent) & 82.4 & 82.5 & 82.0 & 82.1 & 83.1 & 83.4 & Sept, 03 \\
\hline Total loans to deposits (percent) & 93.1 & 93.5 & 92.9 & 92.2 & 93.8 & 94.3 & Sept, 03 \\
\hline Foreign exchange loans (in US\$bn) & 1515.7 & 1443.5 & 1698.5 & 1789,1 & 2059.5 & 2420.5 & Sept, 03 \\
\hline Share of foreign exchange loans in total lending (percent) & 41.1 & 39.2 & 41.4 & 41.8 & 41.3 & 43.1 & Sept, 03 \\
\hline Deposits in foreign exchange (in US\$bn) & 1768.6 & 1698.7 & 1995.0 & $2,157.4$ & 2699.9 & 3096.7 & Sept, 03 \\
\hline Share of foreign deposits in total deposits (percent) & 55.5 & 54.9 & 57.3 & 57.8 & 57.9 & 58.4 & Sept, 03 \\
\hline Share of foreign denominated liabilities in total liabilities (percent) & 50.7 & 48.5 & 51.5 & 52.5 & 52.8 & 53.7 & Sept, 03 \\
\hline Share of real estate sector in private credit (percent) & 48.2 & 48.6 & 46.9 & 47.5 & 48.8 & 48.9 & Sept, 03 \\
\hline Share of real estate sector in loans to non financial private corporations & & & & & & & \\
\hline (percent) & 33.6 & 35.8 & 34.9 & 41.3 & 48.0 & 50.4 & Sept, 03 \\
\hline Share of non-performing loans in total loans (percent) $7 / 8 / 9$ & 3.2 & 3.0 & 2.5 & 2.6 & 2.6 & 2.2 & Jun, 03 \\
\hline Regulatory capital to risk-weighted assets $8 / 10$ & 13.2 & 14.0 & 13.0 & 13.2 & 12.2 & 12.4 & Jun, 03 \\
\hline Return on assets (before taxes) $8 / 11 / 12$ & 0.8 & 1.0 & 0.9 & 0.5 & 0.9 & 0.5 & Jun, 03 \\
\hline
\end{tabular}

Source: National Statistics; Bank of England; and IMF, International Financial Statistics.

1/ For 2003, cumulative sum of four quarters ending on the specified date, unless otherwise noted.

2 / Including gold, national valuation.

3/ Calculated as 3-month T-bill over actual 12-month RPI inflation in Dec of relevant year.

4/ Twelve-month growth rates.

5/ Weigthed averages for banks and building societies.

6/ Building societies and insurance companies are excluded from this sample. 'Deposits' includes currency, deposits and money market instruments.

7/ The figures for non-performing loans represent the gross value of loans against which specific provisions have been made.

8/ Includes mortgage banks.

9/ NPL's to Total Loans calculated using prospective methodology that will be used for the Financial Soundness Indiactor (FSI) of the same name.

10/ Capital to RWA calculated using prospective methodology that will be used for the Financial Soundness Indiactor (FSI) of the same name.

11/ Return on Assets calculated using prospective methodology that will be used for the Financial Soundness Indiactor (FSI) of the same name.

12/ Return (pre-tax profit) accrues throughout the year, so will be expected to be a lower in June than at end-year. 


\section{INTERNATIONAL MONETARY FUND}

EXTERNAL

Public Information Notice

RELATIONS

DEPARTMENT

Public Information Notice (PIN) No. 04/15

FOR IMMEDIATE RELEASE

March 5, 2004

International Monetary Fund

$70019^{\text {th }}$ Street, NW

Washington, D. C. 20431 USA

\section{IMF Concludes 2003 Article IV Consultation with the United Kingdom}

On March 3, 2004, the Executive Board of the International Monetary Fund (IMF) concluded the Article IV consultation with the United Kingdom. ${ }^{1}$

\section{Background}

The UK has weathered the global slowdown well. After faltering in the wake of the Iraq war, economic activity has staged a strong recovery. Real GDP grew by 2.3 percent in 2003 , with quarterly growth rates rising above trend in the second half. The upswing reflects not only strengthening external conditions but also the continued buoyancy of domestic demand driven by expansionary monetary and fiscal policies, robust increases in house prices and rising household debt. The labor market has been resilient through the downturn, with unemployment at a 30-year low. Inflation, measured by the RPIX remained near its target of 2.5 percent, while CPI inflation has been for some time some 0.6 percentage point below the new target of 2 percent set in December 2003.

In the first increase in three years, the Monetary Policy Committee (MPC) of the Bank of England hiked rates by 25 basis points in November 2003. It then followed through with an additional 25 basis point increase in February this year, taking the policy rate to 4 percent. In doing so, the MPC noted the world economic recovery had become more broadly based, growth in the second half of last year had been above trend and surveys pointed to a pickup in the pace going forward. Further, household spending and borrowing remained resilient and the

\footnotetext{
${ }^{1}$ Under Article IV of the IMF's Articles of Agreement, the IMF holds bilateral discussions with members, usually every year. A staff team visits the country, collects economic and financial information, and discusses with officials the country's economic developments and policies. On return to headquarters, the staff prepares a report, which forms the basis for discussion by the Executive Board. At the conclusion of the discussion, the Managing Director, as Chairman of the Board, summarizes the views of Executive Directors, and this summary is transmitted to the country's authorities.
} 
housing market strong. Continued growth above trend meant inflationary pressures were likely to pick up gradually over the next two years. While CPI inflation is currently below the 2 percent target rate, an increase in rates was necessary to keep it on track to meet the new target in the medium term.

The budget position has swung since $2000 / 01$, from a surplus of $1 \frac{1}{2}$ percent to a projected deficit of $3 \frac{1}{2}$ percent of GDP in 2003/04. The weakening reflects not only cyclical factors but also planned increases in spending to improve public services and unexpected revenue shortfalls attributable in particular to declines from the financial sector since the global equity market bubble burst. The fiscal expansion has been consistent with the UK fiscal framework, based on a golden rule and a sustainable investment rule, because of wide margins accumulated in the late 1990s. With the cyclical upturn, the recovery in financial market activity, improvements in tax collection and rising effective tax rates from the fiscal drag, the deficit is expected to decline, though views differ on the extent to which this will happen in the absence of policy actions.

The Treasury's June 2003 assessment of the five tests for EMU entry concluded that the case for entry was not yet "clear and unambiguous". In reaching this conclusion, the Treasury highlighted the differences in structure of the housing and household debt markets between the UK and the euro area, though there had been significant progress in meeting the conditions for entry since the initial 1997 assessment. To facilitate convergence with the euro area, the government has taken several initiatives, including the adoption of an inflation target formulated in terms of the EU harmonized inflation index and reviews to identify reforms on both the demand and supply sides of the housing market.

\section{Executive Board Assessment}

Directors commended the continued strong performance of the United Kingdom's economy. Growth remained resilient in the face of the global slowdown and has picked up well ahead of most other industrial countries, while inflation remained close to target and unemployment is at record lows. Directors attributed this robust performance to countercyclical monetary and expansionary fiscal policies within well established and transparent policy frameworks, and to structural factors such as high flexibility of labor, product, and financial markets following decades of reform. Directors, however, noted that the buoyancy of domestic consumption has also been fuelled by robust increases in house prices and household debt, which has increased uncertainty on future developments.

Looking ahead, with external conditions improving and domestic demand maintaining its momentum, Directors expected growth to remain strong. The main risk to this outlook stemmed from the possibility of an abrupt adjustment in house prices and a consolidation of household balance sheets, with possibly protracted effects on consumption. Although the monetary and fiscal frameworks lowered this risk, Directors stressed that the possibility of a hard landing in house prices and consumption cannot be ruled out, particularly given 
uncertainties about the distribution of household assets and liabilities. To minimize these risks, prudent macroeconomic policies are needed.

Directors agreed that monetary policy should continue to tighten to facilitate a soft landing scenario. They stressed that there is a strong case for raising rates preemptively given limited slack in the economy, the strength of the ongoing recovery, as well as the ebullience of the housing and household debt markets. They noted that the increased sensitivity of households' debt servicing burden, and the higher uncertainty on the response of consumption to interest rate hikes called for an "early but gradual" strategy of rate increases. In this context, they viewed the November and February rate hikes of 25 basis points as appropriate. Some Directors noted that the implications for monetary policy of rising asset prices were not clearcut. Directors generally agreed that the recent shift in the inflation target from RPIX to CPI seems unlikely to have major implications for the conduct of monetary policy, and were reassured that the reason for the change in the inflation target has been well communicated to the public.

Noting the widening of the fiscal deficit (including in structural terms) over the last three years, Directors concurred that the fiscal deficit needs to decline in the period ahead in order to observe the fiscal rules, strengthen fiscal fundamentals, and support monetary policy during the cyclical upswing. However, many Directors recommended a somewhat larger decline in the fiscal deficit in the medium term than that projected in the November pre-budget report. In the view of these Directors, a larger decline in the deficit is important to provide more room for counter-cyclical fiscal policy and private investment in the future, and to achieve a fiscal balance more consistent with long-term fiscal requirements. To achieve the recommended fiscal adjustment, these Directors recommended that new fiscal measures be adopted. They considered that reliance on cyclical effects and a rebound in revenues from the financial sector may not be sufficient to achieve the desired decline in the deficit. A number of Directors, however, considered the pace of fiscal adjustment projected in the pre-budget report to be appropriate, particularly in view of the low inflation rate and public debt. In any event, Directors urged the authorities to follow developments closely, especially revenue collections, and to take any necessary corrective actions promptly.

Directors in general called for moderating the growth of spending in areas where current plans involve sharp increases. This would limit the risk of inefficiencies and help fiscal consolidation. In this regard, Directors welcomed the continued strengthening of the expenditure management framework, including the special transparency and accountability requirement for public/private partnerships and private finance initiatives to safeguard the comprehensiveness of the budget process and avoid contingent liabilities. However, they recommended that the authorities take further measures to ensure that increased spending is delivering value for money. Moderating the growth rate of spending would allow time to evaluate whether the new framework is working, and to improve it if needed. Some Directors welcomed recent measures to broaden the application of user fees in public services, and they suggested that both efficiency and fiscal adjustment would benefit from further measures in this regard, including in the health care sector. 
Directors agreed that current and future public pension obligations are modest compared with most other European economies. They viewed the authorities' strategy on pensions, centered on increasing the share of pensioners' income from private sources, as appropriate. However, Directors observed that the success of this approach is contingent on private saving increasing enough, and that there are some indications that this has not been the case so far. In this context, Directors saw risks that public pension liabilities could be higher than currently projected. Therefore, Directors welcomed the establishment of an independent Pension Commission, entrusted with assessing the need for further reform, including the potential for introducing compulsory elements to the pension system.

Directors endorsed the authorities' agenda for raising productivity in the United Kingdom, observing that productivity continues to lag behind that in other industrialized countries. Although they viewed the authorities' multi-pronged approach as appropriate, Directors saw a particular need for systematic monitoring and evaluation of ongoing programs in order to allow for retirement of unsuccessful initiatives, the extension of successful ones, and a targeted prioritization over time. A few Directors also emphasized the importance of human capital development.

Directors welcomed the publication of the Treasury's assessment of the five tests for EMU entry, noting its contribution to informing the public debate on this important decision. They also welcomed the initiatives launched by the authorities to follow up on the assessment, especially the reviews of the demand and supply sides of the housing market. Some Directors noted that the change in the inflation target moves the UK monetary framework closer to the EMU framework. Directors considered that the next assessment could be enriched by elaborating on some difficult issues, such as the long-term implications of joining EMU before full convergence is achieved and the potential costs of delaying entry. However, some Directors pointed out that it would be difficult to take a decision on EMU entry based on technical considerations alone.

Directors concurred with the assessment that the United Kingdom's system of financial supervision is sound. They observed that, as reported in the 2002 FSAP, UK banks appear to be sufficiently profitable and well-capitalized to absorb possible macroeconomic shocks without systemic distress. Nevertheless, Directors urged the authorities to be vigilant about the adverse effects of a possible decline in mortgage collateral values. Directors welcomed the ongoing reform of insurance supervision and regulation and noted that, after several years of considerable stress, conditions in the sector had stabilized. They also welcomed the authorities' ongoing efforts in the area of combating money laundering and terrorism financing.

Directors commended the United Kingdom's commitment to promoting trade liberalization, including reforming the Common Agricultural Policy. They encouraged the authorities to continue to use their position in international institutions to reintroduce momentum in the Doha round negotiations, and to increase the effective access of the least developed countries to industrial country markets. Directors welcomed the ongoing increase in official development assistance and encouraged further efforts to achieve the UN target of 0.7 percent of GNP. 
It is expected that the next Article IV consultation with the United Kingdom will be held on the standard 12-month cycle.

Public Information Notices (PINs) are issued, (i) at the request of a member country, following the conclusion of the Article IV consultation for countries seeking to make known the views of the IMF to the public. This action is intended to strengthen IMF surveillance over the economic policies of member countries by increasing the transparency of the IMF's assessment of these policies; and (ii) following policy discussions in the Executive Board at the decision of the Board. The Staff Report for the 2003 Article IV Consultation with the United Kingdom is also available. 
United Kingdom: Selected Economic Indicators

\begin{tabular}{|c|c|c|c|c|c|c|c|c|}
\hline & 1999 & 2000 & & 2001 & 2002 & $\begin{array}{r}2003 \\
\text { Est. }\end{array}$ & & $\begin{array}{l}2004 \\
\text { Proj. }\end{array}$ \\
\hline \multicolumn{9}{|l|}{ Real Economy (change in percent) } \\
\hline Real GDP & 2.8 & 3.8 & & 2.1 & 1.7 & 2.1 & & 3.1 \\
\hline Domestic demand & 3.8 & 3.8 & & 2.7 & 2.8 & 2.5 & & 3.4 \\
\hline CPI (average, harmonized price index) & 1.4 & 0.8 & & 1.2 & 1.3 & 1.3 & & 1.5 \\
\hline Unemployment rate (in percent) $1 /$ & 6.0 & 5.5 & & 5.1 & 5.2 & 5.0 & & 5.0 \\
\hline $\begin{array}{l}\text { Gross national saving (percent } \\
\text { of GDP) }\end{array}$ & 15.1 & 15.0 & & 14.7 & 14.7 & 14.3 & & 14.6 \\
\hline $\begin{array}{l}\text { Gross domestic investment (percent of } \\
\text { GDP) }\end{array}$ & 17.8 & 17.5 & & 17.1 & 16.5 & 16.5 & & 16.4 \\
\hline \multicolumn{9}{|l|}{ Public Finance (fiscal years) 2/ } \\
\hline General government balance & 1.7 & 4.1 & $3 /$ & 0.0 & -2.0 & -3.1 & & -2.9 \\
\hline Public sector balance & 1.7 & 3.9 & $3 /$ & -0.1 & -2.2 & -3.4 & & -3.0 \\
\hline $\begin{array}{l}\text { Public sector cyclically } \\
\text { adjusted balance } 4 /\end{array}$ & 1.7 & 1.3 & & -0.4 & -2.0 & -2.9 & & -2.9 \\
\hline Public sector net debt & 37.1 & 31.9 & & 31.0 & 31.6 & 32.7 & & 33.9 \\
\hline \multicolumn{9}{|c|}{ Money and Credit (end-period, 12-month percent change) } \\
\hline M0 & 11.6 & 4.3 & & 8.2 & 5.9 & 7.4 & & $\ldots$ \\
\hline M4 & 4.3 & 8.2 & & 6.6 & 7.3 & 7.0 & $5 /$ & $\cdots$ \\
\hline Consumer credit & 14.5 & 12.2 & & 14.0 & 15.1 & 13.0 & $5 /$ & $\ldots$ \\
\hline \multicolumn{9}{|l|}{ Interest Rates (year average) } \\
\hline Three-month interbank rate & 6.0 & 5.8 & & 4.1 & 4.0 & 3.7 & & $\ldots$ \\
\hline Ten-year government bond yield & 5.4 & 4.8 & & 5.0 & 4.4 & 4.9 & & $\ldots$ \\
\hline \multicolumn{9}{|l|}{ Balance of Payments } \\
\hline Trade balance (in percent of GDP) & -1.8 & -2.1 & & -2.8 & -3.0 & -3.1 & & -2.0 \\
\hline $\begin{array}{l}\text { Current account balance (in } \\
\text { percent of GDP) }\end{array}$ & -2.7 & -2.5 & & -2.4 & -1.7 & -2.2 & & -1.8 \\
\hline $\begin{array}{l}\text { Reserves (national valuation of gold, } \\
\text { end of period, in billions of SDRs) }\end{array}$ & 30.5 & 37.0 & & 32.2 & 31.5 & 26.5 & & ... \\
\hline
\end{tabular}

Fund Position (as of December 31, 2003)

Holdings of currency (in percent of quota)

60.4

Holdings of SDRs (in percent of allocation)

Quota (in millions of SDRs)

\section{Exchange Rates}

Exchange rate regime 
Present rate (January 30, 2004)

Nominal effective rate $(1995=100) 6 /$

\begin{tabular}{llllll} 
& & & \multicolumn{3}{c}{ US\$ $=£ 0.548$} \\
122.3 & 126.8 & 124.7 & 125.0 & 118.1 & \\
133.7 & 141.0 & 140.7 & 143.4 & 137.7 & $5 /$
\end{tabular}

Real effective rate $(1995=100) 6 / 7 /$

$133.7 \quad 141.0$

$140.7 \quad 143.4$

$\ldots$

$\ldots$

Social Indicators (reference year, and unless otherwise indicated, percentage of EU-15 average in parentheses): GDP per capita (in current PPP US dollars, 2001) : 25,400 (101 percent); Income distribution (ratio of income received by top and bottom quintiles, 1999): 5.5 (4.6); Life expectancy at birth (2001): 75.7 (male) and 80.4 (female); Automobile ownership (1999): 420 per thousand (92.8 percent); CO2 emissions (ton per capita, 2000): 8.0 (106 percent); Population density (2000): 244 inhabitants per sq. km (210 percent).

Sources: National Statistics; HM Treasury; Bank of England; International Financial Statistics; INS; and IMF staff estimates.

1/ ILO unemployment; based on Labor Force Survey data.

2/ The fiscal year begins in April. For example, fiscal balance data for 2002 refers to FY2002/03. Debt stock data refers to the end of the fiscal year.

$3 /$ Includes the auction proceeds of spectrum licenses (2.4 percentage points of GDP) in 2000/01.

4/ Staff estimates.

5/ As of November 2003.

6/ An increase denotes an appreciation.

7/ Based on relative normalized unit labor costs in manufacturing. 


\section{Statement by Tom Scholar, Executive Director for the United Kingdom March 3, 2004}

My authorities are most grateful to staff for an interesting and high quality set of papers, and will take careful note of their comments.

\section{Economic prospects}

The economic fundamentals in the UK remain sound: 45 consecutive quarters of growth, the longest unbroken expansion on record; growth in $2003^{1}$ of $2.3 \%$; inflation at $1.4 \%$, interest rates at $4 \%$, and employment at record levels of over $74 \%$. With a strengthening global economy, growth is forecast (in the 2003 Pre-Budget Report) to be 3\% to 3 $\frac{1}{2} \%$ in 2004 and 2005; and inflation is expected to remain at, or close to, target. As staff note, there are risks: my authorities remain vigilant to these and agree with staff on the need for cautious macroeconomic polices, to which they are fully committed.

\section{Policy framework}

My authorities will continue to set policy on the basis of the policy framework established in 1997, and based on the principles of transparency, responsibility and accountability:

- Fiscal policy set according to two fiscal rules:

○ the Golden Rule - over the cycle, the Government will borrow only to invest;

o the Sustainable Investment Rule - over the cycle, public sector net debt will be held at a stable and prudent level, defined as $40 \%$ or less;

- Monetary policy set by the Bank of England's Monetary Policy Committee (MPC) to meet a symmetric inflation target.

As staff note, the inflation target has been recalibrated to $2 \%$ on the harmonized consumer price index definition. My authorities agree that this is unlikely to have material implications for monetary policy, and are confident that the reasons for, and implications of, the change have been well communicated and are widely understood in the markets, and more broadly. The MPC will remain vigilant and forward-looking to ensure that inflation remains at or near target at all times.

\section{Fiscal policy}

Staff recommend a gradual and predictable strengthening of the fiscal position; a slower rate of growth of public expenditure; and close monitoring of fiscal developments, including corrective actions if needed.

\footnotetext{
${ }^{1}$ On 25 February, National Statistics published revised figures for GDP in 2003: these show annual GDP growth in 2003 of $2.3 \%$ (the previous estimate was $2.1 \%$ ).
} 
My authorities note that the fiscal rules are widely understood by markets and others as the guiding principles of fiscal policy, and have proved very successful in anchoring expectations. The credibility of this framework is key. My authorities will meet the fiscal rules, and - building on the platform established since 1997, with public sector net debt falling from 44\% in 1996-97 to 33\% in 2003-04 - they will entrench not relax their fiscal discipline. And they have announced that the rate of spending growth in the next spending round (this summer) will be lower than in this round.

Fiscal policy will, as usual, be set in the Budget. The latest available projections (in the PreBudget Report) show a gradual reduction in the deficit to $13 / 4 \%$ of GDP; with an average annual surplus on the current budget of $0.2 \%$ over the cycle; and net debt stabilising at $351 / 2 \%$ of GDP. My authorities are thus on track to meet the fiscal rules.

Staff see downside risks to the revenue projections. My authorities are confident about these projections and note that they are based on deliberately cautious assumptions (e.g. growth at the lower end of the forecast range, and trend growth $0.25 \%$ below the neutral view). Furthermore, they note that financial sector incomes are recovering rapidly, suggesting a rebound in tax revenues.

\section{Structural issues}

Staff have rightly noted the legacy of under-investment in public services. Public sector net investment fell by 15\% annually in real terms between 1991-92 and 1996-97 leaving the UK with the lowest level of public investment of any large EU country. To address this, and recognising the importance of public sector infrastructure for private sector productivity, my authorities aim to raise public sector net investment to $2 \frac{1}{4} \%$ of GDP by $2007-08$.

The key issue, however, is not the level of spending but the quality of the public services delivered. My authorities agree with staff on the need to improve efficiency and effectiveness, and have set out a broad agenda for reform, based on five principles:

- clear, measurable, long-term goals, that focus service providers on the outcomes the authorities seek to achieve;

- independent audit and inspection (separating responsibility for setting and monitoring targets);

- maximum local flexibility and discretion to innovate (with additional freedoms and flexibilities as performance improves);

- transparency (through monitoring and reporting publicly against targets, including local and national comparisons).

- efficiency (last year an independent review of efficiency in the public sector was commissioned, and initial work suggests substantial scope for efficiency savings: allocations in the 2004 spending review will be conditional on this).

With reforms based on these principles, and extra resources being channeled to the best performers, my authorities are determined to ensure value for money in public services. 
My authorities agree with staff on the central importance of raising productivity, and have set out a comprehensive programme of microeconomic reform to remove the barriers that prevent markets from functioning efficiently. These measures aim to improve competition, promote enterprise, support science and innovation, raise skills and encourage investment; and they are regularly monitored and assessed.

On membership of the single currency, my authorities published their assessment of the five economic tests in June 2003. They concluded that a clear and unambiguous case for UK membership had not been made and that a decision to join at that time would not be in the national economic interest. The assessment set out a reform agenda to promote convergence and flexibility. Next month's Budget will report on progress on the issues identified, to determine whether a further assessment of the five tests should be undertaken this year. My authorities are grateful for the staff's analysis in the Selected Issues paper, and will study their comments carefully.

My authorities agree with staff's overall assessment of the UK financial system.

\section{Other issues}

My authorities will continue to support trade liberalization, progress under the Doha round, and CAP reform. They will increase ODA to $0.4 \%$ of GDP in 2005-06, and are committed to the target of $0.7 \%$. They are seeking international agreement on a doubling of global aid flows through their proposal for an International Finance Facility. 